\title{
Distribution and numbers of wintering waterbirds in Sweden in 2015 and changes during the last fifty years
}

\author{
Utbredning och antal av övervintrande sjöfåglar $i$ Sverige 2015 och förändringar \\ under de senaste femtio åren
}

LEIF NILSSON \& FREDRIK HAAS

\begin{abstract}
The International Waterfowl Census started in Europe in 1967, in Sweden already in 1966. In Sweden, country-wide surveys of the inshore coastal areas were undertaken in 1971-1973, 2004 and 2015 in addition to the annual sample counts. In 2015, the entire coast between the Norwegian border and the northern part of the Stockholm archipelago was covered. The total estimate was 616000 (excluding seaducks such as Long-tailed duck and scoters), a slight increase since 2004 and a large increase since 1971-1973. Long-term significant increase or little change was recorded for all species but the Longtailed Duck which decreased significantly. The distribution showed marked changes for several species, with

larger proportions being found in the Baltic archipelagos in later years. In all EU the seaducks declined whereas most other species were stable or increased. In four diving ducks an increases in Sweden and other northern areas was balanced by decreasing numbers for countries to the south and southwest. Thus population changes in Sweden could be related to milder winters in the northern part of the wintering area.

Leif Nilsson \& Fredrik Haas, Department of Biology, Biodiversity, Ecology Building, SE-223 62 Lund, Sweden.

E-mail:leifnilsson@biol.lu.se,fredrik.haas@biol.lu.se
\end{abstract}

Received 4 March 2016, Accepted 5 April 2016, Editor: S. Svensson

\section{Introduction}

Coordinated midwinter counts of waterbirds have been undertaken on a European scale since January 1967, when the midwinter counts of the International Waterfowl Census (IWC) were started in a number of countries including Sweden (Atkinson-Willes 1969, Nilsson 1975, Gillisen et al. 2002; see Nilsson 2008 for more references). Before that, Sweden and some other countries had been running specific national programs for a number of years (AtkinsonWilles 1963, Owen et al. 1986, Nilsson 1968, 1976). It was, however, soon realized that international cooperation was needed and accordingly the IWC was initiated by Wetlands International. Some of the major aims of this project are to get population estimates and trends both on a regional and global scale and to map the distribution of the different species. The IWC also aims to provide background information for international agreements relating to management of wetland birds such as the Ramsaar convention and AEWA (African Eurasian Waterfowl Agreement). For general information about IWC and the international results of the Midwinter Counts, see www.wetlands.org.
In Sweden, midwinter counts started one year before the IWC, in January 1966, when a pilot study was carried out (Nilsson 1967). The results of the first forty years of the IWC in Sweden (19672006) have been reported by Nilsson (2008), where details of the early counts are to be found.

In short, the aim during the first years of the counts was to get as complete coverage of as many potential wintering areas of waterfowl as possible (Nilsson 1975). To reach this goal, aerial surveys were organized after a Danish model (Joensen 1968 , 1974) during 1971-1973 eventually covering all inshore areas of south Sweden (more northern areas being ice-covered in winter in those years). However, it was realized that country-wide surveys could not be undertaken every year and the counts were therefore concentrated at covering a careful selection of important sites counted every year for the calculation of annual indices. A fullscale survey of the inshore areas was again organized in 2004, and in 1987-1989 some regions were fully covered (Nilsson 2008). The first countrywide survey of offshore waters was undertaken in 2007-2011 (Nilsson 2012) but extensive boat 


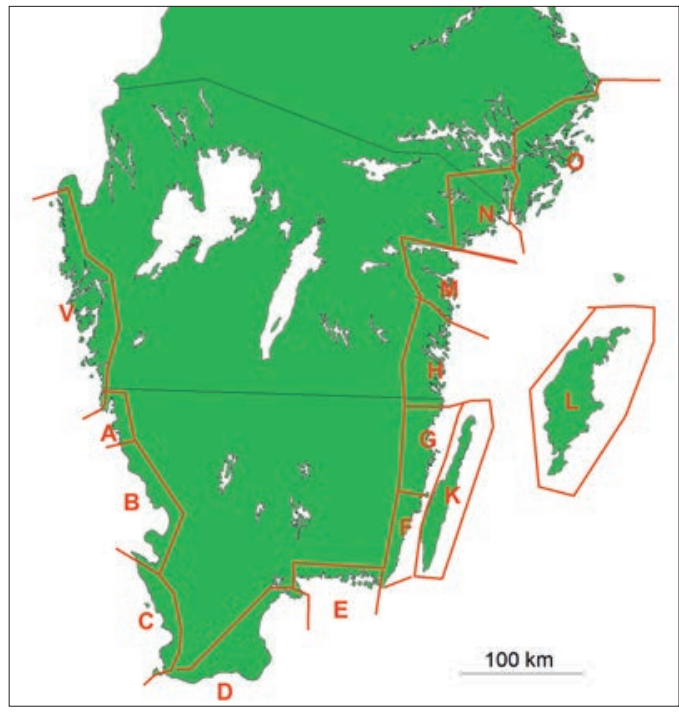

Figure 1. The division of the Swedish coast into regions. For description of the regions, see Table 1 and Nilsson (2008). In the analysis of distribution changes the regions are grouped into four larger units as follows: West $=\mathrm{V}$ and $\mathrm{A}-\mathrm{C}$, South $=\mathrm{D}-\mathrm{G}$, Large Islands $=\mathrm{K}$ and $\mathrm{L}$, and Archipelago $=\mathrm{H}$ and $\mathrm{M}-\mathrm{O}$.

Indelning av den svenska kusten i regioner. För beskrivning av regionerna se Tabell 1 och Nilsson (2008). I analyserna av förändringar $i$ utbredningen har regionerna slagits samman i fyra storregioner enligt följande: Väst $=V$ och $A-C$, Syd $=D-G$, Stora öarna $=K$ och $L$, and Skärgård $=H$ och $M-O$.

surveys were made with the coast guard in some districts during the seventies (Nilsson 1980, 2012).

In 2015, a third country-wide survey of all inshore coastal waters between the Norwegian border and the northern part of the Stockholm archipelago (Figure 1 and Figure 2) was carried out. In this paper we analyse the results of this survey in comparison with the two former country-wide surveys to elucidate any changes in numbers and distribution of different species, especially in relation to climate change (Lehikoinen et al. 2013, PavonJordan et al. 2015). Moreover, we present population trends for a set of species both on a national and regional scale. New analytical tools allow us to include more species than has previously been done (Nilsson 2008). We will also set the Swedish results in a larger perspective as the results from the IWC in the other Baltic countries are available for comparison (cf. Skov et al. 2011).

In the running text throughout this paper we use only English names of bird species. Scientific names will be found in the species accounts and in figures and tables. In Table 2 the species are

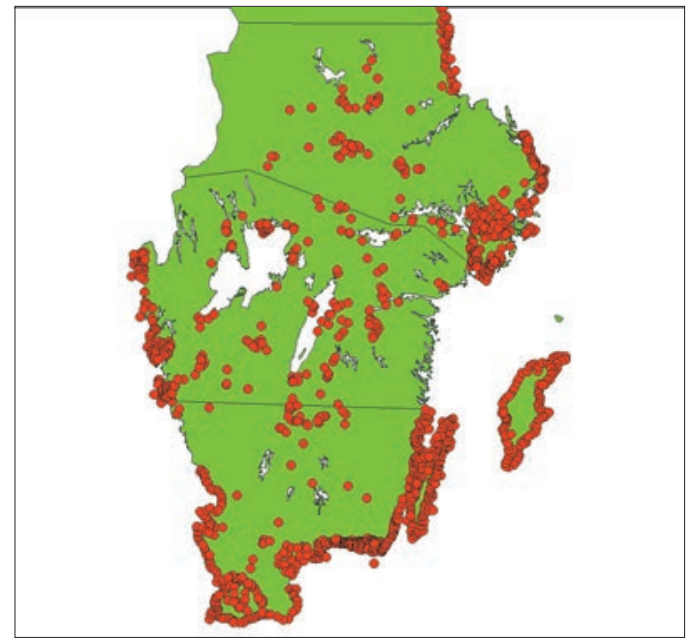

Figure 2. The geographical positions of sites included in the annual midwinter counts at least once during 2006-2015. Det geografiska läget för lokaler inventerade åtminstone vid ett tillfälle $i$ samband med midvinterinventeringarna 2006-2015

listed with their English, scientific and Swedish names. All photos by L. Nilsson.

\section{Material and Methods}

\section{Organization}

The International Midwinter Counts of Waterbirds in Sweden as in the other countries rely on voluntary counters, which cover one or more counting sectors at the specified dates. The counts are organized on the weekend with the Sunday closest to 15 January. Although the observers are encouraged to do the fieldwork during that weekend, it is allowed to do counts the week before and after to avoid bad counting conditions and to get a better coverage.

After the first few exploratory years, the entire Swedish coast was divided into counting sectors with established borders that have been kept the same since then. The strategy has been to have sectors with borders that can easily be recognized in the field. The size of the sectors was chosen to make it possible to cover the entire sector during 
Table 1. Habitat characteristics of the different regions of south Sweden shown in Figure 1.

Habitatdata för de olika regionerna i södra Sverige enligt Figur 1.

\begin{tabular}{lll}
\hline Code & Name & Main habitats \\
\hline V & Bohuslän & Archipelago \\
A & N Kattegat & Open coast with some islands and skerries \\
B & S Kattegat & Open coast with shallow water and bays, some islands \\
C & Öresund & Open coast \\
D & S \& E Scania & Open moraine coast with some beeches \\
E & Blekinge archipelago & Shallow archipelago with many rich bays and inlets \\
F & S Kalmarsund (mainland part) & Moraine coast with some smaller islands \\
G & N Kalmarsund (mainland part) & Open archipelago with relatively few islands \\
H & North Kalmar archipelago & Typical east coast archipelago \\
K & Öland & Open coast with cliffs and large areas of shallow water \\
L & Gotland & Open coast with cliffs and large areas of shallow water \\
M & Östergötland archipelago & Typical east coast archipelago \\
N & Södermanland archipelago & Typical east coast archipelago \\
O & Stockholm archipelago (north to & Typical east coast archipelago \\
& Väddö) & \\
\hline
\end{tabular}

one day. In practice it was normally possible for the counters to cover a number of sectors in a day. For inland Sweden, smaller lakes form one counting sector, whereas the larger lakes were split into several sectors in the same way as the coastal areas. Rivers were in many cases also split into smaller sectors.

During the first years of midwinter counts, the observers freely selected the sites to be covered but from the 1980s the counts for index calculations were standardized and a selection of larger coastal and inland areas (hereafter reference areas) was covered each year to form the basis for trend calculations (Nilsson 2008). These areas were subdivided into the same counting sectors as described above. In addition to the reference areas, counts from smaller sites spread over the country were also collected for the trend-calculations.

For the analysis of the country-wide surveys the coasts of southern Sweden were divided into fourteen regions with similar habitat features (Figure 1, Table 1). These regions were described in detail in Nilsson (2008). For our analysis of changes in the distribution of more common species between the country-wide surveys we have grouped these regions into four larger units (Figure 1). One large unit is called West and includes the regions $\mathrm{V}, \mathrm{A}, \mathrm{B}$ and $C$, i.e. the coast between the Norwegian border and Falsterbo peninsula, thus including Öresund. A second large unit is called South and includes the regions D, E, F and G, i.e. the coast from Fal- sterbo to northern Kalmarsund (mainland coast). A third large unit is called Arhipelago and includes the regions $\mathrm{H}, \mathrm{M}, \mathrm{N}$ and $\mathrm{O}$, i.e. the rest of the eastern coast of southern Sweden through Stockholm archipelago. The forth large unit, called Large Islands, includes the regions $\mathrm{K}$ and $\mathrm{L}$, i.e. the islands of Öland and Gotland.

The Whooper Swan is included in the annual midwinter counts but in recent years it was realized that the species changed habits and was feeding to a higher extent in terrestrial habitats and could therefore not be accurately covered by the midwinter counts (Nilsson 2014). Therefore a special Whooper Swan survey was organized in 1995, and every fifth year since then, simultaneously with the midwinter count. The Whooper Swan survey in 2015, undertaken at the same time as the countrywide survey discussed here is reported separately in this same publication (Nilsson 2016).

\section{Ground counts}

During the ground counts the observer covered the counting sector(s) either by walking the shore line or from vantage points using telescope to cover the water areas, moving between counting points as fast as possible to minimize the effects of movements of the birds. Normally, one observer managed to survey one to several sectors within the same day. 


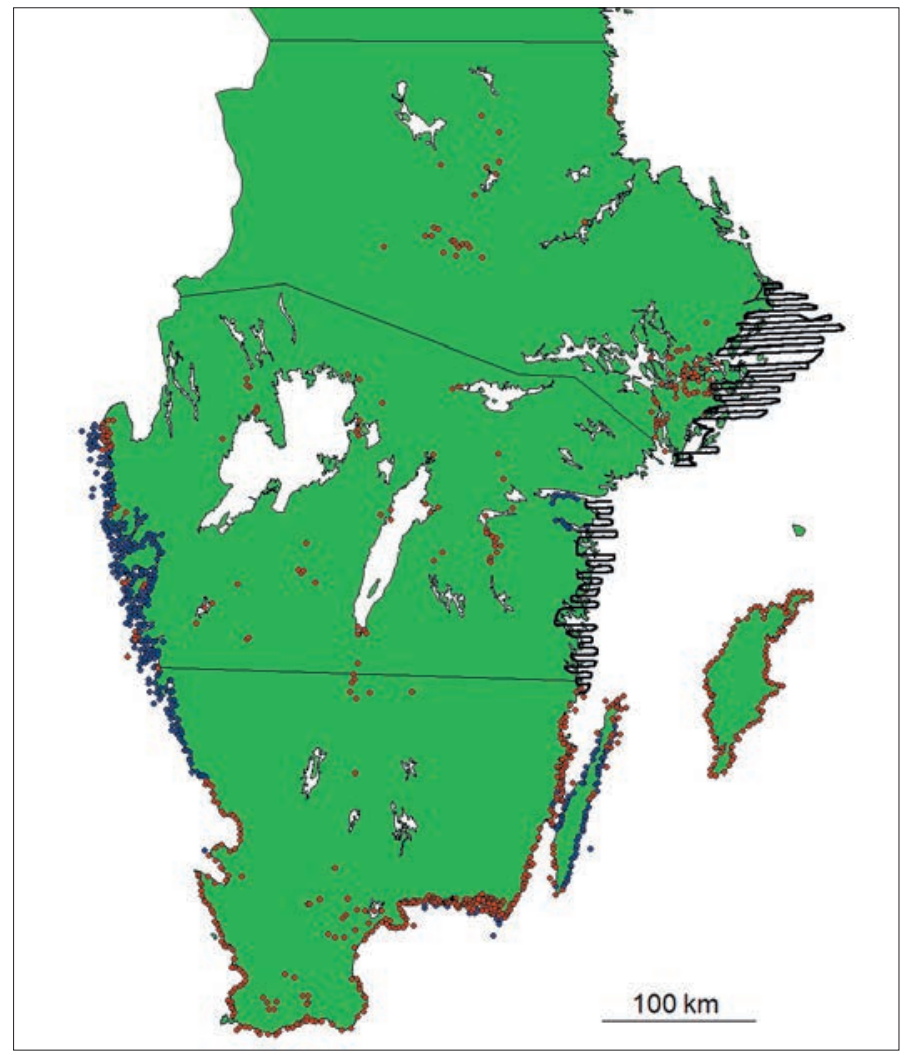

Figure 3. Sites covered at the country-wide survey in January 2015. Red = ground counts, blue $=$ area-based aerial surveys, lines $=$ aerial line transects (for details see Figure 4).

Inventerade lokaler vid den landsomfattande kustinventeringen i januari 2015. Rött = landbaserade inventeringar, blått $=$ flyginventreringar av hela områden och linjer = linjetaxeringar i skärgårdsområden (för detaljer se Figur 4).
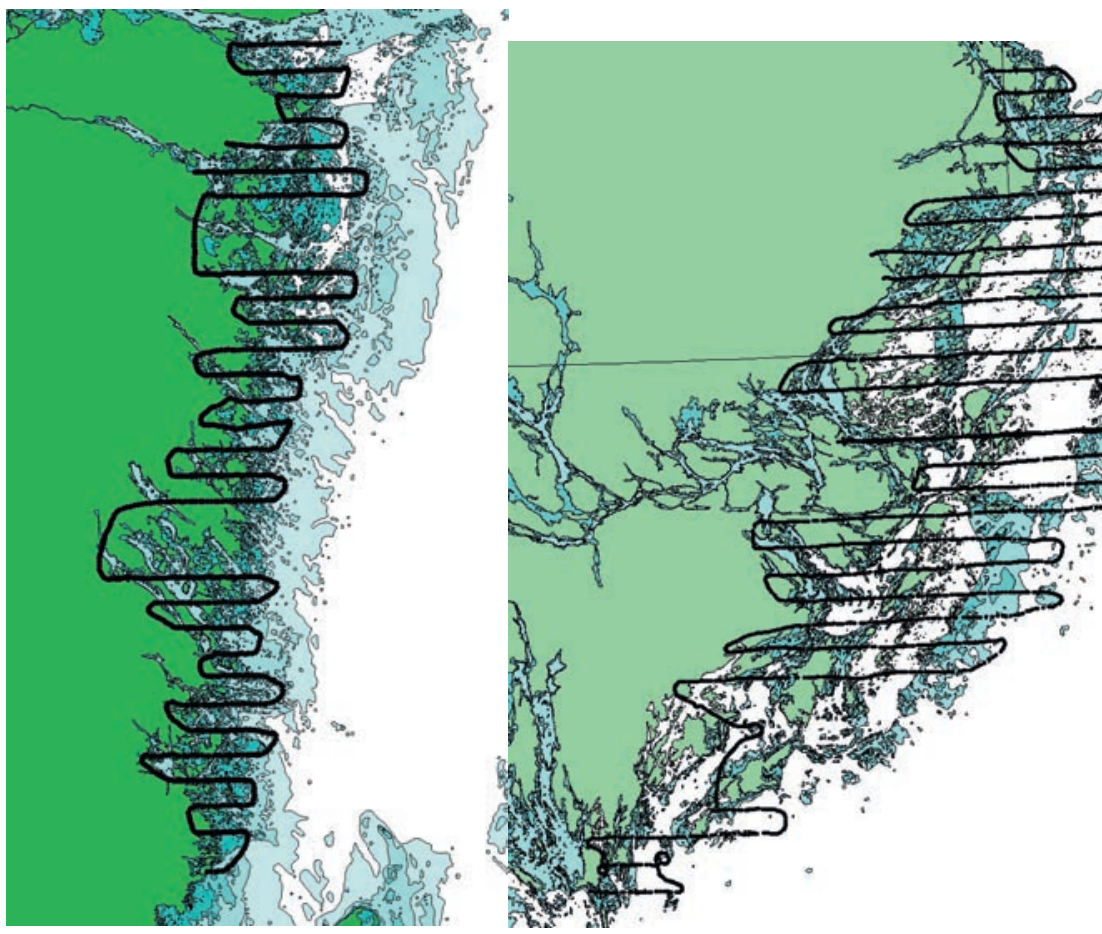

Figure 4. Flight tracks from line transects from the air in the archipelagos of Kalmar län, Östergötland and Stockholm's län in February 2015.

"Flight tracks" från linjetaxeringar med flyg i skärgårdarna i norra Kalmar län, Östergötland och Stockholms län i februari 2015. 
Aerial surveys

For the aerial surveys in 2015 we used a Cessna 337 Skymaster, a twin-engined high-winged aircraft with good visibility. The flying altitude was about $70 \mathrm{~m}$ and the speed $150-180 \mathrm{~km} / \mathrm{h}$, i.e. the slowest possible. Aerial surveys were only carried out in good weather conditions. The flight path was recorded by a GPS taking positions every ten seconds. One to two observers covered each side of the aircraft. All observations and the time of each of the observations were recorded. By using the time the observations were later synchronized with the GPS positions and transferred to a database.

During previous aerial surveys of inshore areas, and during surveys of some areas in this study, the aerial surveys covered the same counting sectors as used in the ground counts. Along open shores the flight path was laid out about $200 \mathrm{~m}$ from the shore, whereas in the archipelagos the different islands were circled so that the entire shallow water area within the sectors could be overlooked from the air. In the 2015 flight survey this method was used on the west coast, in Kalmarsund and along the open coasts of Öland. In contrast to previous aerial surveys there was no ice in the east coast archipelagos, which made the areas to cover too large for this method, so the remaining areas were covered by line transects (Figure 3).

The aerial line-transect method was developed for the offshore surveys (Nilsson 2012). In 2015 census lines were laid out so that all important water areas in the archipelagos could be covered. The distance between the survey lines here was 4 $\mathrm{km}$. Fixed waypoints at the ends of each transect were established and navigation was undertaken with the aid of the GPS of the aircraft. We counted all waterbirds within a main belt extending $200 \mathrm{~m}$ on both sides of the aircraft. This means that we covered a zone $320 \mathrm{~m}$ wide as there was a dead angle below the aircraft. All observations of flocks outside the main belt were recorded as additional observation.

To estimate regional totals for the different species we used the counts within the main belts of the surveys and multiplied the number of observed birds with a factor of 12.5. Each flight transect represent a $320 \mathrm{~m}$ wide sample band through an area which was $2 \mathrm{~km}$ on each side of the aircraft, thus we extrapolated the number of birds by multiplying the number of observed birds with the quota between the width of the study area $(4000 \mathrm{~m})$ and the width of the sample band $(320 \mathrm{~m})$.

The efficiency of aerial surveys of different spe- cies was much studied during the seventies by air/ ground comparisons for different species in different habitats (Nilsson 1975, cf. also Joensen 1974). In these studies marked differences in the survey efficiency were found between species but also between different observers. During inshore surveys in the seventies, in 2004 and in some areas in 2015 the surveys were based on the counting sectors (see above), whereas the aerial surveys of the Swedish offshore waters in 2007-2011 (Nilsson 2012, Skov et al. 2011) as well as the east coast archipelago surveys in 2015 were performed as line transects. However, we do not believe that the use of two different survey methods severely influences the results. Thus, the results from 2015 are fully comparable with previous surveys.

\section{Coverage of counts}

The annual Midwinter Counts cover a sample of counting sectors in the southern part of Sweden (Figure 2). During the last ten years between 644 and 944 counting sectors have been surveyed annually. For further details on the number of sectors covered at the counts see Appendix 1. For analytical reasons the majority of the counting sectors were grouped into 28 reference areas in the late 1980s. Within these reference areas a fixed selection of counting sectors were covered each year, whereas the counting frequency of other counting sectors has varied between years. In some of the reference areas all sectors could not be counted from the ground being hidden behind islands etc.

In the country-wide survey in January 2015, we used a combination of ground counts and aerial surveys to cover the inshore parts of the Swedish coast from the Norwegian border on the west coast to Norrtälje in the northern part of the Stockholm archipelago on the Baltic coast (Figure 3). The areas with open coast, i.e. mainly southern Halland to southern Kalmarsund and Gotland and parts of Öland were covered by ground counts, whereas the rest was covered from the air. Details of the line transects in the east coast archipelagos can be seen from Figure 4. We could not fly the entire Stockholm archipelago, because of military activities in some areas. Moreover it was not possible to cover the archipelagos of the Södermanland county due to lack of flying time in the region. Thus, there are some gaps in the geographical coverage. In all we spent 28.5 flying hours on active counting of waterfowl during the survey.

The coverage of the country-wide survey in 2015 was similar to the country-wide surveys in 
1971 and 2004 (Nilsson 2008). In 1972, 1973, 1987-1989, complete coverage was obtained in some regions (see Tables 3-5, for details see Nilsson 2008). For details on the coverage of the counts in different years, see the annual reports that can be downloaded from the project webpage: http:// www.zoo.ekol.lu.se/waterfowl/index.htm .

\section{Index calculations}

We used the results from the land based counts to calculate population trends for a set of species both on national and regional scale. We based the regional analyses of the coastal regions on the four large areas presented in Figure 1. We did a separate analyses of inland waters. The inland waters were divided into two categories, Inland south and Inland north. We used freeze-up dates for small lakes, $<10 \mathrm{~km}^{2}$, (SMHI 2015a) for the grouping. Inland south included lakes from the area where the freezeup dates normally were after 1 January (Skåne and parts of Bohuslän, Halland and Blekinge) and the other, Inland north, from areas where freeze-up dates were before 1 January (the rest of Sweden). Only a subset of the species analysed at a national level was included in the regional analysis due to limited sample size. At both national and regional level we calculated species population trends based on the maximal available time span for which data were available. This resulted in that the starting year of the time series differed between species, because some species were not surveyed during the first years or they were not abundant enough resulting in too much missing data. On national scale we also calculated species trends for the last ten years (2006-2015). The use of a time span of 10 years is arbitrary, what is important is that it allows us to contrast the long term trends with the population dynamics during recent years.

We used the freely available software package TRIM (http://www.ebcc.info/trim.html) to perform the analysis. TRIM is developed to analyse times series of count data and has the ability to handle missing data using a log-linear Poisson regression method (Pannekoek \& van Strien 2001). The outcome of this procedure is yearly indices.

For each species we present an overall trend estimate, which is the slope of a linear regression where the dependent variable is the logarithm of the indices, and the independent is year (Pannekoek \& van Strien 2001). We run the TRIM model under the assumption that data were serially correlated.

Moreover, for 1971-2015 and 2006-2015, re- spectively, we produced multiple species indices based on the yearly indices that resulted from the TRIM-analysis of all but two of the species $(n=27)$ included in the national TRIM runs. Two species (Gadwall and Black Guillemot) were excluded because of missing data in the early years of the first mentioned time series.

The multiple species index for a given year was calculated by taking the geometric mean of all species' TRIM-indices that year (Gregory et al. 2005). This was then repeated for all years.

\section{Weather and ice conditions}

The wintering waterbird populations around the inshore parts of the Swedish coast are dependent on the availability of open water. In order to characterize the weather conditions of the winters during the study period we have used two different proxies obtained from the Swedish Meteorological and Hydrological Institute (SMHI), the means of monthly mean temperatures for January for ten stations spread over the southern part of Sweden (the areas covered by duck counts) and the annual maximum for the ice-distribution of the Baltic sea and Kattegat (total area: $420000 \mathrm{~km}^{2}$; SMHI 2015b).

Both these indicators clearly show that the winters in general have been milder in south Sweden during the years of midwinter counts. For the temperature there were several January months with low mean temperatures between 1966 and 1987, the latter the coldest January during the whole study period (Figure 5). After 1987, on the other hand, there was only one really cold January, in 2010.

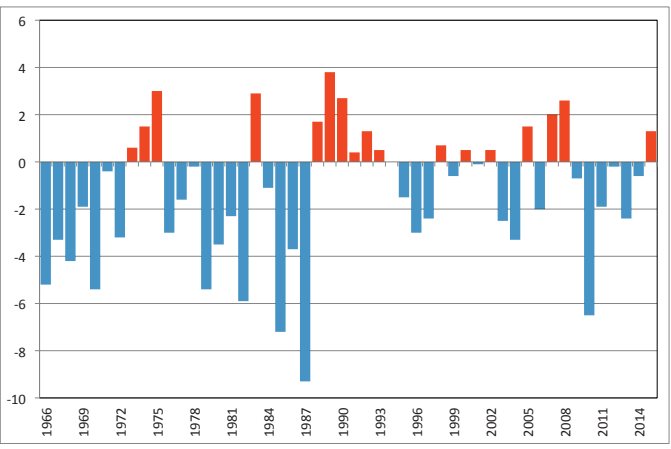

Figure 5. Annual means of monthly mean temperatures for January for ten meteorological stations spread over south Sweden over the area covered by Midwinter Counts. (From the monthly reports of SMHI, the Metrological and Hydrological Institute of Sweden).

Arsmedeltal av de månatliga medeltemperaturerna för januari på tio väderstationer spridda over södra Sverige (Från SMIs månatliga rapporter). 


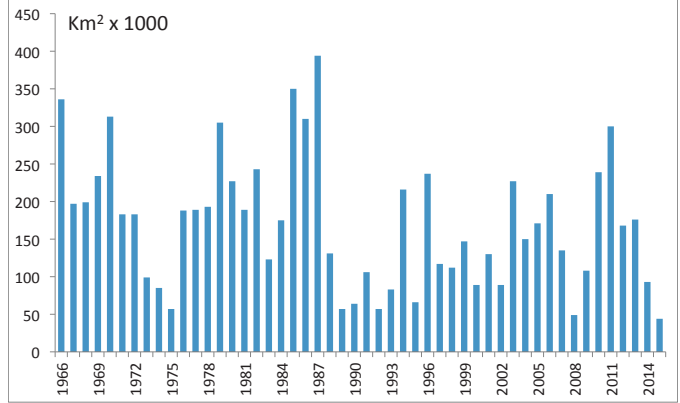

Figure. 6. Maximal extent of ice-coverage in the Baltic Sea during the winters 1966-2015. From SMHI.

Maximal isutbredning $i$ Östersjön under vintrarna 19662015. Från SMHI.

The maximum ice coverage of the Baltic shows a similar picture. Up to 1987 there were six winters with more than $250000 \mathrm{~km}^{2}$ in maximum icecoverage, whereas there was only one such winter in the 28 years after 1987, namely 2011 (Figure 6). The mean temperature for January 2011 was not especially low, but the cold period with much ice came after the midwinter count. Comparing the two periods 1966-1987 and 1988-2015, the mean maximum ice-coverage for the winters were $216000 \mathrm{~km}^{2}$ and $134000 \mathrm{~km}^{2}$, respectively.

To evaluate the influence of ice coverage on bird abundance we correlated the multiple species index with the area of open water $\left(420000 \mathrm{~km}^{2}\right.$ minus area of ice coverage). We did this for three separate time periods; 1971-1987 (low numbers of wintering waterbirds), 1988-2000 (increasing numbers of wintering waterbirds), and 2001-2015 (high numbers of wintering waterbirds).

\section{Abundance and distribution of wintering waterbird populations in 2015}

In January 2015, the total wintering population of different waterbird species in inshore coastal waters of Sweden was estimated to be 616000 , excluding a number of seaduck species (Long-tailed Duck, Velvet Scoter and Common Scoter), which have their main over-wintering areas further out at sea. Their numbers are excluded in Table 2, which shows the estimated numbers of wintering waterfowls in Swedish coastal waters at the three country-wide surveys of Swedish inshore waters, but are included (when fully covered) for some regions in Table 3-5, which show totals for larger areas from the country-wide surveys and from regional surveys with full coverage. Regional totals from the 2015 are found in Appendix 2 and Appendix 3. The total number presented above for 2015 is likely to an underestimate. The area covered in 2015 was the same as in former country-wide coastal surveys but this winter was very mild. Thus, unlike the other years there were significant areas of open coastal water north of the surveyed area.

Full cover counts of Swedish inshore waters were also obtained in 1971 and 2004 (Table 2, Nilsson 2008). Total numbers of birds counted in 2004 was not very different from the totals counted in 2015; about 50000 fewer were found in 2004. There are some differences for the different species, e.g. the Scaup was close to ten times more common in 2015 than in 2004. Other species that were markedly more common in 2015 were Goldeneye, Goosander and Mute Swan, whereas the total count for Tufted Duck was 43000 higher in 2004 than in 2015.

Numbers counted at the coasts during the first country-wide survey in 1971 were appreciably lower for all species and the total was only 174000 .

In addition to the three country-wide coastal surveys discussed above, some regions were also covered fully in other years (see Table 3-5). The number of waterfowl in region $\mathrm{V}$, the archipelago of Bohuslän (Table 3) shows the same general increase as was found in the national totals (Table 2). For the total waterbird fauna, numbers have increased dramatically between 1971 and 2015. The number of wintering waterfowls in this area is more than five times higher today compared to the beginning of the 1970s. The repeated surveys indicate that this increase has been a more or less continuous process, although a slight decline in numbers have occurred between 2004 and 2015, mainly so for Goldeneye, Eider, Mute Swan and Cormorant.

In the southern regions there were no marked changes in the overall numbers of wintering waterfowl between the early seventies and the late eighties, even if there was much variation between years for different species but also in the annual totals (Table 4). On the other hand overall totals more than doubled between the late eighties and the surveys in 2004 and 2015. The overall totals for the last two surveys were similar even if there were quite marked differences for some species.

Very marked changes in the number of wintering waterbirds were found for the archipelagos of the east coast when comparing the three surveys in 1971-1973 with the surveys in 2004 and 2015 (Table 5). Excluding the Long-tailed Duck, that was not covered fully in 2004 and 2015 (with the exception of Stockholm archipelago (region O, Fig- 


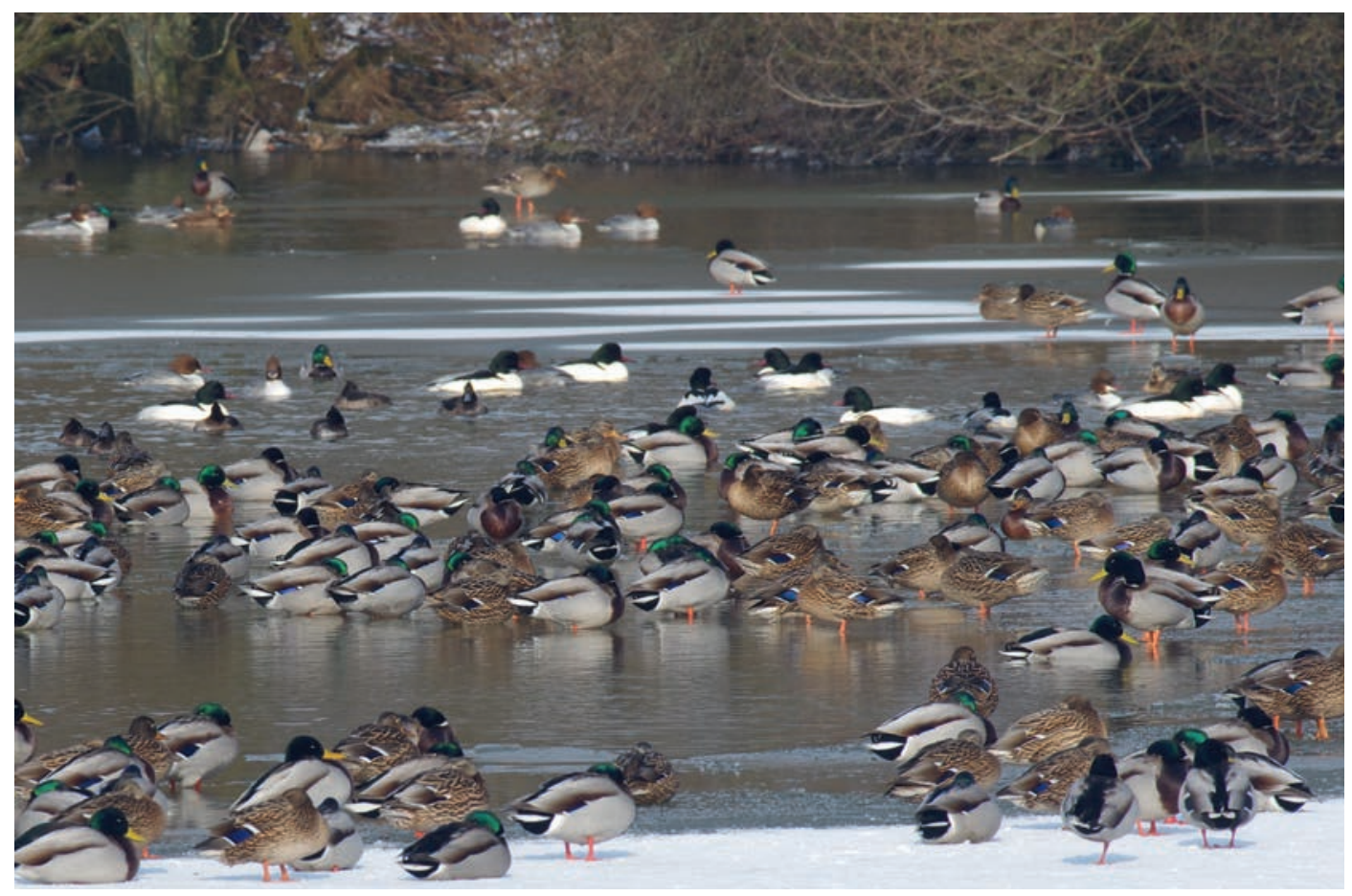

Mallard, Goosander and Tufted Duck

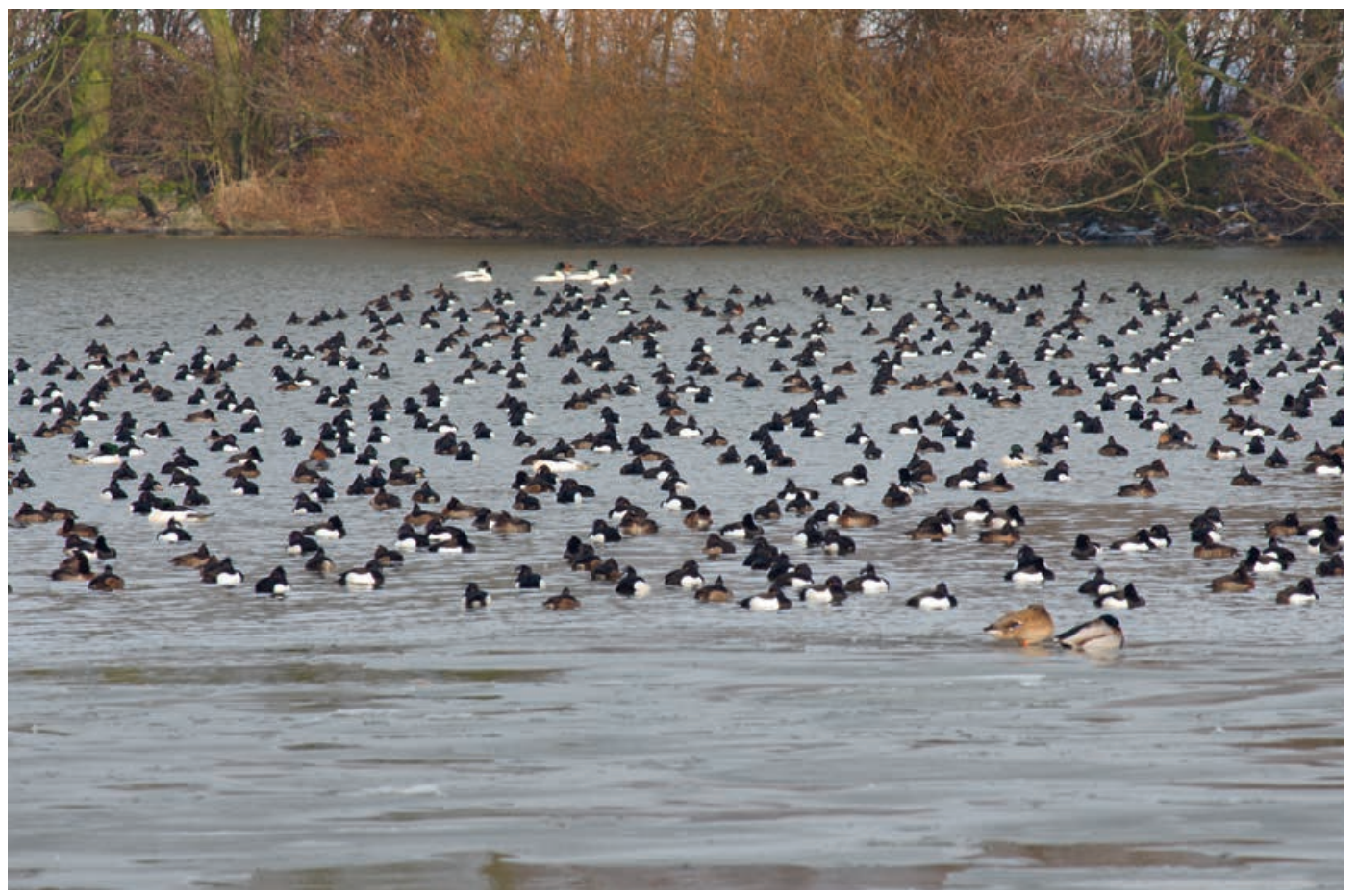

Tufted Duck, Goosander and Mallard 
Table 2. Total estimated wintering populations of different waterbirds species in Swedish coastal waters in 1971, 2004 and 2015. A dash indicates no estimate; some species were not counted in 1971 and for the seaducks offshore data are lacking in all three years.

Uppskattat antal övervintrande individer efter de svenska kusterna för olika sjöfågelarter 1971, 2004 och 2015. Ett streck anger att skattning saknas; några arter inventerades inte 1971 och för de havslevande dykänderna saknas data från de yttre havsområdena.

\begin{tabular}{|c|c|c|c|}
\hline Species $A r t$ & 1971 & 2004 & 2015 \\
\hline Mallard Anas platyrhynchos Gräsand & 29400 & 77800 & 87000 \\
\hline Eurasian Teal Anas crecca Kricka & 7 & 315 & 496 \\
\hline Eurasian Wigeon Anas penelope Bläsand & 3 & 5562 & 8771 \\
\hline Gadwall Anas strepera Snatterand & 4 & 14 & 114 \\
\hline Northern Pintail Anas acuta Stjärtand & 4 & 14 & 25 \\
\hline Northern Shoveler Anas clypeata Skedand & 0 & 1 & 1 \\
\hline Greater Scaup Aythya marila Bergand & 1100 & 3153 & 26850 \\
\hline Tufted Duck Aythya fuligula Vigg & 52197 & 225000 & 182000 \\
\hline Common Pochard Aythya ferina Brunand & 92 & 2660 & 1208 \\
\hline Goldeneye Bucephala clangula Knipa & 17606 & 71872 & 87000 \\
\hline Long-tailed Duck Clangula hyemalis Alfågel & - & - & - \\
\hline Velvet Scoter Melanitta fusca Svärta & - & - & - \\
\hline Common Scoter Melanitta nigra Sjöorre & - & - & - \\
\hline Common Eider Somateria mollissima Ejder & 4537 & 48995 & 51731 \\
\hline Red-breasted Merganser Mergus serrator Småskrake & 2439 & 5334 & 5196 \\
\hline Goosander Mergus merganser Storskrake & 7839 & 18004 & 35000 \\
\hline Smew Mergellus albellus Salskrake & 348 & 3716 & 8007 \\
\hline Shelduck Tadorna tadorna Gravand & 2 & 29 & 112 \\
\hline Mute Swan Cygnus olor Knölsvan & 7281 & 31138 & 50500 \\
\hline Whooper Swan Cygnus cygnus Sångsvan & 1434 & 1485 & 1196 \\
\hline Bewick's Swan Cygnus bewickii Mindre sångsvan & 0 & 0 & 8 \\
\hline Coot Fulica atra Sothöna & 3860 & 15597 & 11198 \\
\hline Cormorant Phalacrocorax carbo Storskarv & 1008 & 11709 & 14258 \\
\hline Shag Phalacrocorax aristotelis Toppskarv & 0 & 0 & 23 \\
\hline Grey Heron Aredea cinerea Gråhäger & - & 495 & 606 \\
\hline Black-throated Diver Gavia arctica Storlom & - & 114 & 36 \\
\hline Red-throated Diver Gavia stellata Smålom & - & 30 & 124 \\
\hline Great Crested Grebe Podiceps cristatus Skäggdopping & - & 4294 & 2726 \\
\hline Red-necked Grebe Podiceps griseigena Gråhakedopping & - & 35 & 20 \\
\hline Slavonian Grebe Podiceps auritus Svarthakedopping & - & 75 & 86 \\
\hline Little Grebe Tachybaptus ruficollis Smådopping & - & 95 & 35 \\
\hline $\begin{array}{l}\text { Total except seaducks } \\
\text { Summa exkl.. havsdykänder }\end{array}$ & 173999 & 569776 & 616112 \\
\hline
\end{tabular}



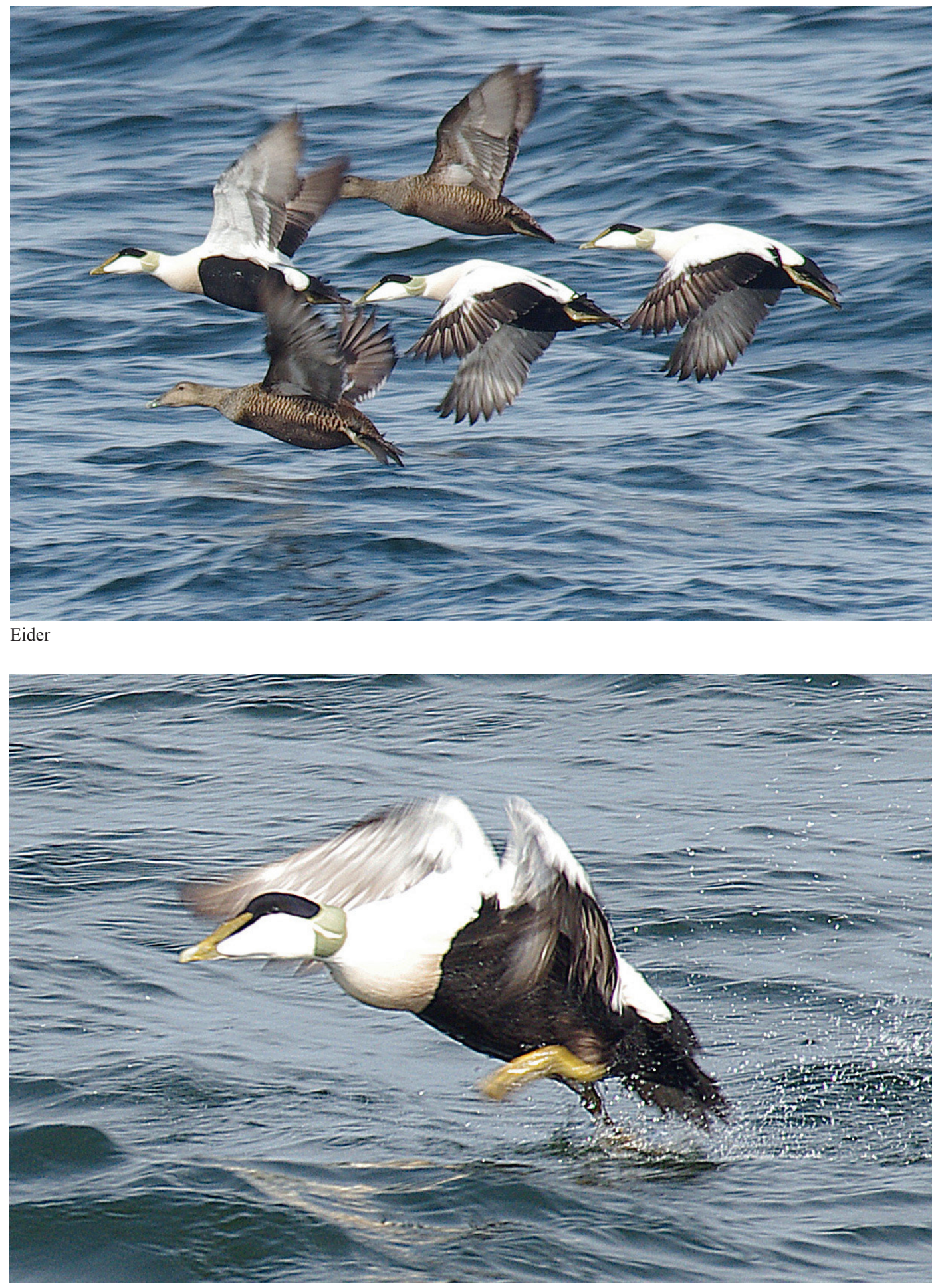

Eider 
Table 3. Total numbers of wintering waterbirds counted in region $\mathrm{V}$, the archipelago of Bohuslän on the west coast (Figure1) at surveys covering the entire province. Species marked with dash for 1971 were not counted during that year.

Antal övervintrande sjöfåglar i region V, Bohusläns skärgård (Figur 1), vid inventeringar som täckte hela landskapet. Arter markerade med streck 1971 inventerades inte det året.

\begin{tabular}{|c|c|c|c|c|c|c|}
\hline Species $A r t$ & 1971 & 1987 & 1988 & 1989 & 2004 & 2015 \\
\hline Anas platyrhynchos & 1083 & 3023 & 4315 & 2333 & 7055 & 2463 \\
\hline Anas crecca & 0 & 0 & 0 & 0 & 11 & 0 \\
\hline Anas penelope & 0 & 0 & 2 & 0 & 1 & 0 \\
\hline Anas strepera & 0 & 1 & 0 & 0 & 1 & 0 \\
\hline Anas acuta & 0 & 0 & 0 & 0 & 0 & 0 \\
\hline Aythya marila & 0 & 0 & 25 & 0 & 10 & 0 \\
\hline Aythya fuligula & 1020 & 4 & 82 & 0 & 328 & 361 \\
\hline Aythya ferina & 40 & 1 & 3 & 0 & 3 & 0 \\
\hline Bucephala clangula & 996 & 1242 & 2967 & 1803 & 13161 & 6822 \\
\hline Clangula hyemalis & 87 & 0 & 0 & 81 & 11 & 7 \\
\hline Polysticta stelleri & 0 & 0 & 0 & 0 & 0 & 0 \\
\hline Somateria mollissima & 2881 & 1918 & 4702 & 5549 & 36582 & 29706 \\
\hline Melanitta fusca & 10 & 0 & 131 & 136 & 13 & 4 \\
\hline Melanitta nigra & 14 & 11 & 56 & 128 & 76 & 80 \\
\hline Mergus serrator & 214 & 427 & 1006 & 1076 & 1313 & 766 \\
\hline Mergus merganser & 114 & 790 & 356 & 66 & 1020 & 539 \\
\hline Mergellus albellus & 0 & 10 & 9 & 0 & 52 & 2 \\
\hline Tadorna tadorna & 0 & 0 & 5 & 1 & 10 & 13 \\
\hline Cygnus olor & 1007 & 1393 & 1680 & 913 & 3287 & 2330 \\
\hline Cygnus cygnus & 167 & 709 & 374 & 230 & 316 & 100 \\
\hline Fulica atra & 40 & 3 & 1 & 0 & 235 & 5 \\
\hline Phalacrocorax carbo & 172 & 1503 & 1601 & 652 & 3438 & 1766 \\
\hline Phalacrocorax aristotelis & - & 0 & 0 & 0 & 0 & 21 \\
\hline Aredea cinerea & - & 0 & 18 & 121 & 99 & 50 \\
\hline Gavia arctica & - & 0 & 28 & 5 & 2 & 0 \\
\hline Gavia stellata & - & 0 & 4 & 1 & 0 & 1 \\
\hline Podiceps cristatus & - & 0 & 2 & 0 & 2 & 3 \\
\hline Podiceps griseigena & - & 0 & 0 & 0 & 2 & 0 \\
\hline Podiceps auritus & - & 0 & 0 & 0 & 5 & 0 \\
\hline Tachybaptus ruficollis & - & 0 & 0 & 2 & 17 & 1 \\
\hline Total Summa & 7845 & 11035 & 17367 & 13097 & 67050 & 45040 \\
\hline
\end{tabular}




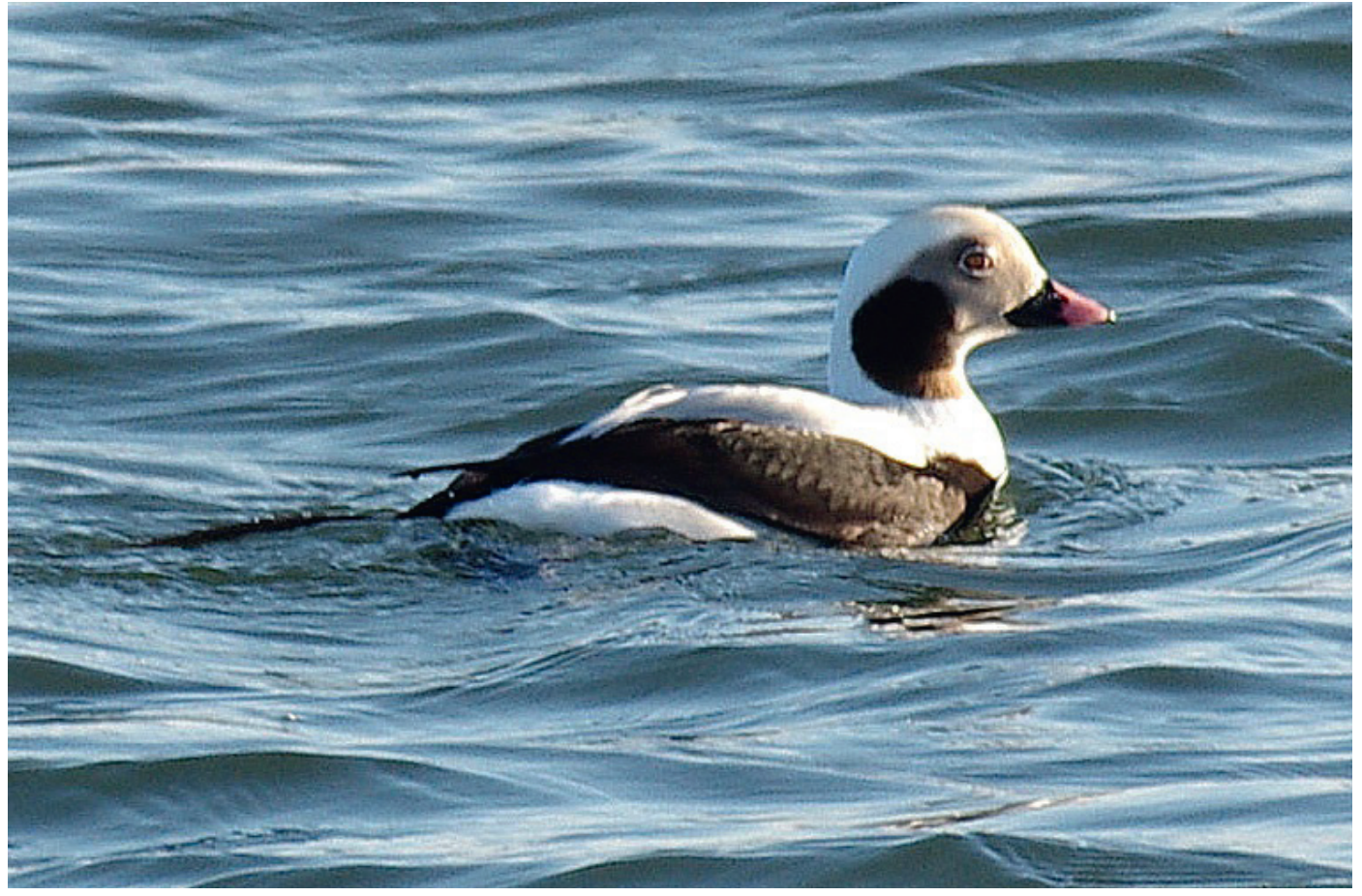

\section{Long-tailed Duck}

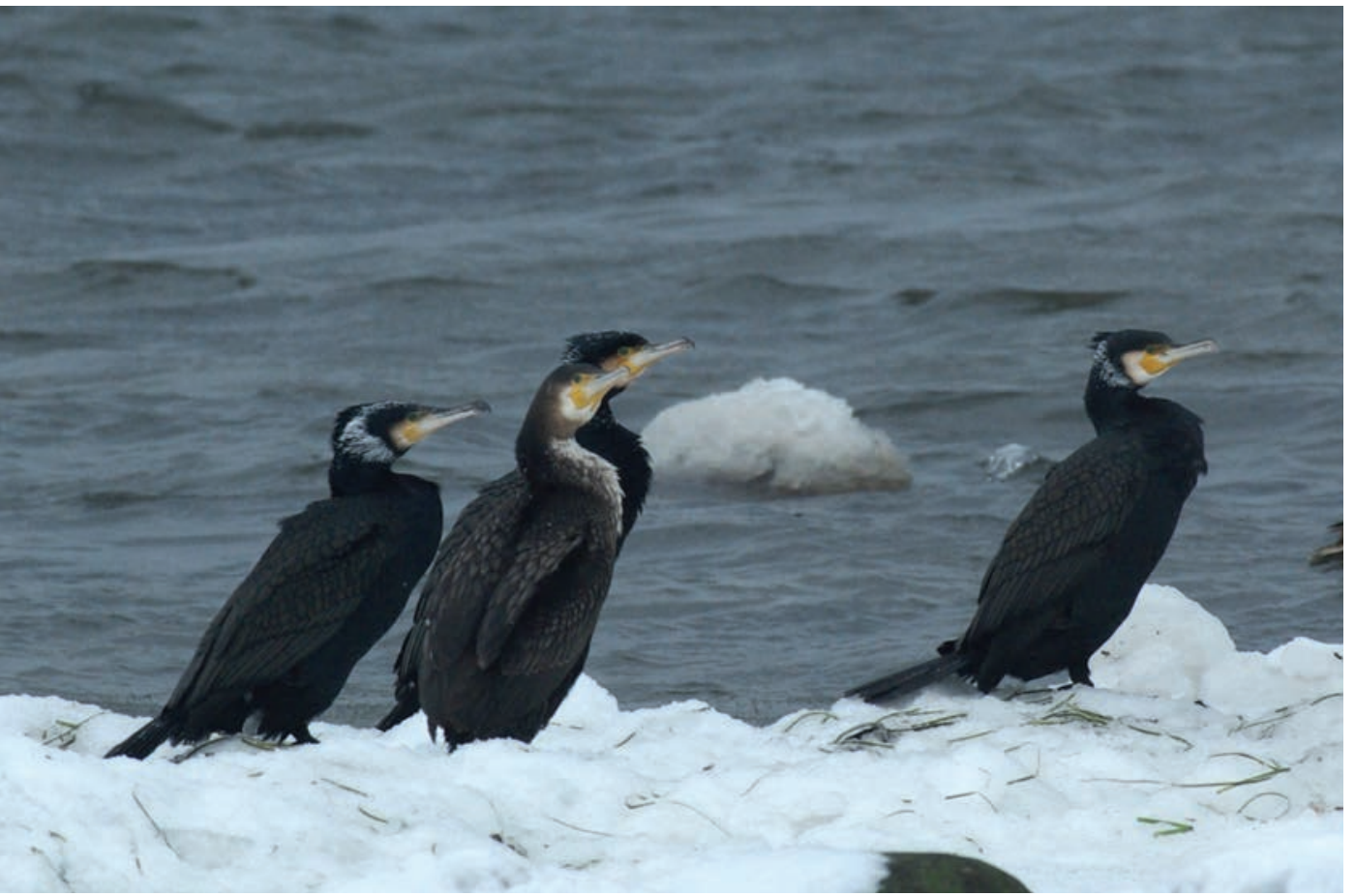

\section{Cormorant}


Table 4. Total numbers of wintering waterbirds in regions A-L (from northern Kattegat through northern Kalmarsund, Öland and Gotland; Figure 1) at surveys covering the inshore areas of this entire area. Species marked with a dash for 1971 were not counted during that year. For Clangula hyemalis, Melanitta fusca and Melanitta nigra (marked with grey in the table) only a small proportion of the total populations are found close to the shore, so the figures presented do not represent total population estimates for the regions but are the numbers actually counted in surveys of the inshore areas.

Antalet övervintrande sjöfåglar räknade i regionerna $A-L$ (från $N$ Kattegatt till och med Kalmarsund, Öland och Gotland; Figur 1) vid räkningar som täckte de inre farvattnen i hela detta område. Arter markerade med streck 1971 räknades inte det året. För alfågel, svärta och sjöorre (markerade med grått i tabellen) återfinns endast en mindre andel av det totala beståndet nära stranden, varför de angivna siffrorna inte representerar några beståndsskattningar utan endast anges vad som räknats vid inventeringarna av de inre farvattnen.

\begin{tabular}{|c|c|c|c|c|c|c|c|c|}
\hline Species Art & 1971 & 1972 & 1973 & 1987 & 1988 & 1989 & 2004 & 2015 \\
\hline Anas platyrhynchos & 22310 & 33630 & 33290 & 18852 & 32997 & 44137 & 60476 & 72220 \\
\hline Anas crecca & 7 & 2 & 68 & 11 & 38 & 36 & 297 & 496 \\
\hline Anas penelope & 3 & 13 & 74 & 0 & 247 & 450 & 5560 & 8765 \\
\hline Anas strepera & 0 & 0 & 0 & 0 & 0 & 2 & 6 & 114 \\
\hline Anas acuta & 4 & 3 & 3 & 2 & 3 & 9 & 14 & 25 \\
\hline Aythya marila & 1100 & 121 & 364 & 216 & 3398 & 2481 & 2854 & 26850 \\
\hline Aythya fuligula & 35780 & 40950 & 66510 & 51085 & 48422 & 61715 & 145714 & 97706 \\
\hline Aythya ferina & 52 & 202 & 351 & 186 & 837 & 1188 & 2500 & 1208 \\
\hline Bucephala clangula & 14970 & 17360 & 24150 & 23552 & 21427 & 19468 & 30644 & 35282 \\
\hline Clangula hyemalis & 11312 & 29509 & 35192 & 10753 & 8144 & 7974 & 30934 & 12328 \\
\hline Polysticta stelleri & 5 & 6 & 4 & 46 & 6 & 57 & 2 & 0 \\
\hline Somateria mollissima & 1307 & 2347 & 2663 & 1388 & 2122 & 1994 & 10725 & 21980 \\
\hline Melanitta fusca & 662 & 2157 & 2570 & 31 & 843 & 700 & 1155 & 8162 \\
\hline Melanitta nigra & 626 & 431 & 221 & 14 & 193 & 537 & 4316 & 5462 \\
\hline Mergus serrator & 1865 & 2272 & 3664 & 3833 & 3599 & 2791 & 3913 & 4415 \\
\hline Mergus merganser & 4070 & 2826 & 4490 & 8218 & 2453 & 3481 & 8539 & 6539 \\
\hline Mergellus albellus & 348 & 177 & 377 & 384 & 214 & 347 & 3295 & 5733 \\
\hline Tadorna tadorna & 2 & 1 & 19 & 0 & 11 & 173 & 10 & 99 \\
\hline Cygnus olor & 4407 & 4610 & 5770 & 7817 & 7165 & 8424 & 20800 & 18990 \\
\hline Cygnus cygnus & 1247 & 902 & 859 & 975 & 414 & 467 & 1084 & 1067 \\
\hline Cygnus bewickii & 0 & 0 & 0 & 0 & 0 & 0 & 0 & 8 \\
\hline Fulica atra & 3700 & 6264 & 9330 & 1710 & 1890 & 1560 & 14472 & 11193 \\
\hline Phalacrocorax carbo & 518 & 812 & 563 & 1356 & 2343 & 1729 & 5648 & 10212 \\
\hline Phalacrocorax aristotelis & - & 0 & 0 & 0 & 0 & 0 & 0 & 2 \\
\hline Aredea cinerea & - & 15 & 34 & 21 & 75 & 72 & 392 & 556 \\
\hline Gavia arctica & - & 1 & 1 & 2 & 52 & 10 & 112 & 36 \\
\hline Gavia stellata & - & 2 & 2 & 1 & 212 & 91 & 14 & 123 \\
\hline Podiceps cristatus & - & 9 & 6 & 57 & 83 & 53 & 4285 & 2723 \\
\hline Podiceps griseigena & - & 0 & 0 & 4 & 11 & 9 & 33 & 20 \\
\hline Podiceps auritus & - & 2 & 3 & 0 & 2 & 1 & 70 & 86 \\
\hline Tachybaptus ruficollis & - & 0 & 0 & 1 & 1 & 4 & 76 & 34 \\
\hline Total Summa & 104295 & 144624 & 190578 & 130515 & 137202 & 159960 & 357940 & 352431 \\
\hline
\end{tabular}




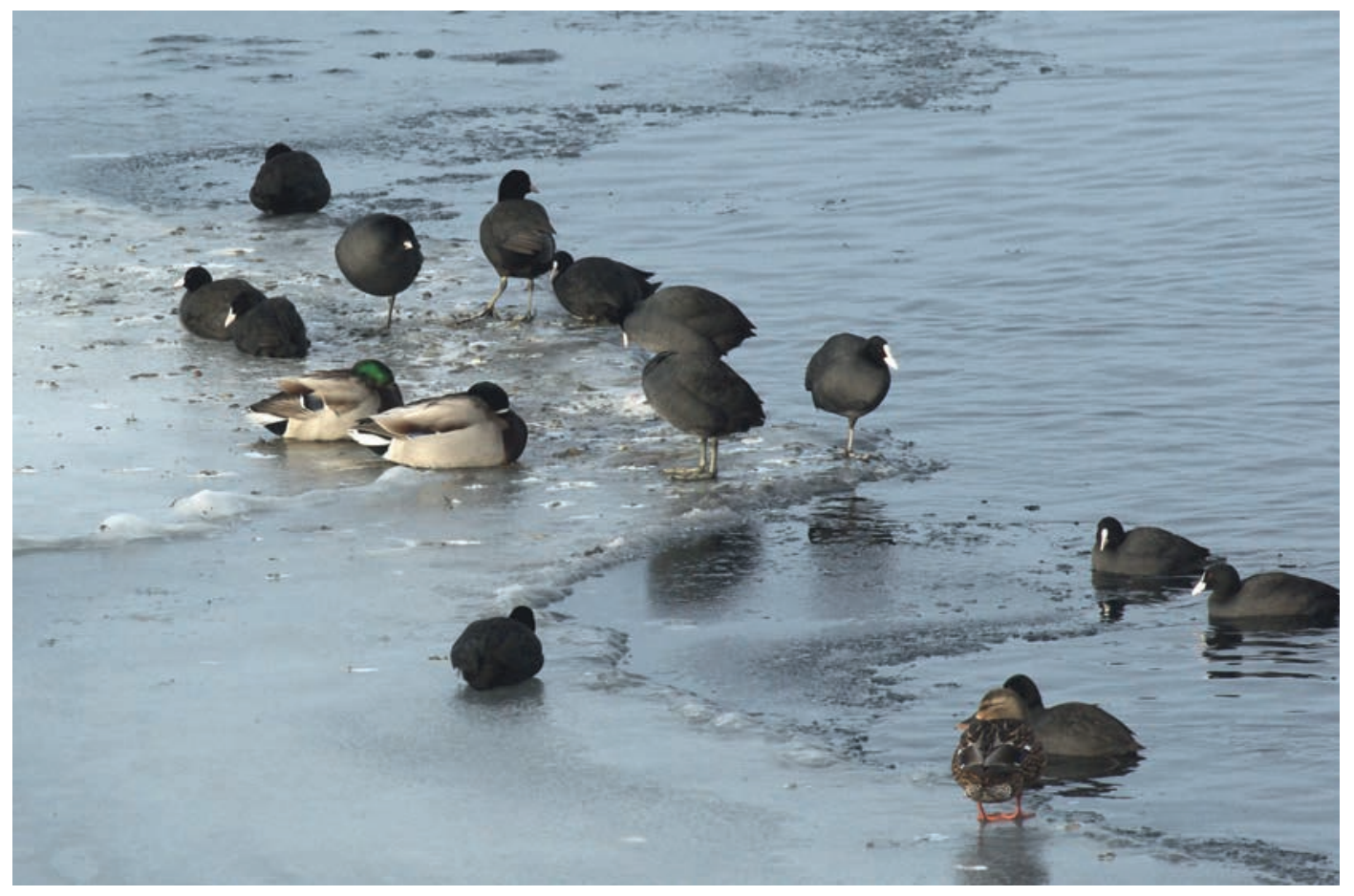

Coot and Mallard

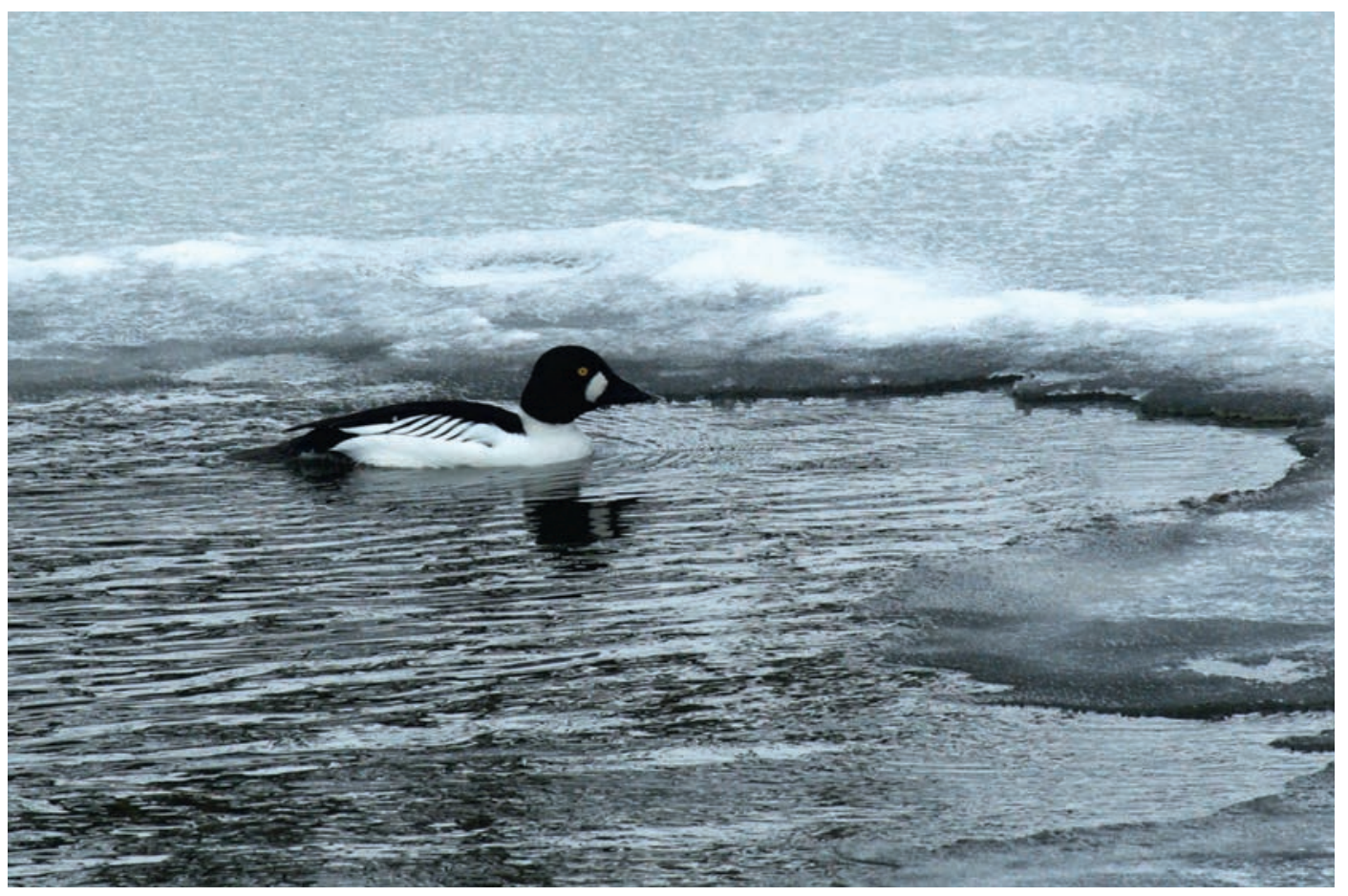

Goldeneye 
Table 5. Total numbers of wintering waterbirds counted in the regions $\mathrm{H}, \mathrm{M}, \mathrm{N}$ and $\mathrm{O}$ on the east coast, from northern Kalmar county through Stockholm archipelago (Figure 1) at surveys covering the inshore areas of the entire area. Species marked with dash for 1971 were not counted during that year. The outer parts used by Clangula hyemalis were not covered completely and no counts are shown for this species. ${ }^{*}=$ incomplete coverage 2015 (region $\mathrm{N}$ was not covered) and total estimates based on line transects.

Antalet räknade övervintrande sjöfåglar i ostkustskärgårdarna, regionerna $H, M, N$ och $O$, från norra Kalmar län till Väddö i Stockholms skärgård; Figur 1) vid inventeringar som täckte hela området. Arter markerade streck 1971 inventerades ej detta år. De yttre alfågelområdena inventerades inte fullständigt, varför alfågeldata inte redovisas här. * = ofullständig täckning 2015 (region $N$ ej inventerad) summorna är beräknade frän linjetaxeringar.

\begin{tabular}{|c|c|c|c|c|c|}
\hline Species $A r t$ & 1971 & 1972 & 1973 & 2004 & $2015^{*}$ \\
\hline Anas platyrhynchos & 4960 & 7260 & 6620 & 9090 & 11400 \\
\hline Anas crecca & 0 & 0 & 0 & 3 & 0 \\
\hline Anas penelope & 0 & 0 & 0 & 1 & 6 \\
\hline Anas strepera & 0 & 0 & 0 & 1 & 0 \\
\hline Anas acuta & 0 & 0 & 0 & 0 & 0 \\
\hline Aythya marila & 0 & 3 & 0 & 289 & 0 \\
\hline Aythya fuligula & 15395 & 16662 & 17285 & 78622 & 70100 \\
\hline Aythya ferina & 0 & 52 & 41 & 157 & 0 \\
\hline Bucephala clangula & 1010 & 2140 & 2380 & 26325 & 41950 \\
\hline Clangula hyemalis & - & - & - & - & - \\
\hline Polysticta stelleri & 3 & 0 & 1 & 1 & 0 \\
\hline Somateria mollissima & 229 & 481 & 336 & 160 & 45 \\
\hline Melanitta fusca & 4 & 2 & 71 & 7 & 0 \\
\hline Melanitta nigra & 2 & 12 & 41 & 65 & 0 \\
\hline Mergus serrator & 110 & 100 & 50 & 57 & 15 \\
\hline Mergus merganser & 3590 & 4370 & 4570 & 8425 & 25671 \\
\hline Mergellus albellus & 0 & 0 & 16 & 345 & 2272 \\
\hline Tadorna tadorna & 0 & 0 & 0 & 0 & 0 \\
\hline Cygnus olor & 1477 & 1224 & 1732 & 6584 & 27830 \\
\hline Cygnus cygnus & 20 & 19 & 19 & 51 & 29 \\
\hline Fulica atra & 120 & 1020 & 4950 & 652 & 0 \\
\hline Phalacrocorax carbo & 205 & 736 & 476 & 1817 & 2280 \\
\hline Aredea cinerea & - & 1 & 1 & 4 & 0 \\
\hline Gavia arctica & - & 1 & 0 & 1 & 0 \\
\hline Gavia stellata & - & 2 & 1 & 2 & 0 \\
\hline Podiceps cristatus & - & 0 & 4 & 12 & 0 \\
\hline Podiceps griseigena & - & 0 & 2 & 0 & 0 \\
\hline Podiceps auritus & - & 0 & 0 & 0 & 0 \\
\hline Tachybaptus ruficollis & - & 1 & 0 & 2 & 0 \\
\hline Total Summa & 27125 & 36086 & 38596 & 138696 & 197348 \\
\hline
\end{tabular}


ure 1) during 2015), the totals for the other species in the inshore areas were four to six times higher in the two later surveys compared with the seventies. Very marked changes were found for most common species.

\section{Species accounts}

In this section the distribution and numbers of the more common wintering species in 2015 are discussed separately. For each species a map showing the national distribution according to the counts in 2015 is presented. Similar maps for the two previous country-wide surveys are found in Nilsson (2008), where details for the previous surveys can also be found. For some of the more common species their detailed distribution in three archipelago areas (the central part of the archipelago of Bohuslän (region V), Småland - Östergötland (regions $\mathrm{H}$ and $\mathrm{M}$ ) and the Stockholm archipelago (region $\mathrm{O})$ ) is shown in maps. Changes in the distribution of the more common species between the three country-wide surveys over four larger regions (see division in Figure 1) are also presented in a series of graphs. Long-term and short-term trends for the different species will be discussed later (p 31).

\section{Mallard Anas platyrhynchos}

The most wide-spread species in winter is the Mallard which was found in good numbers over most of south Sweden, i.e. in the parts of the country where ice-free water was available. Along the coasts the species was found to be common in all areas except the east coast archipelagos north of

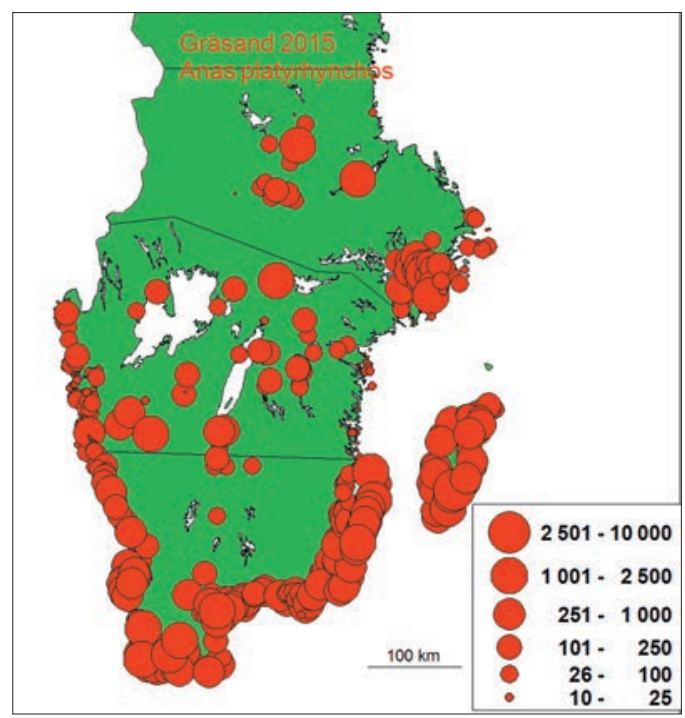

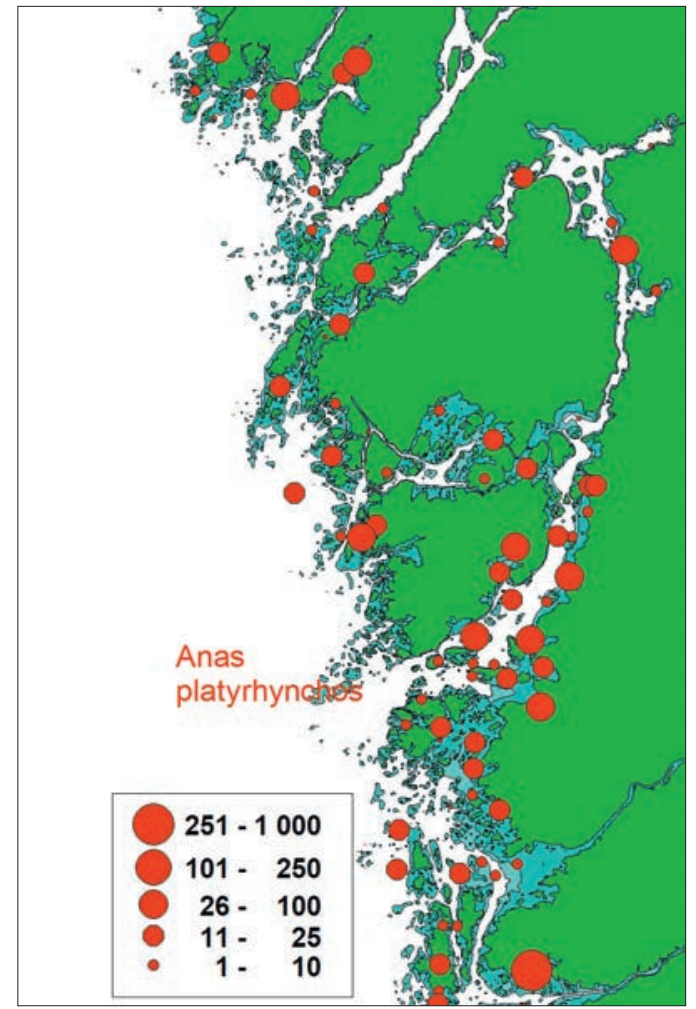

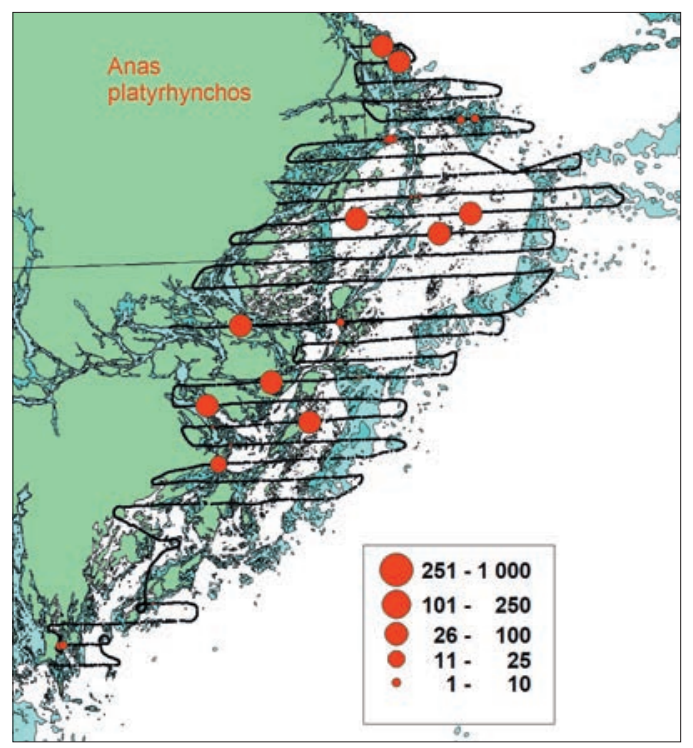

Figure 7. National and regional midwinter distribution of Mallard Anas platyrhynchos in 2015.

Gräsandens midvinterutbredning på nationell och regional nivå 2015. 


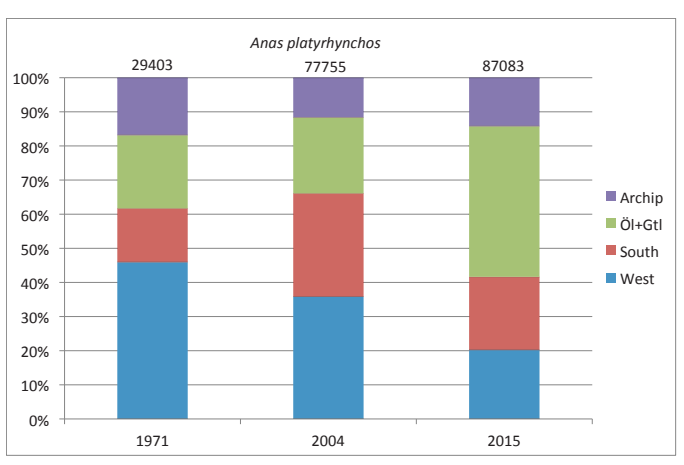

Figure 8. The percentage distribution of Mallard Anas platyrhynchos in four larger regions along the coasts of south Sweden during the country-wide surveys in 1971, 2004 and 2015. Total numbers counted or estimated shown above the bars.

Utbredning i procent för gräsand inom fyra större regioner längs kusterna av södra Sverige vid de landsomfattande inventeringarna 1971, 2004 och 2015. Antalet räknade eller beräknade individ av de olika arterna visas över staplarna.

Kalmarsund. The species occurs in most inland areas with open water (Figure 7). The detailed map over the west coast archipelagos shows that it is mostly concentrated to the inner waters even if some smaller groups were also found further out on the more exposed skerries. The relatively few flocks that were seen in the Stockholm archipelago occurred both in the inner and middle parts of the archipelago.

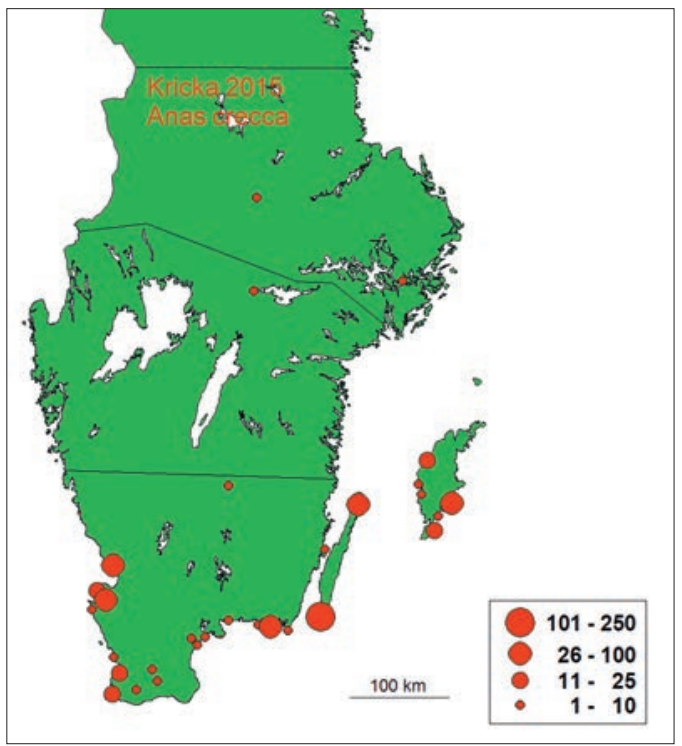

In the Mallard about $45 \%$ were found on the west coast including Öresund during the 1971 survey, this proportion decreased to about $20 \%$ in 2015 (Figure 8). During this survey the islands Öland and Gotland hosted almost $45 \%$ of all Mallards counted. The proportion of Mallards found in the archipelagos showed only small changes between the three surveys even if the total number of individuals was much larger in 2004 and 2015 than in 1971.

In all, 87000 Mallards were estimated to overwinter along the coasts in 2015, implying that the Mallard was the second commonest species in inshore coastal waters together with the Goldeneye. For the inland areas we do not have any estimate of the total wintering Mallard population for 2015 as it was a mild winter with much open water and the Mallard is wide-spread also in inland areas. During the survey in 2004 the total population of Mallards in Sweden was estimated to be about 150000 compared to 68000 in 1971. In 2004, the coastal total for the Mallard was 78000 (Table 2), i.e. almost half of the national estimate. With this in mind it is most probable that the total population for Sweden in the winter of 2015 was more than 200000.

\section{Teal Anas crecca \& Wigeon Anas penelope}

These two dabbling ducks have a restricted winter distribution in Sweden. When the counts started they were only seen in small numbers in the country during the winter but both species have estab-

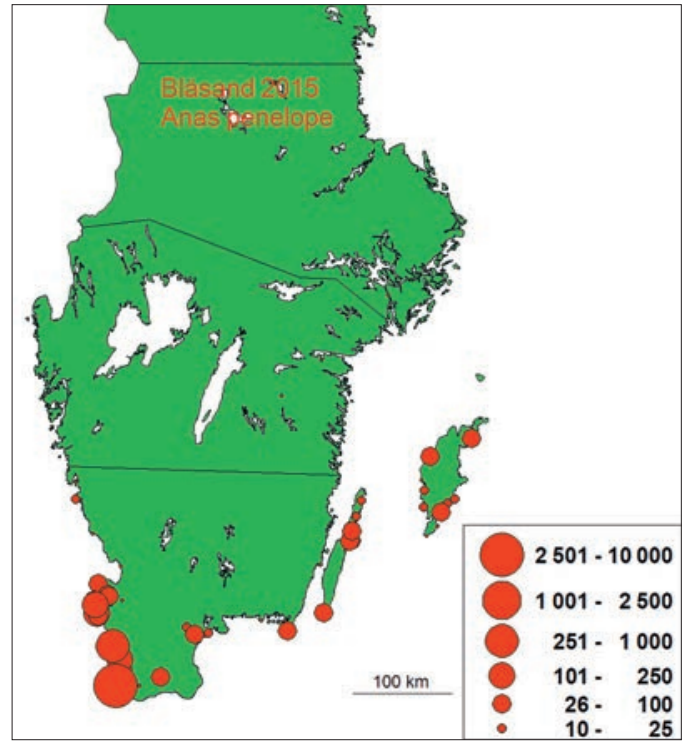

Figure 9. Midwinter distribution of Teal Anas crecca and Wigeon Anas penelope in Sweden 2015.

Midvinter utbredning för Kricka och Bläsand i Sverige 2015 

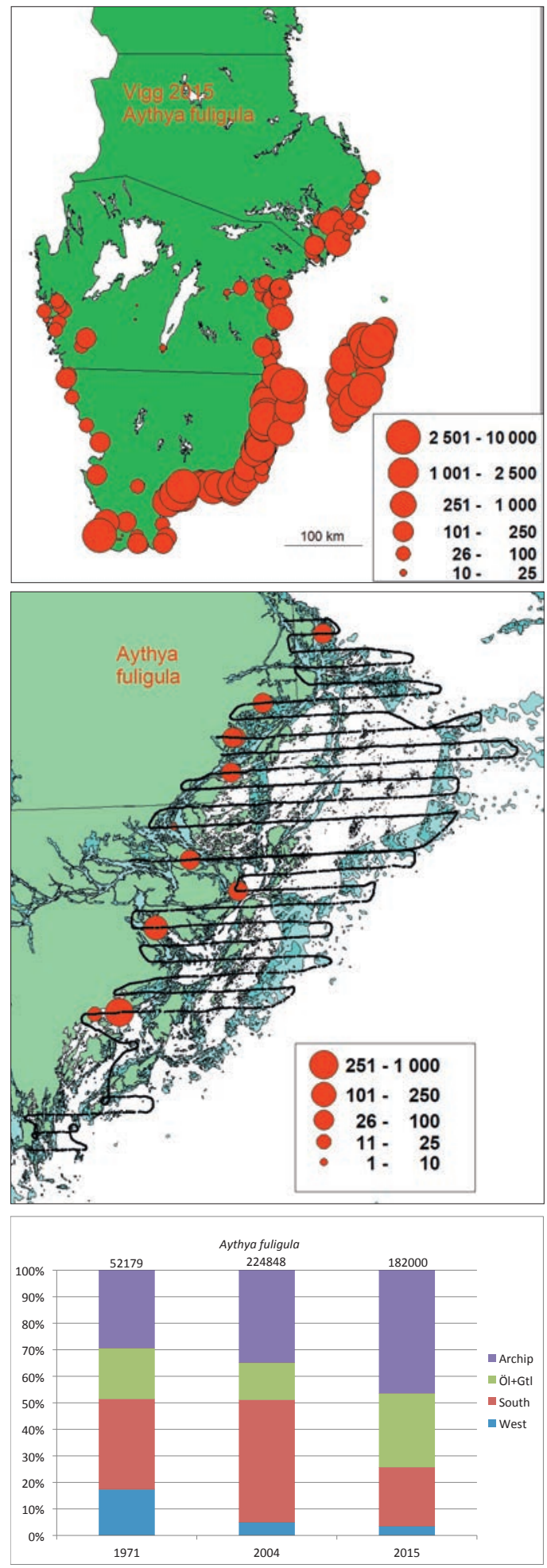

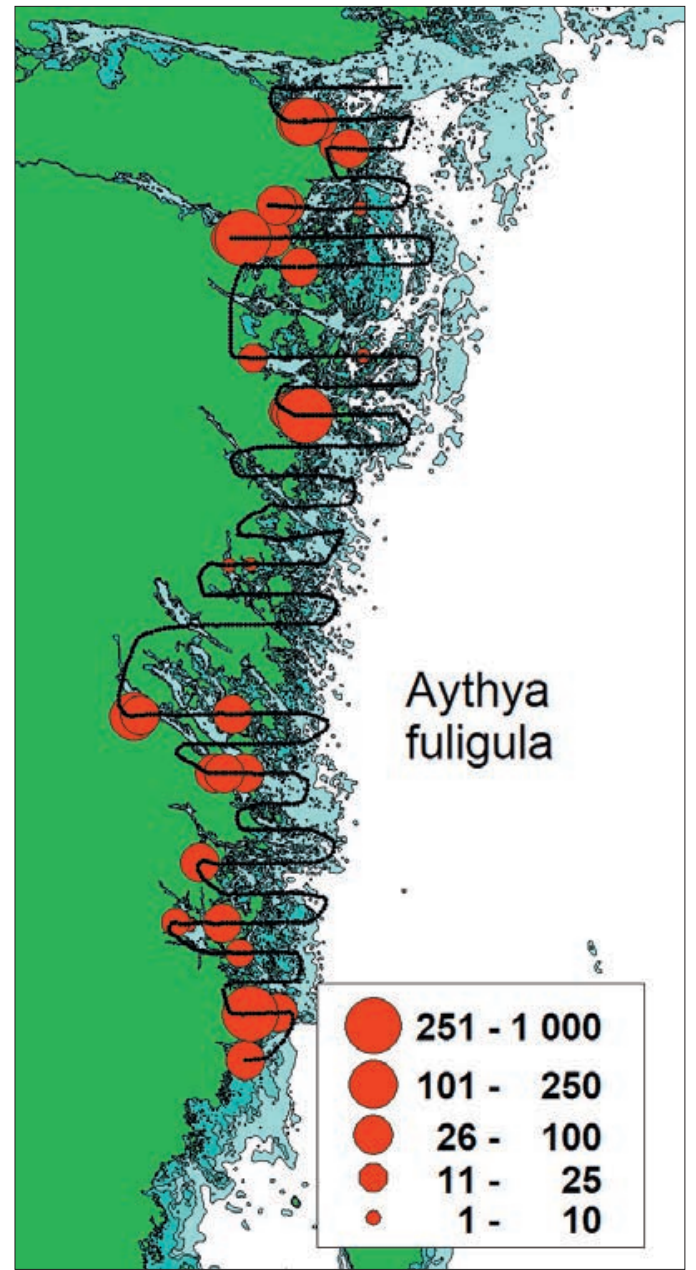

Figure 10. National and regional midwinter distribution of Tufted Duck Aythya fuligula.

Viggens midvinterutbredning på nationell och regional nivå 2015.

Figure 11. The percentage distribution of Tufted Duck Aythya fuligula in four larger regions along the coasts of south Sweden during the country-wide surveys in 1971, 2004 and 2015. Total numbers counted or estimated shown above the bars.

Utbredning i procent för vigg inom fyra större regioner längs kusterna av södra Sverige vid de landsomfattande inventeringarna 1971, 2004 och 2015. Antalet räknade eller beräknade individ av de olika arterna visas över staplarna. 
lished a wintering habit in south Sweden in more recent years. They are mostly concentrated to Scania with some occurrences on Öland and Gotland (Figure 9).

\section{Tufted Duck Aythya fuligula}

Among the diving ducks in inshore waters, the Tufted Duck was the commonest species followed by the Goldeneye and Mallard. In 2015 the total number of Tufted Ducks in the Swedish coastal waters was estimated to be 182000 compared to 225000 in 2004 and only 52200 in 1971 (Table 2). The Tufted Duck was distributed along the entire Baltic coast surveyed, with some larger concentrations also in the Öresund (Figure 10), whereas only smaller numbers were found on relatively few sites on the west coast north of Öresund. In the east coast archipelagos, the Tufted Ducks were markedly concentrated to the inner parts, where often large flocks were found. These sites are mainly used as daytime roosts from which the Tufted Ducks disperse over the feeding areas further out at sea (Nilsson 1972). Only low numbers were found on a small number of inland sites.

Between the surveys in 1971 and especially 2015 there was a marked shift in the distribution from about $50 \%$ in the Öresund and the South region to about $25 \%$ here in 2015, the majority of the Tufted Ducks in Swedish coastal waters being found in the archipelagos and along the big islands in the Baltic, especially Gotland (Figure 11).

\section{Scaup Aythya marila}

The Scaup was counted in unusually high numbers in 2015, 26850 individuals were observed. Most of them (88\%) were concentrated to the east coast of the island of Gotland (Figure 12). Smaller numbers were found in the flocks of the numerous Tufted Duck in some other regions, but on Gotland several pure flocks with Scaup were found.

In all three surveys the majority of Scaups has been observed in the waters surrounding the Baltic islands and especially Gotland, but some flocks regularly occur also in the southern region and a few in Öresund (Figure 13). The total number in 2015 was much higher than in the other two surveys and the dominance for Gotland was much more marked.

\section{Pochard Aythya ferina}

Most Pochards occurred in a few areas along the coasts of south Sweden with a marked concentration in the province of Blekinge (Figure 12). Totally 1208 individuals were observed in 2015, which can be compared with the 2660 Pochards that were counted in 2004. The total was much lower in 1971, with only 92 registered individuals. The Pochard will easily be underestimated during aerial surveys as they occur in the larger flocks of Tufted Ducks. In 2015 smaller numbers were also found inland.

\section{Goldeneye Bucephala clangula}

The Goldeneye is well spread along the entire coast covered in the present survey (Figure 14), being equally common on the west and east coast. In all, 87000 Goldeneyes were estimated to be present in the areas surveyed in 2015 , but this does not fully represent the national total for the species. The Goldeneye is well spread in small numbers on several inland sites and there was only little ice in the inland of south Sweden in 2015. The same applies to the coasts north of the surveyed areas in the Baltic. During the earlier surveys these inshore areas were ice-covered but in 2015 many ice-free areas potentially used by the Goldeneye was not covered by counts. It is therefore highly probable that the wintering population of Goldeneyes in Sweden was between 90000 and 95000 or even higher. The coastal total for the inshore areas in 2004 was 72000 , whereas the total for 1971 was appreciably lower, 17600 (Table 2).

On the west coast, the Goldeneyes were mainly found in the inner parts of the archipelagos, even if some flocks were found on more exposed sites (Figure 14). In the narrow archipelago of Östergötland and Småland (regions $\mathrm{H}$ and $\mathrm{M}$ in Figure 1), they were also found in the innermost areas, whereas they occurred some distance from the mainland coast in the much wider Stockholm archipelago, but there were no Goldeneyes in the outer parts of this archipelago.

The Goldeneye is the species showing the most marked change in the distribution between the surveys (Figure 15). In 1971, only about 5\% of the total coastal number was from the archipelagos compared to about $50 \%$ in the survey in 2015 . In the same time there were marked changes in the total counts of the species. 2004 were somewhat in between when it comes to the distribution over the areas and the counts were not markedly lower than in 2015.

\section{Velvet Scoter Melanitta fusca \& Common Scoter Melanitta nigra}

In the inshore coastal areas covered by the present survey, the Velvet Scoter and the Common Scoter were only found in larger numbers in Skälderviken 

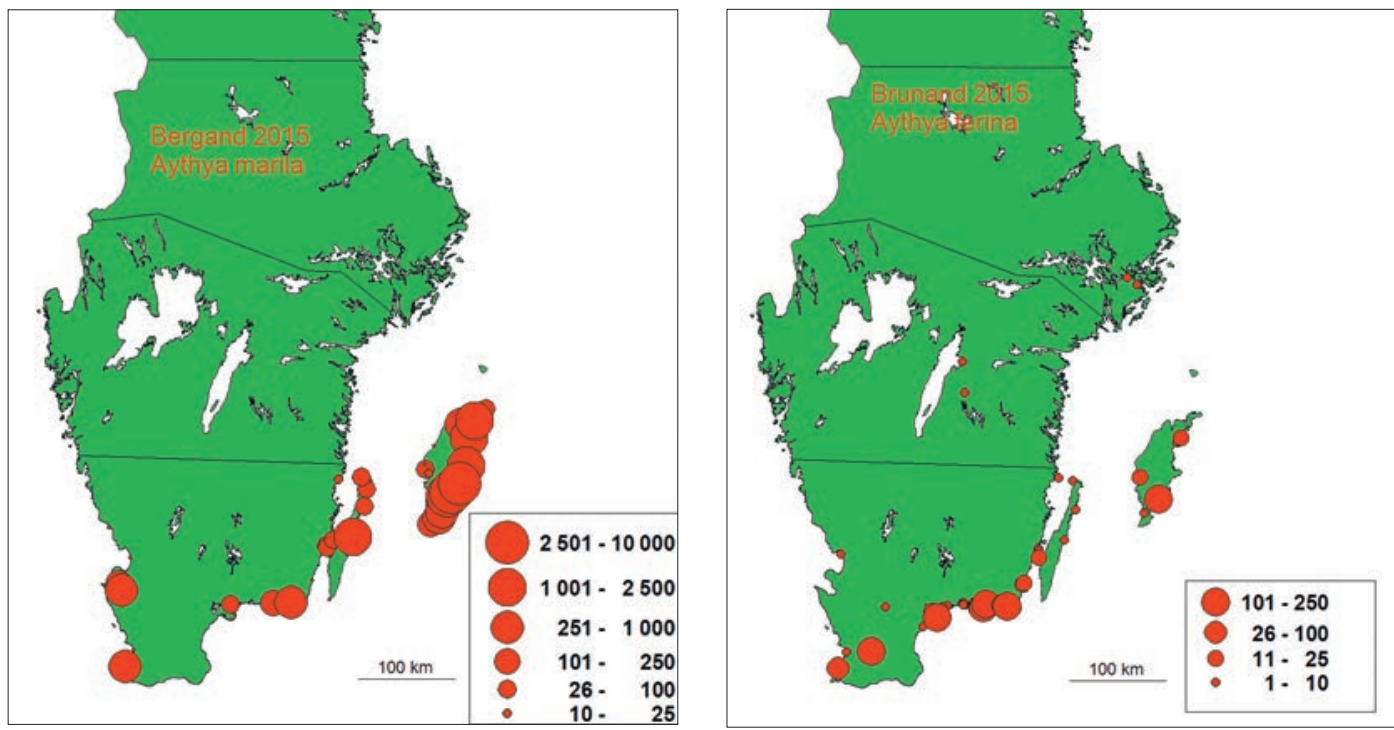

Figure 12. Midwinter distribution of Scaup Aythya marila and Pochard Aythya ferina in Sweden 2015.

Midvinter utbredning för Bergand och Brunand $i$ Sverige 2015.

and Laholmsbukten in southern Kattegat (Figure 16). In the other areas only small numbers of these two species were recorded from the shoreline. Both species do however in most areas stay far out at sea, not being seen from the shore, they are regular in relatively large flocks in offshore waters south of Falsterbo and in Hanöbukten (Nilsson 2012, Green \& Nilsson 2015).

In Skälderviken and Laholmsbukten in southern Kattegat large proportion of the scoters can be counted from the shoreline in good weather condi-

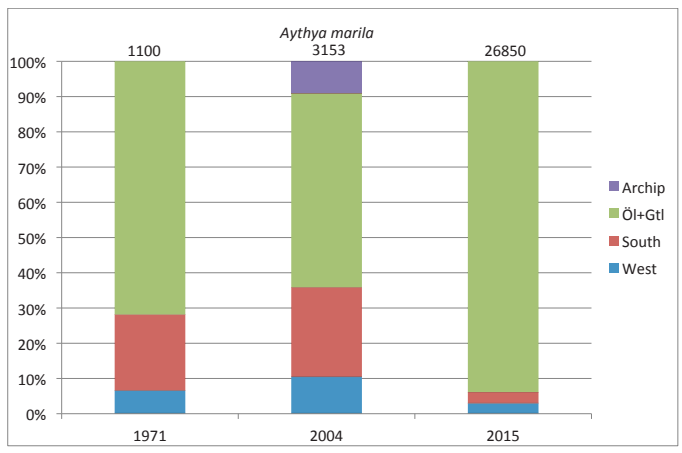

Figure 13. The percentage distribution of Scaup Aythya marila in four larger regions along the coasts of south Sweden during the country-wide surveys in 1971, 2004 and 2015. Total numbers counted or estimated are shown above the bars. Utbredning i procent för bergand inom fyra större regioner längs kusterna av södra Sverige vid de landsomfattande inventeringarna 1971, 2004 och 2015. Antalet räknade eller beräknade individer av de olika arterna visas över staplarna. tions. In 2015, the total number of Common Scoters counted from the shore in south Swedish waters (Table 4) was 8162 and the number of Velvet Scoters was 5462.

\section{Eider Somateria mollissima}

The Eider was concentrated to the west coast and was not found in any of the other archipelagos covered by the 2015 survey (Figure 17). The only area not covered by the present survey where

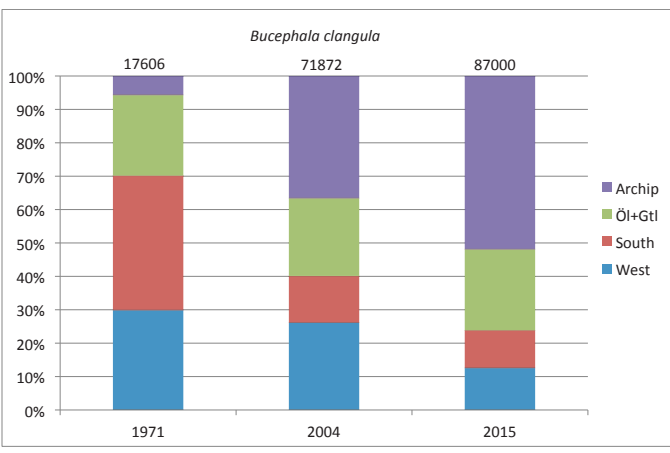

Figure 15. The percentage distribution of Goldeneye Bucephala clangula in four larger regions along the coasts of south Sweden during the country-wide surveys in 1971, 2004 and 2015. Total numbers counted or estimated shown above the bars.

Utbredning $i$ procent för knipa inom fyra större regioner längs kusterna av södra Sverige vid de landsomfattande inventeringarna 1971, 2004 och 2015. Antalet räknade /beräknade individer av de olika arterna visas över staplarna. 

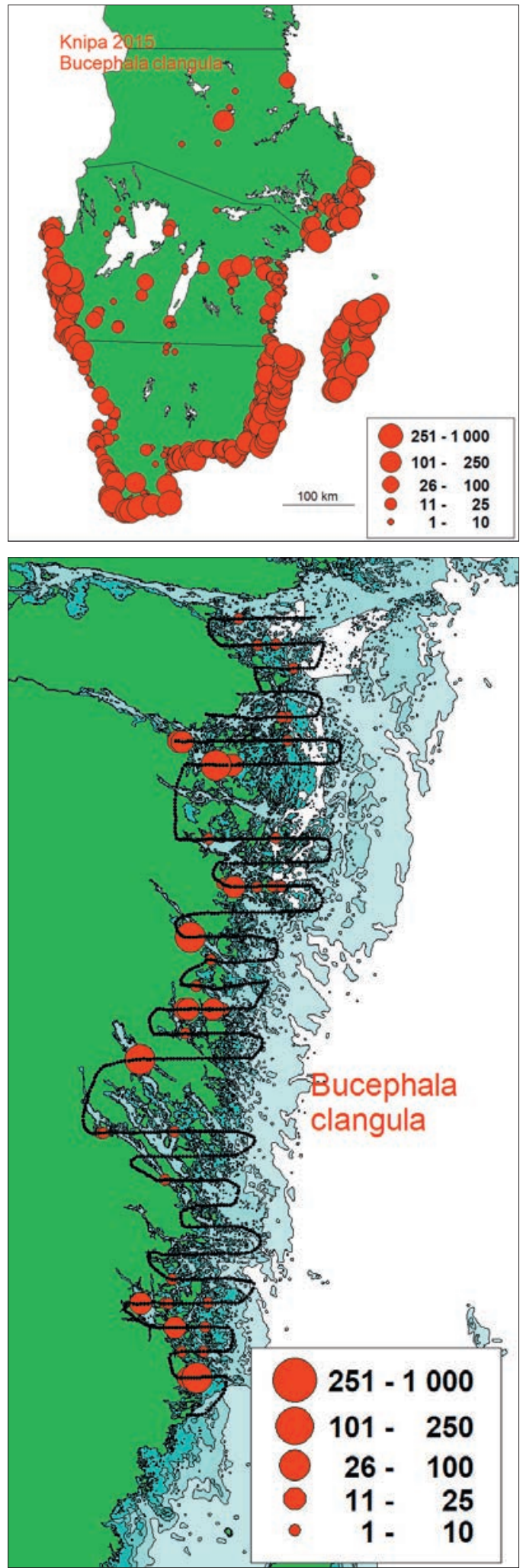

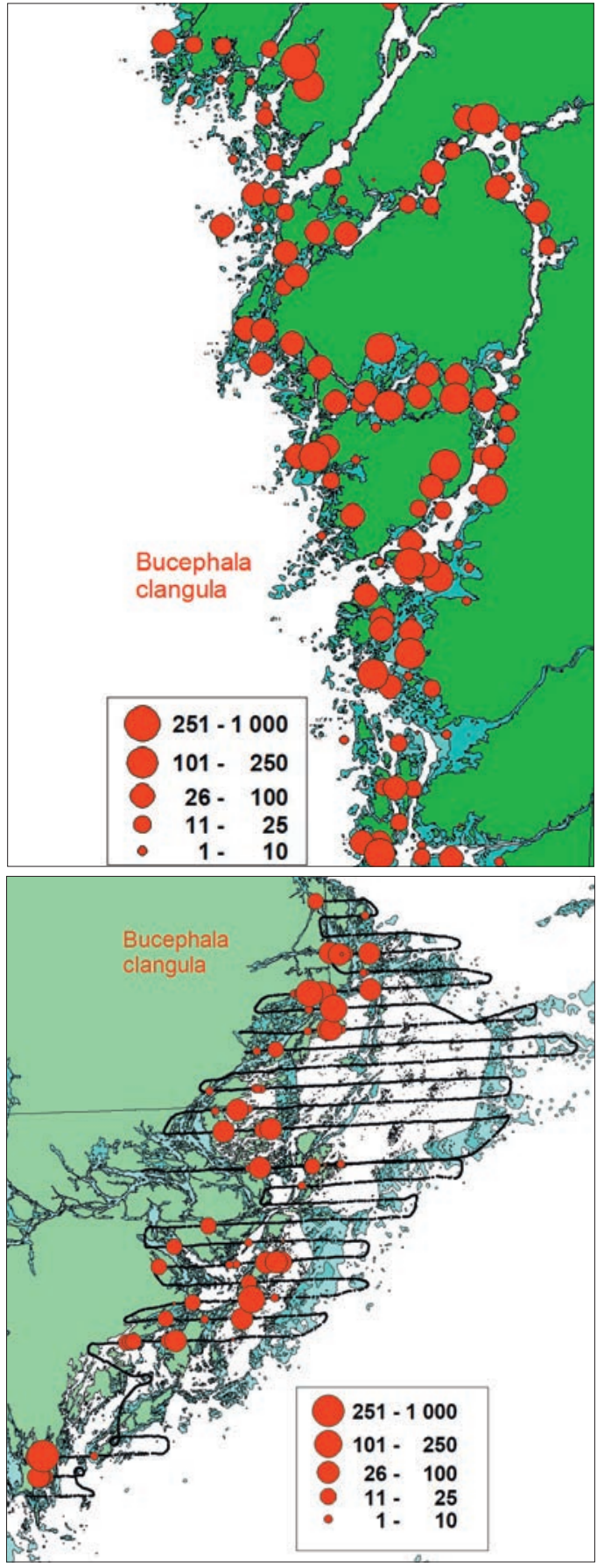

Figure 14.National and regional midwinter distribution of Goldeneye Bucephala clangula.

Knipans midvinterutbredning på nationell och regional nivå 2015 

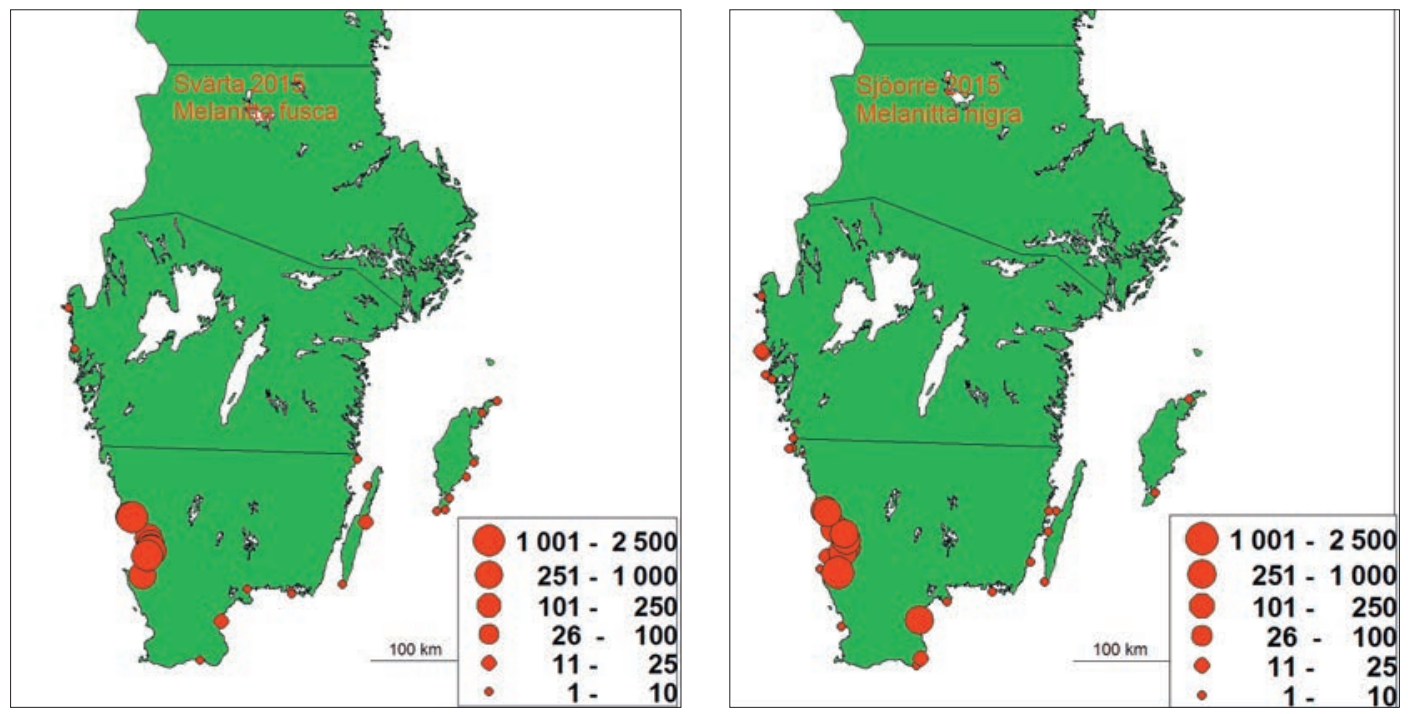

Figure 16. Midwinter distribution of Velvet Scoter Melanitta fusca and Common Scoter Melanitta nigra in Sweden 2015. Midvinter utbredning för svärta och sjöorre i Sverige 2015.
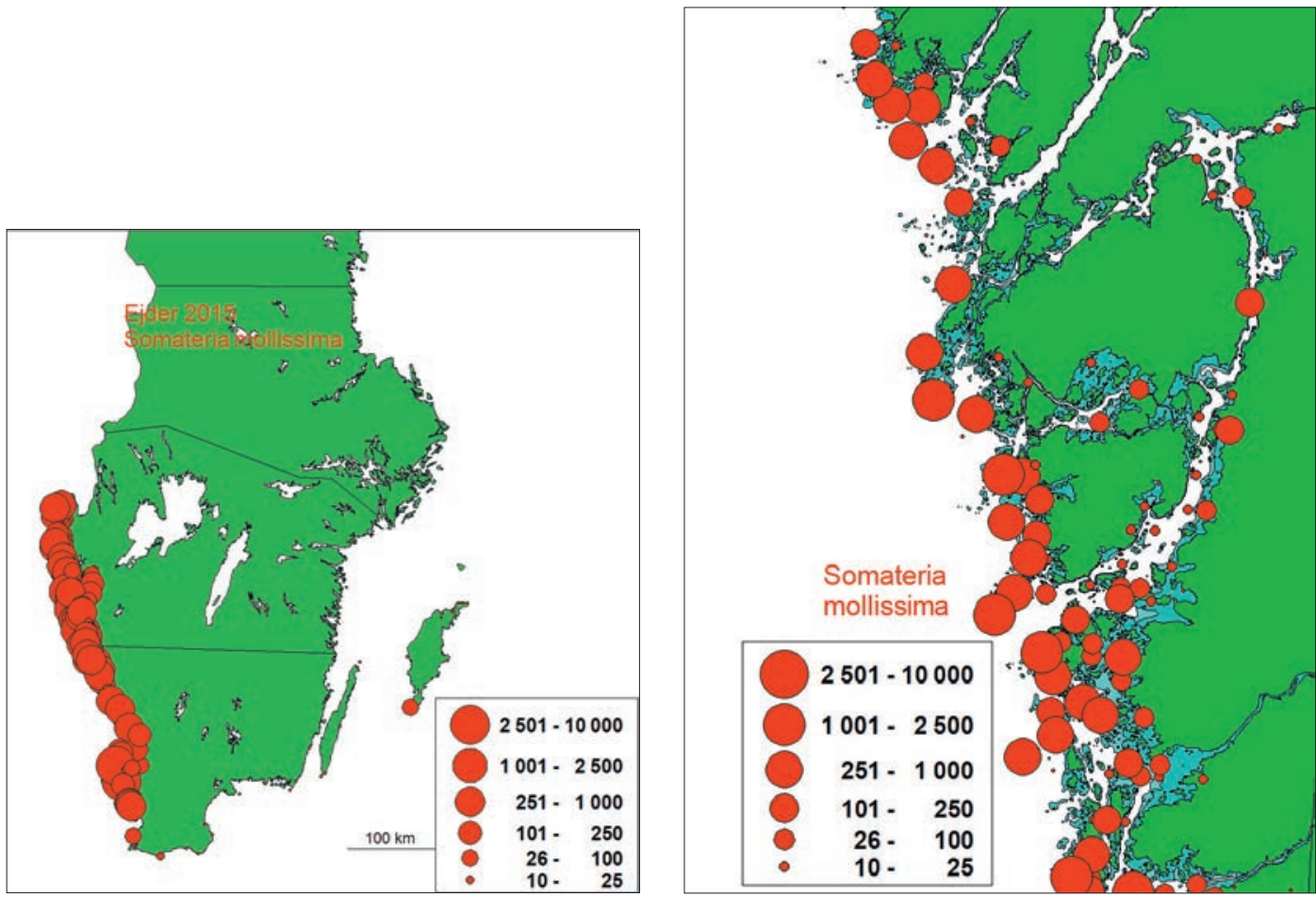

Figure 17. Midwinter distribution of Eider Somateria mollissima in Sweden 2015 with details for a part of the Swedish west coast.

Midvinterutbredning för ejder i Sverige 2015 med detaljer för en del av den svenska västkusten. 


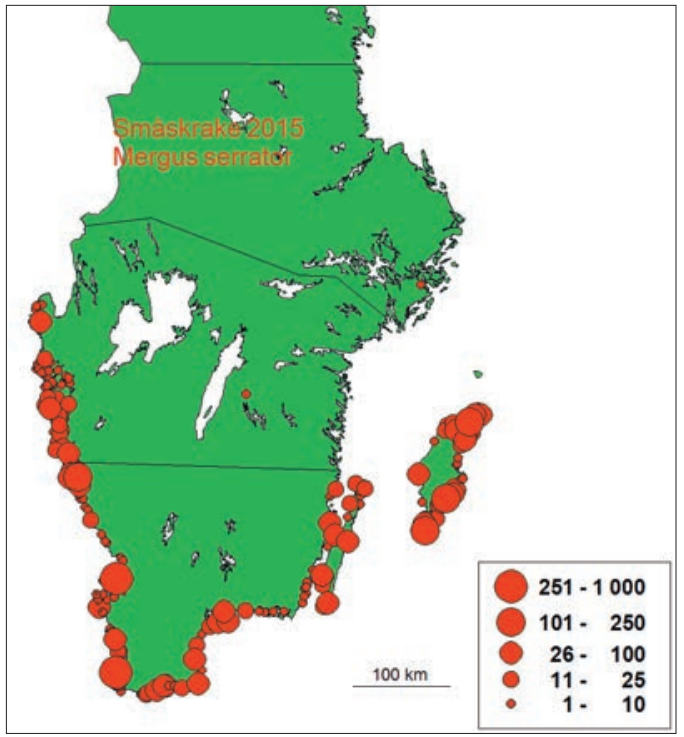

Figure 18. Midwinter distribution of Red-breasted merganser Mergus serrator in Sweden 2015 with details for a part of the Swedish west coast.

Midvinterutbredning för småskrake i Sverige 2015 med detaljer för en del av den svenska västkusten.

large flocks are known to occur is the offshore waters south of Falsterbo (Green \& Nilsson 2015). In other parts of the Baltic only small numbers were found, for example at the southern tip of Gotland. In the archipelagos of Bohuslän (Figure17) the majority of Eiders were found in the outer zone with small skerries and sea shallows and only few individuals were found in the more sheltered inner water areas.

In the areas covered in 2015, 51700 Eiders were counted, which is slightly more than in 2004, when 49000 were present in the same areas. These two estimates were markedly higher than the total for 1971, when only 4500 were observed. Based on the offshore surveys south of Falsterbo (Green \& Nilsson 2015, Nilsson 2012), there could be a further 10 000-13 000 Eiders in these waters, bringing the national total to little more than 60000 .

\section{Red-breasted merganser Mergus serrator}

The Red-breasted Merganser was distributed all around the coasts of south Sweden from the Norwegian Border to the northern part of Kalmarsund and around Öland and Gotland (Figure 18) but almost absent elsewhere. In the west coast archipelagos they occurred mostly in small groups spread over both the more sheltered and more exposed parts, but some flocks were found further to the
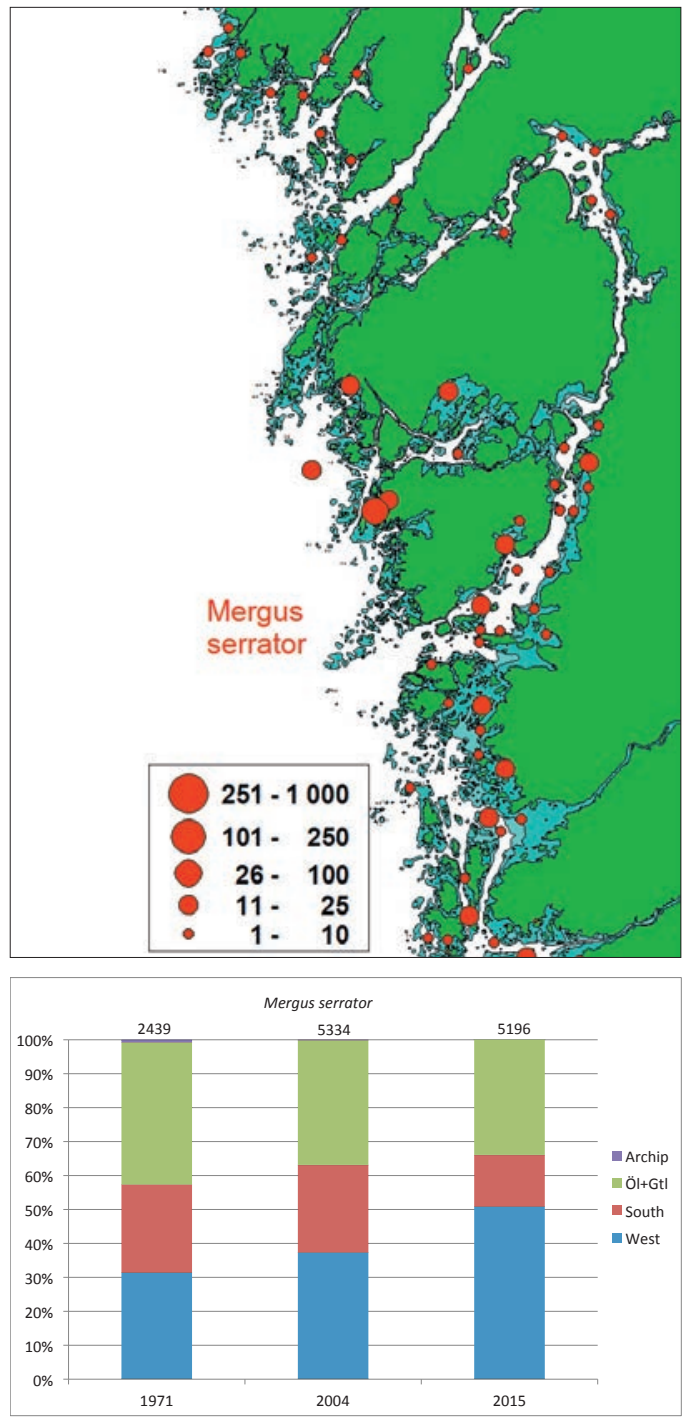

Figure 19. The percentage distribution of Red-breasted merganser Mergus serrator in four larger regions along the coasts of south Sweden during the country-wide surveys in 1971, 2004 and 2015. Total numbers counted or estimated shown above the bars.

Utbredning i procent för småskrake inom fyra större regioner längs kusterna av södra Sverige vid de landsomfattande inventeringarna 1971, 2004 och 2015. Antalet räknade eller beräknade individ av de olika arterna visas över staplarna.

sea. In 2015, the national total for inshore areas was 5200 compared to 5300 in 2004 . As for most other species the wintering total was much lower in 1971, 2400. The totals do not represent the total wintering population of the species for Sweden as much larger numbers are sometimes found offshore 

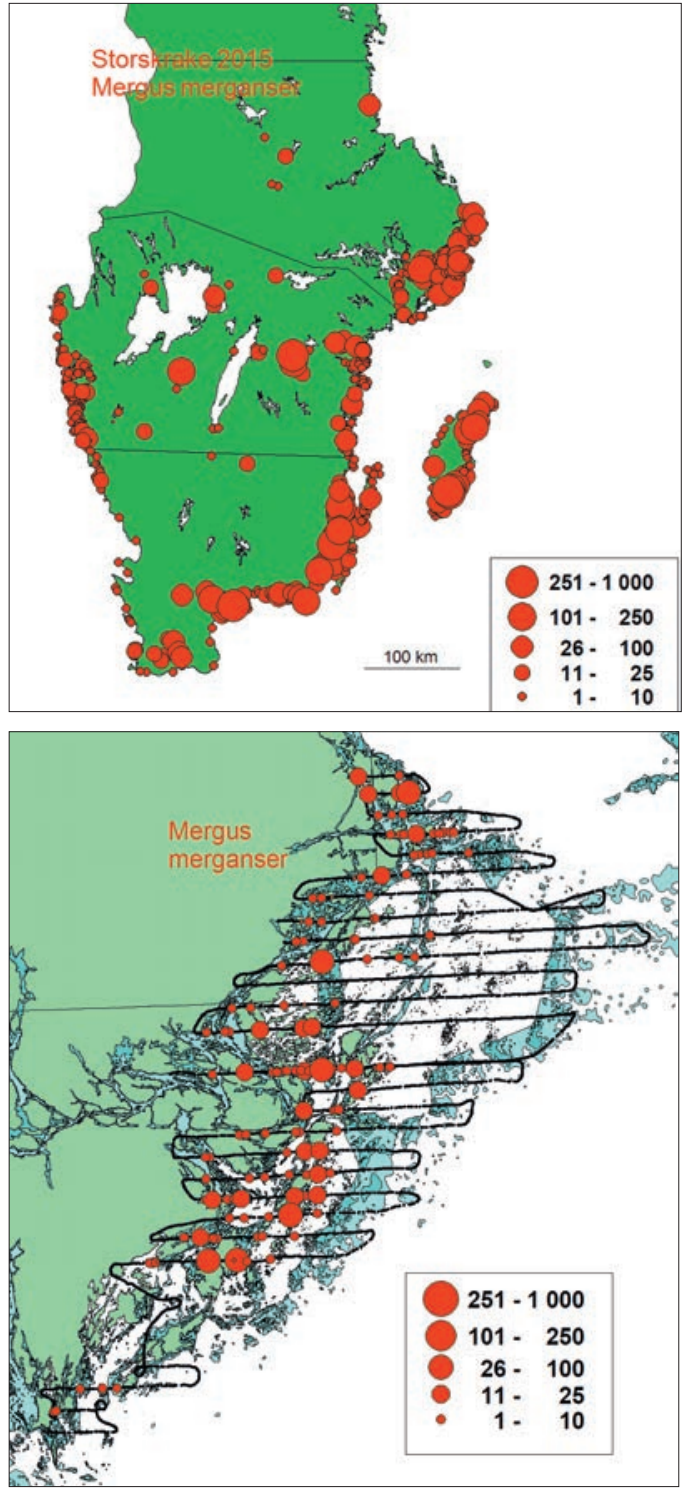

Mergus merganser

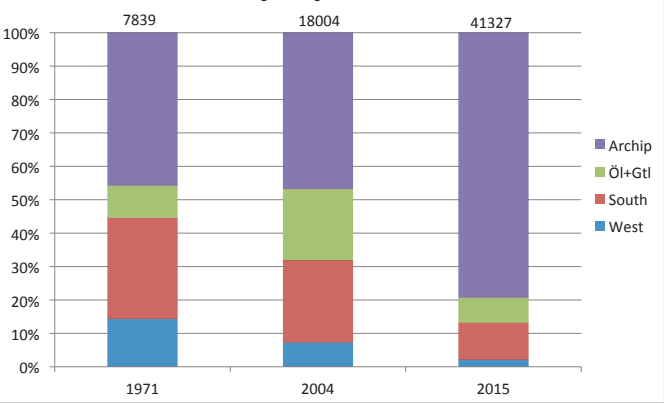

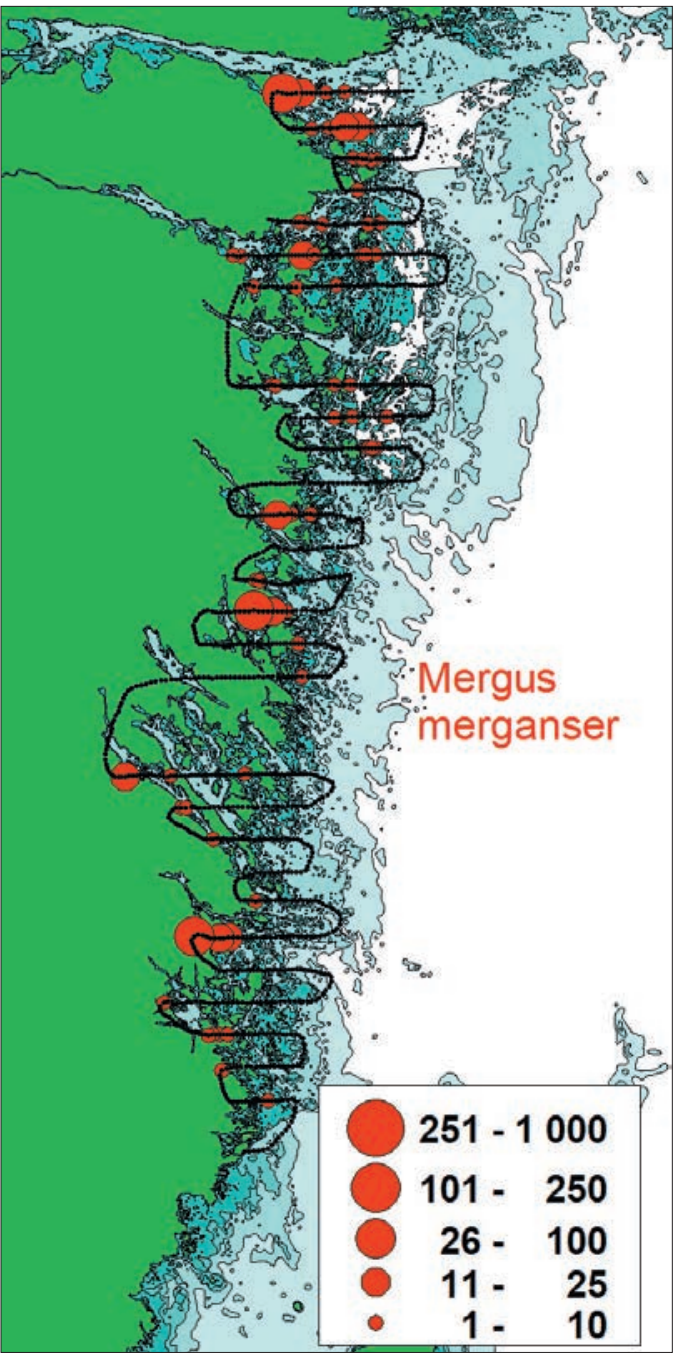

Figure. 20.National and regional midwinter distribution of Goosander Mergus merganser in Sweden 2015.

Storskrakens midvinterutbredning på nationell och regional nivå i Sverige 2015

Figure 21. The percentage distribution of Goosander Mergus merganser in four larger regions along the coasts of south Sweden during the country-wide surveys in 1971, 2004 and 2015. Total numbers counted or estimated shown above the bars.

Utbredning i procent för storskrake inom fyra större regioner längs kusterna av södra Sverige vid de landsomfattande inventeringarna 1971, 2004 och 2015. Antalet räknade eller beräknade individer av de olika arterna visas över staplarna. 
especially in SW Sweden (Nilsson 2012, Green \& Nilsson 2015).

The Red-breasted Merganser showed relatively small changes between the surveys compared to the other species, although the share for the Öresund and the west coast increased from about $30 \%$ to $50 \%$ (Figure 19). As in 2015, the species was absent from the Baltic archipelagos in the two previous surveys.

\section{Goosander Mergus merganser}

The map for the Goosander in 2015 shows a typical picture for a mild winter, with Goosanders spread over the inland part of southern Sweden and in the archipelagos both on the west coast and in the Baltic (Figure 20). Goosanders were sparsely distributed along the open coasts of Kattegat and Scania, whereas several flocks occurred on open coasts around Gotland.

In the east coast archipelagos the Goosanders were mostly found in the innermost parts of the narrow archipelagos of Kalmar and Östergötland $(\mathrm{H}+\mathrm{M}$, Figure1), whereas they were more concentrated to areas a little further from the shore in the Stockholm archipelago.

The number of Goosanders in the coastal areas covered was about 35000 in 2015, which is almost twice as many as was reported in 2004, when 18000 were counted and much higher than the 7800 estimated for 1971 (Table 2). Especially

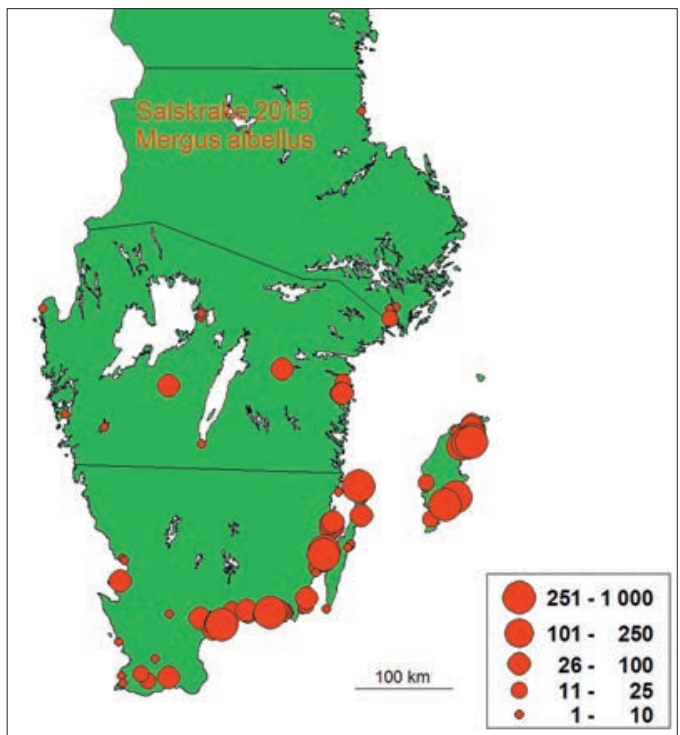

Figure 22. Midwinter distribution of Smew Mergellus albellus in Sweden 2015.

Midvinterutbredning för salskrake i Sverige 2015 during mild winters these figures do not represent national totals for the species. Like the Goldeneye, the Goosander is also found on a number of inland sites, and moreover, some Goosanders may have stayed in the ice-free areas north of the coastal areas covered by the present survey. The national total was probably a few thousand individuals higher than 35000 .

The Goosander has a totally different distribution in south Swedish waters compared to the Redbreasted merganser. The numbers occurring in the Öresund and on the west coast are normally small and the vast majority of coastal Goosanders are found in the Baltic. Even in 1971, when the total numbers counted was much lower than in 2015, a large proportion was found in the archipelagos, this share increasing to about $80 \%$ in the mild winter of 2015 (Figure 21).

\section{Smew Mergellus albellus}

In 2015, the total number of Smews wintering in Sweden was estimated to about 8000 individuals compared to 3700 in 2004 and 350 in 1971. Most Smews were noted along the south-eastern coast of Sweden with large flocks seen in the archipelago of Blekinge, in the Kalmarsund and on some sites on Gotland (Figure 22). Smaller numbers were also found inland.

At the first survey, the species was quite rare in Sweden and it was highly concentrated to the archipelago of Blekinge and to Öresund with some flocks and smaller groups on inland waters, especially in the southernmost province of Sweden,

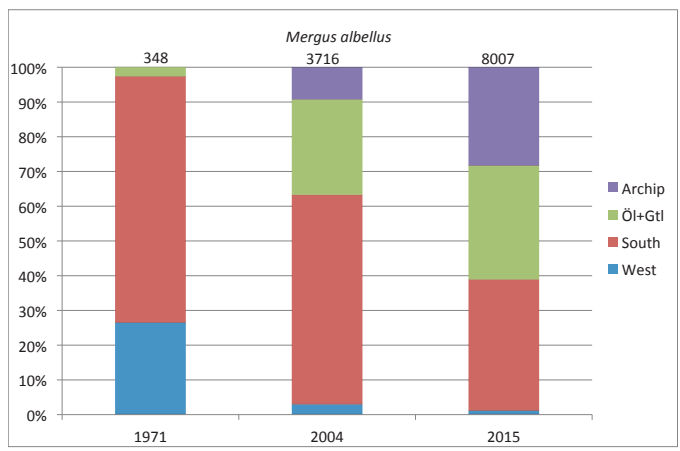

Figure 23. The percentage distribution of Smew Mergellus albellus in four larger regions along the coasts of south Sweden during the country-wide surveys in 1971, 2004 and 2015. Total numbers counted or estimated shown above the bars.

Utbredning $i$ procent för salskrake inom fyra större regioner längs kusterna av södra Sverige vid de landsomfattande inventeringarna 1971, 2004 och 2015. Antalet räknade eller beräknade individer av de olika arterna visas över staplarna. 

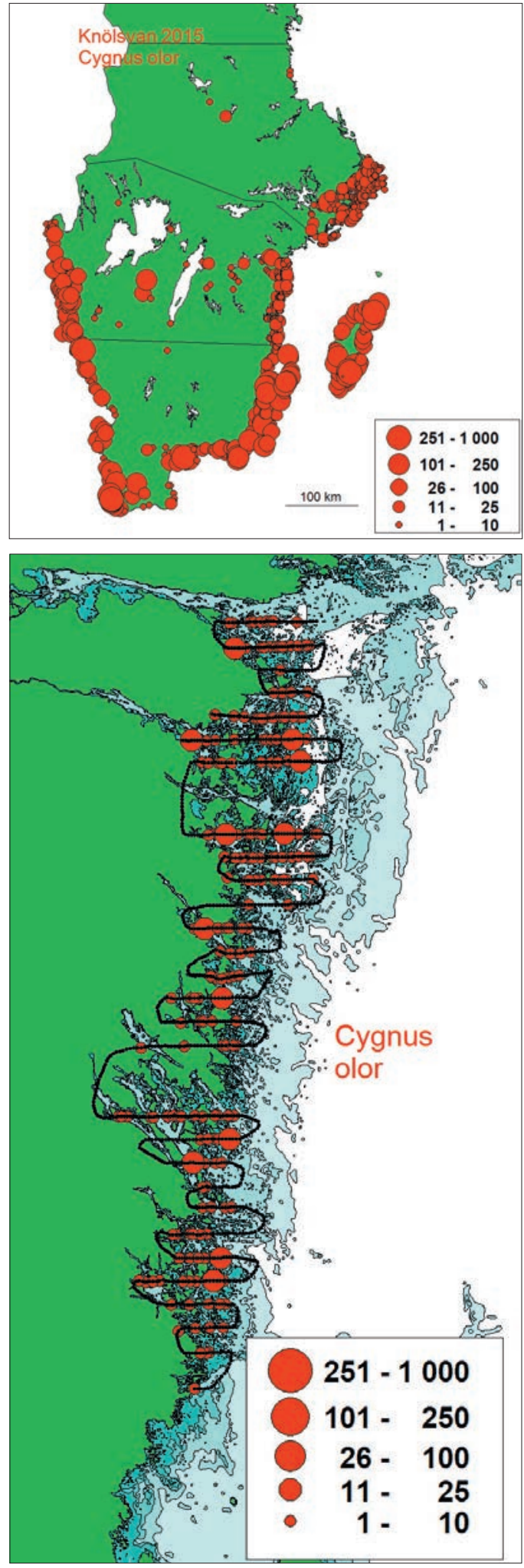
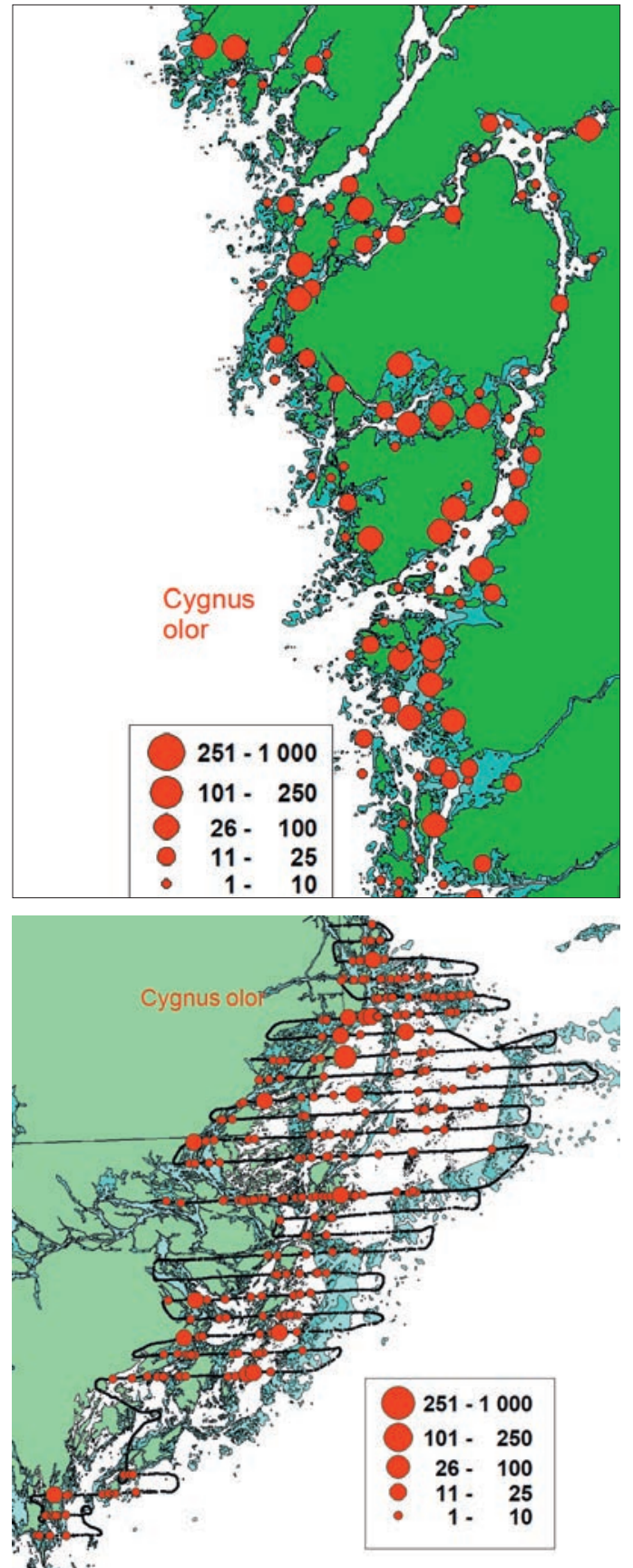

Figure 24.National and regional midwinter distribution of Mute Swan Cygnus olor in Sweden 2015.

Knölsvanens midvinterutbredning på nationell och regional nivå i Sverige 2015. 


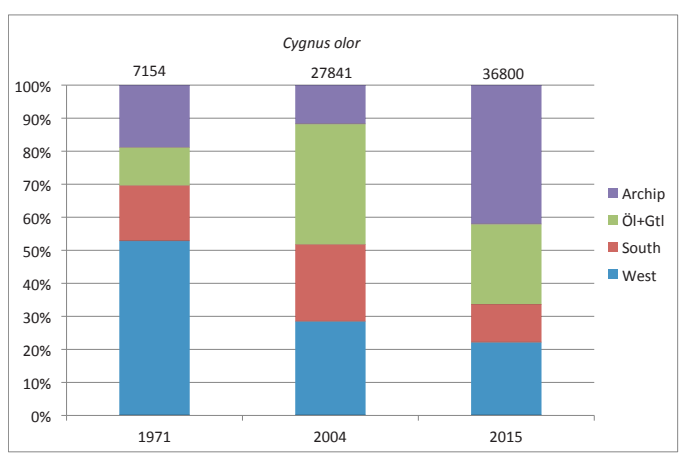

Figure 25. The percentage distribution of Mute Swan Cygnus olor in four larger regions along the coasts of south Sweden during the country-wide surveys in 1971, 2004 and 2015. Total numbers counted or estimated shown above the bars. Utbredning i procent för knölsvan inom fyra större regioner längs kusterna av södra Sverige vid de landsomfattande inventeringarna 1971, 2004 och 2015. Antalet räknade eller beräknade individer av de olika arterna visas över staplarna.

Scania. At the next survey, in 2004, the situation had changed but the majority $(60 \%)$ were still found in the south. However, some flocks had begun to appear in the Archipelago and the Large Islands (Figure 23). This trend was accentuated in 2015 . This winter the numbers were roughly equal in the three larger Baltic areas (3000 in South, 2600 in Large Islands and 2200 in Archipelago) but the proportional increase was larger towards northeast, $36 \%, 160 \%$ and $540 \%$, respectively. The change in South was moderate and in one of the regions E, Blekinge, there was no change at all. Numbers were thus similar in the south, especially in Blekinge, most of the increase was found on Öland and Gotland and in the east coast archipelagos, especially in Kalmarsund and Östergötland.

\section{Mute Swan Cygnus olor}

The Mute Swan was distributed all over the Swedish coast, both in the archipelagos and on the open coasts. As the winter was mild, there were also large flocks on some inland lakes, especially in Scania, but also further north (Figure 24). In the west coast archipelagos the Mute Swan was well spread in smaller groups over the inner parts and sheltered areas further to the sea. In the Baltic archipelagos the swans were mostly found in small groups and in many areas in pairs spread over the entire archipelago. In the Stockholm archipelago several smaller groups and pairs were found far out at the sea close to the outermost small skerries and island.

The number of wintering Mute Swans in Sweden show the same increase as most other species discussed here. In January 2015 somewhat more than 50000 were estimated for the coast compared to 310002004 and 73001971.

The Mute Swan was found in relatively high numbers in all four regions. Simultaneous with the large increase in numbers between 1971 and 2004 there was a change in the proportion of the birds wintering in the different regions (Figure 25). More than $50 \%$ of all Mute Swans were found on the west coast and Öresund in the 1971 survey, and this proportion continued to decline between 2004 and 2015. On the other hand, less than $20 \%$ of the total was found in the Archipelago area in 1971 and 2004 compared to more than $40 \%$ in 2015 . Thus, the relative importance of the archipelago as wintering sites for Mute Swans has increased during past decades.

\section{Whooper Swan Cygnus cygnus}

Since the start of the IWC it was noted that the Whooper Swans gradually changed their habits to feed more and more on land, behaving like geese. This made it impossible to follow the population development of the species in the normal midwinter counts, so a series of special Whooper Swan surveys were started in Europe in 1995 (Laubek et al. 1999, Nilsson 1997), which has since then been repeated every five years. Thus the country-wide coastal survey in 2015 coincided with the special Whooper Swan survey in January. This survey will be discussed in a separate paper in this volume (Nilsson 2016).

\section{Great crested Grebe Podiceps cristatus}

The only common species among the grebes was the Great Crested Grebe with a total of 2700 in 2015 compared to 4300 in 2004; data are missing for 1971. Along the coasts it was distributed in flocks in the Öresund, the Hanöbukten and at the coasts of Gotland (Figure 26). In other regions the species was less abundant occurring only in smaller numbers. A large proportion of the wintering Great Crested Grebes in Sweden are known to stay in one large flock in Lundåkrabukten in Öresund. The flock often stays far out at sea and can be difficult to count from land especially in bad weather, which will cause quite marked variation in the counts between years.

\section{Heron Ardea cinerea}

The Heron was counted in relatively small numbers. It was widespread in south Sweden both at the coasts and inland (Figure 26). Herons were includ- 

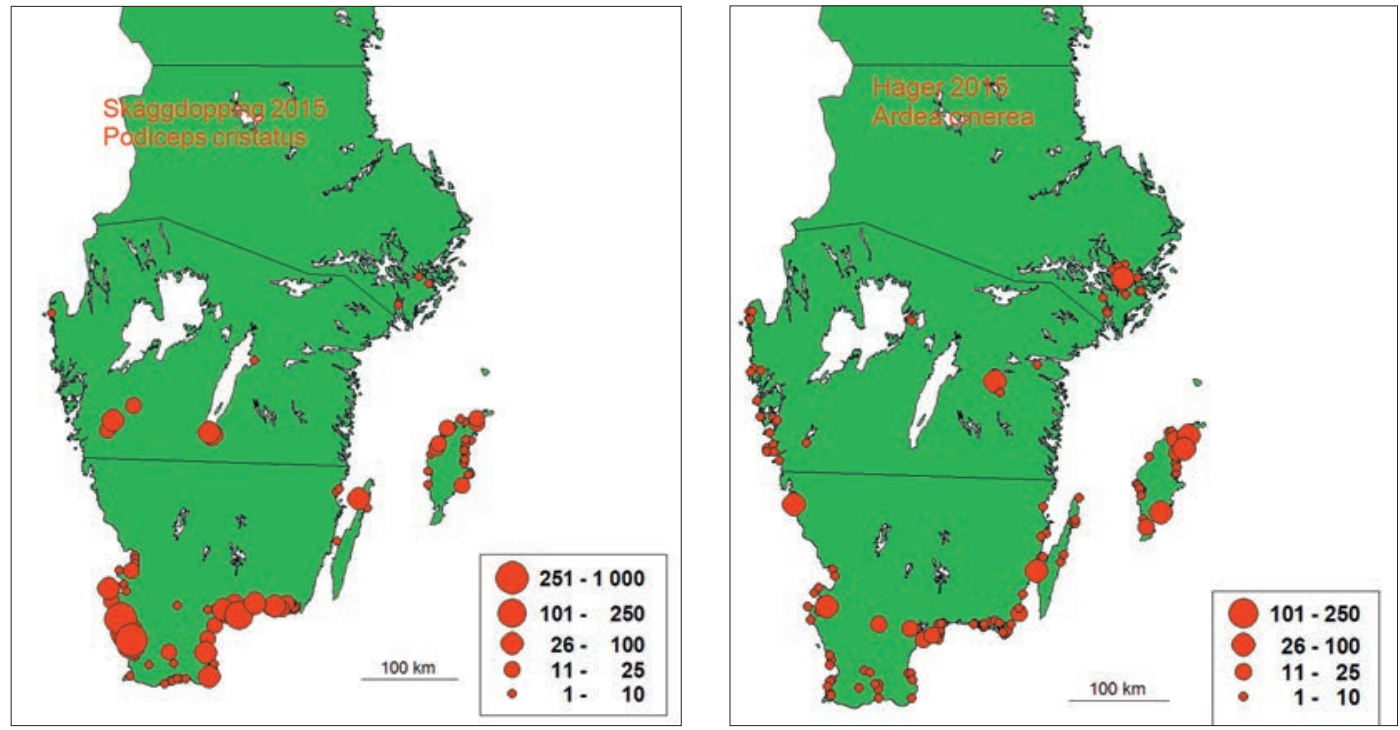

Figure 26. Midwinter distribution of Great-crested Grebe Podiceps cristatus and Heron Ardea cinerea in Sweden 2015. Midvinter utbredning för skäggdopping och häger i Sverige 2015.

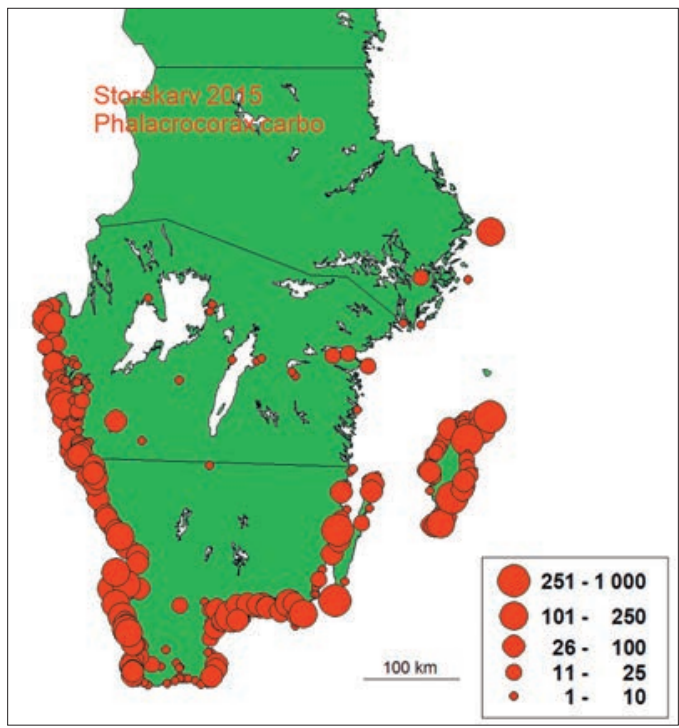

Figure 27. Midwinter distribution of Cormorant Phalacrocorax carbo in Sweden 2015 with details for a part of the Swedish west coast.

Midvinterutbredning för storskarvi Sverige 2015 med detaljer för en del av den svenska västkusten.

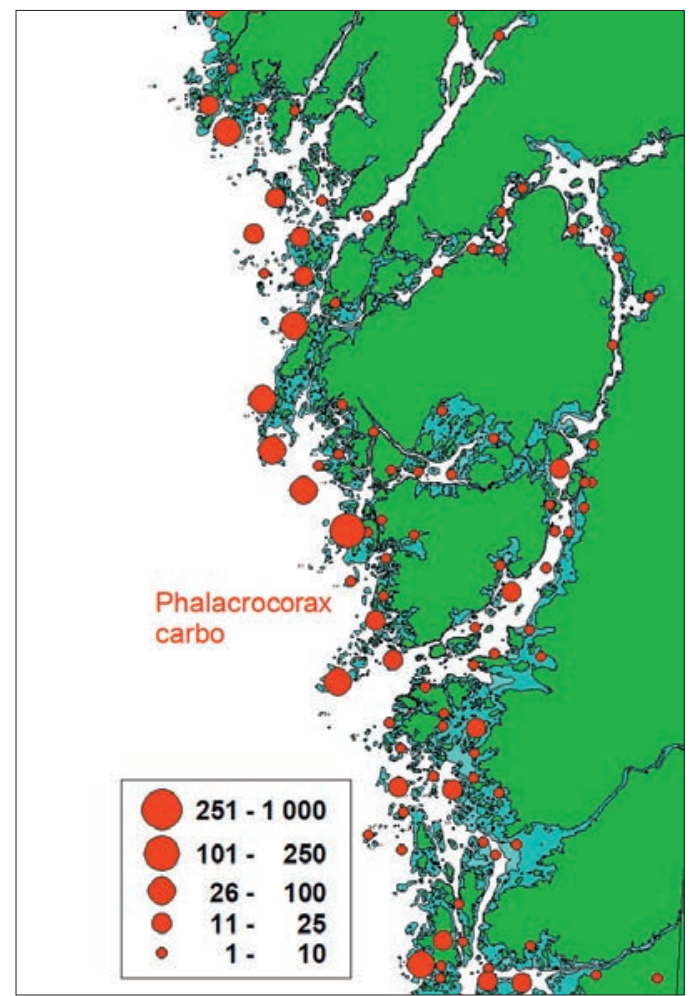




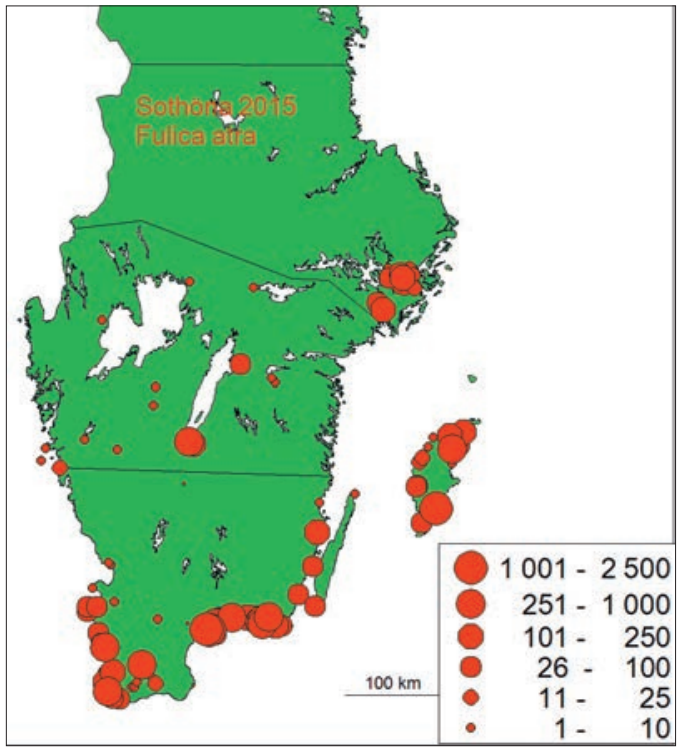

Figure 28. Midwinter distribution of Coot Fulica atra in Sweden 2015.

Midvinterutbredning för sothöna i Sverige 2015.

ed in the country-wide surveys in 2004 and 2015, when about 500 and 600 , respectively, were estimated for the coasts with smaller numbers inland.

\section{Cormorant Phalacrocorax carbo}

Cormorants were common along the west coast and the southern Baltic coasts of Sweden, whereas there were few occurrences of the species in the main Baltic archipelagos north of Kalmarsund (Figure 27). The detailed map for central Bohuslän shows that this species occurs in all coastal waters, but most of the larger groups were seen on the outermost skerries and islands. The number of wintering Cormorants in Swedish coastal waters was estimated to be 14300 in 2015 compared to 11700 in 2004 and 1000 in 1971.

\section{Coot Fulica atra}

The Coot was more or less concentrated to the southernmost coastal areas (76\%) with some occurrences along the coast of Gotland (19\%) (Figure 28). There were also some inland flocks, but no Coots were observed in the Baltic archipelagos. In 2015, 11200 Coots were estimated for the inshore coastal areas compared to 16000 in 2004 and 3900 in 1971 .
Other species

In addition to the species discussed above a number of other waterbird species have been counted in smaller numbers at the surveys in all three years but also during the annual ground based midwinter counts. For details of these species at the countrywide surveys see Tables 2-5 with a regional breakdown for 2015 in Tables A2 and A3 (see also Nilsson 2008 and the annual reports from the project, http://www.zoo.ekol.lu.se/waterfowl/index.htm, for older data).

\section{Trends in the wintering waterbird populations 1966-2015}

There is a remarkable difference between the longand short-term population trends (Table 6). In the former category 25 out of 29 species show significantly positive trends, whereas only six species show significantly positive 10 -year trends. The difference gets even more pronounced when focusing on species showing negative trends. Only one species, the Long-tailed Duck, demonstrates a longterm decline, which can be compared with the 15 species that have declined between 2006 and 2015. However, it should be emphasized that the slope of the short term trend is much more sensible for occasional years of either high or low number of birds. In this context it should be mentioned that there were two cold winters in 2010 and 2011 after

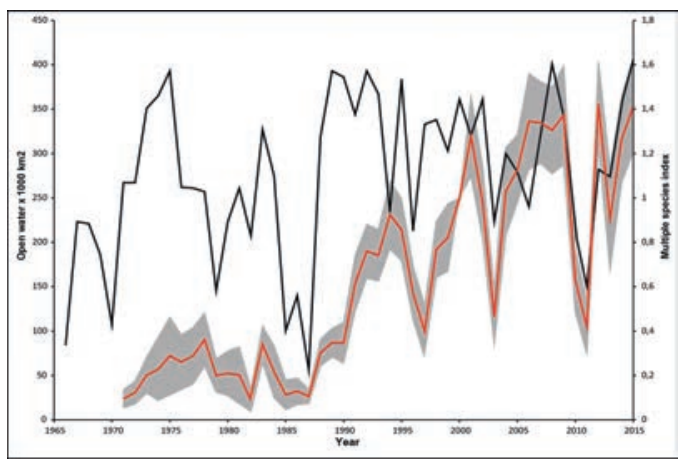

Figure 29. Multispecies index over time (red solid line) with $95 \%$ confidence interval (grey area) based on 27 waterbird species observed during the Midwinter counts. Black solid line shows the minimum area of open water during winter in Kattegat and the Baltic Sea (calculated as $420000 \mathrm{~km}^{2}$ minus maximum ice cover, cf. method).

Sammansatt index (röd linje) med 95\% konfidensintervall (grått område) baserat på 27 sjöfågelarter räknade under midvinterinventeringarna. Svart linje anger minimum arealen öppet vatten under vintern $i$ Kattegatt och Östersjön (beräknat som $420000 \mathrm{~km}^{2}$ minus maximal isutbredning (se metod!). 
Table 6. Population trends, based on the national data set, until year 2015 according to the TRIM analyses for 29 seabird species in January for the entire (E) time series for each of the species and for last ten (10) years. Green: significant $(p<0.05)$ increase; red: significant $(p<0.05)$ decrease; white: no significant trend. Starting year of the long-term time series is shown in column E. Also shown are the slope of each species trend line and the corresponding standard error.

Beståndsutvecklingen för hela Sverige fram till år 2015 enligt TRIM-analyserna för 29 sjöfågelarter i januari för respektive arts hela (E) tidsserie samt för de tio (10) senaste åren. Grönt: signifikant ökning; rött signifikant minskning; vitt: ingen signifikant trend. Tidsseriernas startår visas i kolumn E. Dessutom visas lutningskoefficienten för respektive art trendlinje och korresponderande standardfel.

\begin{tabular}{lrrrrr}
\hline & Slope (E) & S.E. (E) & Slope (10) & S.E. (10) & E 10 \\
\hline Cygnus olor & 1.030 & 0.001 & 0.982 & 0.005 & 1966 \\
Cygnus cygnus & 1.009 & 0.001 & 0.984 & 0.009 & 1966 \\
Tadorna tadorna & 1.049 & 0.025 & 0.937 & 0.045 & 1966 \\
Anas penelope & 1.179 & 0.027 & 0.971 & 0.010 & 1966 \\
Anas strepera & 1.174 & 0.031 & 1.020 & 0.032 & 1987 \\
Anas crecca & 1.078 & 0.008 & 0.952 & 0.021 & 1966 \\
Anas platyrhynchos & 1.020 & 0.001 & 1.005 & 0.004 & 1966 \\
Anas acuta & 1.105 & 0.034 & 0.866 & 0.032 & 1966 \\
Aythya ferina & 1.053 & 0.005 & 0.933 & 0.015 & 1966 \\
Aythya fuligula & 1.019 & 0.001 & 0.985 & 0.007 & 1966 \\
Aythya marila & 1.070 & 0.005 & 1.063 & 0.012 & 1966 \\
Somateria mollissima & 1.038 & 0.002 & 1.067 & 0.008 & 1966 \\
Clangula hyemalis & 0.980 & 0.001 & 0.973 & 0.009 & 1966 \\
Melanitta nigra & 1.064 & 0.005 & 1.125 & 0.020 & 1966 \\
Melanitta fusca & 0.996 & 0.004 & 1.355 & 0.047 & 1966 \\
Bucephala clangula & 1.022 & 0.001 & 1.010 & 0.004 & 1966 \\
Mergellus albellus & 1.072 & 0.004 & 1.023 & 0.011 & 1966 \\
Merganser serrator & 1.028 & 0.001 & 0.970 & 0.007 & 1966 \\
Mergus merganser & 1.011 & 0.001 & 0.981 & 0.006 & 1966 \\
Gavia stellata & 1.104 & 0.057 & 1.032 & 0.032 & 1971 \\
Gavia arctica & 1.081 & 0.011 & 0.950 & 0.027 & 1971 \\
Tachybaptus ruficollis & 1.061 & 0.005 & 0.876 & 0.018 & 1971 \\
Podiceps cristatus & 1.104 & 0.006 & 0.968 & 0.011 & 1971 \\
Podiceps grisegena & 1.052 & 0.020 & 0.926 & 0.031 & 1971 \\
Podiceps auritus & 1.071 & 0.011 & 1.080 & 0.045 & 1971 \\
Phalacrocorax carbo & 1.054 & 0.002 & 0.996 & 0.006 & 1971 \\
Ardea cinerea & 1.065 & 0.003 & 0.920 & 0.008 & 1971 \\
Fulica atra & 1.019 & 0.002 & 0.877 & 0.008 & 1966 \\
Cepphus grylle & 1.098 & 0.024 & 0.952 & 0.023 & 1998 \\
\hline & & & & & \\
\hline
\end{tabular}

a long series of mild winters, which may have influenced the short-term trends. Trend-diagrams for the different species are found in Appendix 5.

The multispecies index for 1971-2015 (Figure 29 ) shows a highly significant increase over time $\left(\mathrm{r}^{2}=0.69, \mathrm{~F}_{1,43}=97.7, \mathrm{p}<0.001\right)$, which is not the case for the period 2006-2015 $\left(\mathrm{r}^{2}=0.01, \mathrm{~F}_{1,8}=0.08\right.$, $\mathrm{p}>0.05$ ). From late $1980 \mathrm{~s}$ until the millennium shift the multispecies index shows a more or less continuous increase, thereafter the increase has flattened out. Thus, the time series indicates a period with low numbers of wintering birds (roughly between 1971 and 1987), a period with increasing numbers (1988-2000), and a period with high numbers 
Table 7. Significance of regional trends for 1971-2015 based on the midwinter counts for seven species, all widespread in coastal areas, five of them widespread also inland. Regions consist of the following areas presented in Figure 1: V (Bohuslän), AB (Kattegat), C (Öresund), D (S and E Scania), E (Blekinge), FG (Kalmarsund), HMNO (northern Kalmar county, Östergötland and Stockholm arcipelagos), K (Öland), L (Gotland). For definition of inland waters (Inland, north and south, respectively, see method). Green cells denote significant increase, red significant decline, white no significant trend and grey missing data. Significant levels are indicated as: * $=$ $\mathrm{p}<0.05, * *=\mathrm{p}<0.01, * * *=\mathrm{p}<0.001$. Slopes and s.e. are presented in appendix.

Regionala trender, baserat på data från midvinterräkningarna 1971-2015, för sju arter, alla vanliga vid kusten och fem även i inlandet. I regionerna ingår följande ytor presenterade i Figur 1: V (Bohuslän), AB (Kattegatt), $C$ (Öresund), D (Skånes syd- och ostkust), E (Blekinge), FG (Kalmarsund), HMNO (N Kalmar län, Östergötland och Stockholm), K (Öland), L (Gotland). För förklaring till uppdelningen av inlandsvatten (Inland, south och north, se metod). Grönt indikerar signifikant ökning, rött signifikant minskning, vitt ingen signifikant trend, grått data saknas. Signifikansnivåerna visas enligt följande: $*=p<0.05, * *=p<0.01, * * *=p<0.001$. Trendlinjernas lutning och standardfel presenteras $i$ appendix.

\begin{tabular}{lccccccccccc}
\hline Region & $\mathrm{V}$ & $\mathrm{AB}$ & $\mathrm{C}$ & $\mathrm{D}$ & $\mathrm{E}$ & $\mathrm{FG}$ & $\mathrm{HMNO}$ & $\mathrm{K}$ & $\mathrm{L}$ & Inland, N & Inland, S \\
\hline Anas platyrhynchos & & $* * *$ & $* * *$ & $* * *$ & $* * *$ & $* * *$ & $* * *$ & $* * *$ & $* * *$ & $* * *$ & \\
Aythya fuligula & & $* * *$ & $* *$ & $*$ & $* * *$ & $* * *$ & $* * *$ & $* * *$ & $* * *$ & & \\
Bucephala clangula & $* * *$ & $*$ & $* * *$ & $* * *$ & $* * *$ & $* * *$ & $* * *$ & $* * *$ & $* * *$ & $* * *$ & \\
Mergus serrator & & $* * *$ & $* * *$ & $* * *$ & $* * *$ & $* * *$ & & $* * *$ & & & \\
Mergus merganser & $* *$ & $* * *$ & $* *$ & & & $* * *$ & $* * *$ & $* * *$ & $* * *$ & & \\
Cygnus olor & $* * *$ & & $* * *$ & $* * *$ & $* * *$ & $* * *$ & $* * *$ & $* * *$ & $* * *$ & & \\
Fulica atra & & $* * *$ & $* *$ & $* * *$ & $* * *$ & & & & $* * *$ & & \\
\hline
\end{tabular}

(2001-2015). The multispecies index for each of the relatively stable periods, 1971-1987 and 20012015 , were both positively correlated with area of open water (Pearson's $\mathrm{r}=0.56, \mathrm{p}<0.05$ and $\mathrm{r}=$ $0.73, \mathrm{p}<0.01$, respectively. No such correlation was present for the transition period between low and high abundance of waterbirds $(\mathrm{r}=-0.13, \mathrm{p}>0.05)$. The average minimum area open water for each of the three periods was as follows; 1971-1987: $245000 \mathrm{~km}^{2}$ (s.d. = 92 500), 1988-2000: 336000 $\mathrm{km}^{2}$ (s.d. = 57 600), and 2001-2015: $297000 \mathrm{~km}^{2}$ (s.d. $=71800)$. The difference in minimum area of open water is significant between periods (one-way ANOVA, F2,42 $=5.35, \mathrm{p}<0.01$ ).

The subdivision of the national data set allowed us to do regional trends of seven species in coastal areas and five in inland areas (Table 7, Appendix 4). Not surprisingly, the regional trends show the same general picture as the national ones. But opposed to the national trends a few regions show declining numbers of some species. In Kattegat and Öresund, Tufted Ducks as well as Red-breasted Mergansers have declined significantly in numbers between 1971 and 2015. The same is true for Mute Swans in Bohuslän and European Coots in Kattegat. The declining species are restricted to the Swedish west-coast; in the Baltic Sea all species analysed here are either increasing or stable. The latter is the case also for northerly as well as southerly inland waters.

\section{Discussion}

Sweden as a wintering area for waterbirds

To evaluate the importance of Sweden as a winter area for waterbirds in the European perspective, the estimates based on the 2015 survey are compared with the population estimates published for the north-western European flyway (Table 8, Delany \& Scott 2006, Wetlands International 2015). In some cases there have been changes in the populations that have not yet been accommodated in the published population estimates but anyhow these give a background for evaluating the Swedish winter areas from an international perspective.

The country-wide survey in 2015 provides estimates of the wintering populations for most species occurring in inshore waters. To make the picture complete we have included estimates of the wintering populations of three seaducks from the offshore surveys in Swedish waters in 2009-2011 (Nilsson 2012).

For the Long-tailed Duck, two estimates are presented in Table 8, one from the mild winter of 2009 when all waters could be covered and the Swedish 
Table 8. The wintering populations of different waterfowl species in Sweden in 2015 in relation to the estimated populations for NW Europe (according to Wetlands International 2015). * = Based on offshore surveys in 2009-2011, no offshore data in 2015 (see Nilsson 2012).

Vinterbestånden av olika sjöfågelarter i Sverige 2015 jämfört med de uppskattade bestånden för NW Europa (enligt Wetlands International 2015). * = baserat på offshore inventeringar 2009-2011, ingen offshoreinventering 2015 (se Nilsson 2012).

\begin{tabular}{lrrrr}
\hline Species & NW Europe & 2015 survey & Estimate Sweden & Sweden \% \\
\hline Anas platyrhynchos & 4500000 & 87000 & $150000-200000$ & 4.4 \\
Anas crecca & 500000 & 500 & 500 & 0.1 \\
Anas penelope & 1500000 & 8700 & 9000 & 0.6 \\
Aythya marila & 310000 & 26850 & 27000 & 8.7 \\
Aythya fuligula & 1200000 & 182000 & 190000 & 15.8 \\
Aythya ferina & 300000 & 1208 & 1250 & 0.4 \\
Bucephala clangula & 1300000 & 87000 & 90000 & 6.9 \\
Clangula hyemalis* & 1600000 & - & $440000-700000$ & $27.5-43.8$ \\
Melanitta fusca* & 450000 & - & 4500 & 1.0 \\
Melanitta nigra* & 1600000 & - & 19000 & 1.1 \\
Somateria mollissima & 976000 & 51730 & 60000 & 6.1 \\
Mergus serrator & 170000 & 5196 & 9000 & 5.3 \\
Mergus merganser & 266000 & 35000 & 40000 & 15.0 \\
Mergus albellus & 40000 & 8007 & 8000 & 20.0 \\
Cygnus olor & 250000 & 50500 & 52000 & 20.1 \\
Cygnus cygnus & 60000 & 12000 & 12000 & 20.0 \\
Fulica atra & 1750000 & 11200 & 13000 & 0.7 \\
Phalacrocoarx carbo & 390000 & 14200 & 15000 & 3.8 \\
Podiceps cristatus & 360000 & 2700 & 3000 & 0.8 \\
\hline
\end{tabular}

population was estimated to be 440000 and one estimates from the cold winters of 2010 and 2011, when many areas of the Baltic were covered by ice and the wintering population of the Swedish areas covered was in the order of 700000 . The high counts in the two ice winters are most probably due to the freezing of the important wintering areas for the species in the outer parts of the Riga Bay and a subsequent move of some of these birds into Swedish waters.

For the Velvet Scoter and the Common Scoter data from 2009 have been used, but much higher numbers of Common Scoter were found during a partial survey of the southernmost offshore areas in 2007 (cf. Nilsson 2012), the total number of Velvet Scoters and Common Scoters in the offshore waters of regions $\mathrm{D}, \mathrm{F}$ and $\mathrm{K}$ (Figure 1) were then estimated to be 6150 and 39900 , respectively. It is however probable that these were temporary aggregations as such concentrations have never been seen here before. Numbers estimated from the surveys in 2009-2011 are likely to be more represent- ative for the wintering populations.

The Eider is also a typical seaduck, but the coverage of the main areas of the west coast was complete and the only area of importance for the species not covered in 2015 was the offshore waters around Falsterbo and southern Öresund with an estimated wintering population of about 10000 , a value included in the estimates in Table 8. The Red-breasted Merganser is also found in larger numbers in some offshore areas, especially around Falsterbo and in the southern Öresund (Green \& Nilsson 2015, Nilsson 2012), the estimates having been adjusted accordingly.

As presented above, some Goldeneyes and Goosanders are also staying on inland waters and smaller numbers winter along the coasts north of the areas covered in 2015 (being ice-covered during earlier surveys). The estimates from the 2015 survey (Table 8) have been adjusted to include also these birds.

Considering the Swedish coastal waters as a unit, the Long-tailed Duck is clearly the most common 
species with up to 700000 present during the cold winters of 2010 and 2011 (Nilsson 2012). For the inshore coastal waters the Tufted Duck is the most common species with a total estimated winter population of 190000 in 2015, but more than 225000 were counted in the previous country-wide survey in 2004.

When comparing the Swedish estimates with the estimates of the winter populations for the entire north-western Europe (Table 8) it is clear that Swedish waters are of great international importance for some wintering species. The offshore banks in the Swedish Economic Zone are especially important for the Long-tailed Duck, where between $27 \%$ and $44 \%$ of the estimated total population for the Baltic and for north-western Europe (cf. Skov et al. 2011) were found in Swedish waters in 2009-2011. Other species for which Sweden has a high proportion of the total north-west European winter population are Tufted Duck, Goosander, Smew, Mute Swan and Whooper Swan. For these species between $15 \%$ and $20 \%$ of the estimated wintering population in north-west Europe was found wintering in Sweden.

Sites that regularly are used by more than $1 \%$ of the estimated population for the flyway are considered to be internationally important resting/wintering sites for the species according to the Ramsar convention (Wetlands International 2015). In the same way sites that regularly hold more than 20000 waterbirds are also considered internationally important. Even if Sweden has important proportions of the wintering populations of some species, relatively few wintering sites qualify as Internationally Important Sites as most wintering waterbirds in Sweden occur quite dispersed when they are not concentrated to a few sites due to the ice conditions in cold winters.

For the most abundant waterbird in Swedish waters, the Long-tailed Duck, some offshore areas are clearly to be considered as internationally important sites. This especially applies to the Hoburg bank and the Midsjöbanks (Nilsson 2012), recent maximum counts being 426000 and 213000 Long-tailed Ducks respectively, i.e. $27 \%$ and $13 \%$ of the entire Baltic wintering population at some occasions.

Among the inshore species, internationally important wintering numbers were found on a few sites for the Tufted Duck, Smew and in some cases Goosander. For the Tufted Duck and Smew, internationally important numbers were regularly found in the Blekinge archipelago between Ronneby and Karlskrona. In mild winters such concentrations were also found in the inner parts of the archipelagos, e.g. in the Kalmarsund and Östergötland for the Smew and in the Stockholm archipelago for the Goosander and Tufted Duck, but the exact sites for the flocks varied between years due to ice conditions. However, most common inshore diving species are more dispersed. Even if flocks are sometimes surpassing the criteria it is difficult to fulfil it as it should be shown that the sites regularly hold large concentrations. This is normally not the case because the exact localization of the concentrations normally varies between times.

\section{Development of the wintering populations during the last 50 years}

The long-term trends for the wintering populations of waterbirds in Sweden over the past fifty years has been significantly increasing, with the exception of the Long-tailed Duck which was significantly decreasing, and three species that did not show any clear long-term trends: Shelduck Tadorna tadorna, Velvet Scoter and Red-throated Diver Gavia stellata. Of these three species, the Shelduck and the Red-throated Diver were only counted in small numbers. For the scoters, it is not clear if the indices presented are representative for the entire Sweden as they are based on ground counts from the shore and the majority of the Scoters are found offshore.

Among the seaducks a representative sample of the Swedish wintering population is covered by the annual counts for the Eider and the Red-breasted Merganser. The indices presented for the Longtailed Duck are based on a relatively large sample of sites where appreciable numbers of the species have been counted annually during the study period. For the Long-tailed Duck extensive data are available for the offshore areas around the mainland coast and Öland from the seventies showing a marked decrease in the wintering population of the species to the present day as was found in the indices from the ground counts (Nilsson 2012). The same pattern is indicated in restricted data available from the coasts of Gotland. For the Long-tailed Duck data from the offshore banks are available from a survey in 1992/1993 (Durinck et al. 1994) and the SOWBAS survey in 2007-2009 (Skov et al. 2011, Nilsson 2012). Taken together these data indicate a major decrease in the wintering population of Long-tailed Duck in Swedish waters.

For the seaducks an analysis of the trends for wintering waterbirds in the waters of the European Union (Nagy et al 2015) indicate a decreasing 
long-term trend. In 1992/1993, the Baltic population of Long-tailed Duck was estimated to be 4.2 million, whereas the estimate in 2007-2009 was only 1.48 million individuals, a dramatic decrease (Skov et al. 2011). Similarly, the wintering populations of the Velvet Scoter and the Common Scoter showed a marked decrease between the surveys. The surveys are made with different methods (ship-based and aerial surveys) and over long time and are therefore strictly not fully comparable but the marked decrease for the seaducks in the region is totally clear.

In the Eider the wintering population has also shown a marked decrease between the two all-Baltic surveys (Skov et al. 2011). This is also reflected in the breeding populations in the Baltic (Desholm et al. 2002, Ekroos et al. 2012). The time-series analysis presented here indicates an opposite pattern, both the long and short term trends are positive. However, this result is a bit misleading. A previous study, covering exactly the same time periods, showed that the number of over-wintering Eiders was declining on the Swedish east-coast, whereas the opposite was true for the west-coast (Nilsson \& Haas 2015). Because most Eiders winter along the west-coast the national trend presented in this study is much influenced by the situation there. The total counts of Eiders along the west coast show no major changes between the two last surveys.

The Red-breasted Merganser is also considered as a seaduck but the proportion that occurs in inshore waters during winter makes the trend estimates relevant. The SOWBAS census in 20072009 (Skov et al. 2011) indicates a major decrease of the Baltic population also in this species, which was not apparent in the national indices presented here. Moreover, the analysis in the SOWBAS project overlooked major concentrations of the species in SW Swedish waters (Green \& Nilsson 2015).

The overall trend for the waterbirds in the European Union, considering all species covered by the IWC, is increasing (Nagy et al. 2015, cf also van Roomen et al. 2012). A breakdown of the counts shows a decreasing trend for most seaducks as discussed above in a Baltic perspective. Species other than seaducks show increasing trends with the exception of the Pochard, where the European trend is decreasing. The Swedish long term trend shows an opposite direction, but during the past ten years numbers have declined

For some species recent multi-country trend data that can be compared with the Swedish data presented here have been published, but there is a marked time-lag in the analysis and publication of trend data based on the IWC in different countries. For the Mallard, Dalby et al. (2013) analysed data from the Nordic countries. In general, the trends for the breeding populations of Mallard in the different countries were increasing, whereas the midwinter trends varied between countries.

\section{Distribution of wintering waterbirds in Swedish waters in relation to climate change}

For the three diving duck species Tufted Duck, Goldeneye and Goosander, Lehikoinen et al. (2013) analysed the IWC data from a number of countries in relation to climate change and found significant increases in the northern parts, whereas decreases were found in the southern areas. Similar results were also obtained in an international analysis of the IWC count data for the Smew (Pavon-Jordan et al. 2015). Van Roomen et.al. (2012) found decreasing numbers of wintering waterbirds in the Ijsselmeer area in the Netherlands in contrast to some of the international trends.

The northward shift in winter distributions is also indicated in the Swedish data. For several species the proportion of birds wintering in the Baltic archipelagos has increased, especially when comparing the most recent census with the census in 1971. The northward shift was most probably related to the better availability of open water in the archipelagos of the Baltic in recent years.

The regional trends also show a pattern in line with this. Of the seven species included in the regional analyses all were either increasing or stable on the east coast, whereas four species showed negative trends in at least one of the west coast regions.

Over the years there have not only been changes in distribution and numbers of the wintering waterbirds, but new wintering habits have also been established. When counts started, both the Teal and the Wigeon were only seen in very small numbers at the Midwinter counts, but new wintering habits were established during the latter part of the study period. An analysis of the European IWC data for the Wigeon (Fox et al. 2016) show increasing numbers wintering in the north and decreasing winter populations in the SW but the centre of gravity for the winter population is still in the Netherlands and the UK.

It is reasonable to believe that the general increase of waterbirds wintering along the Swedish coast to some extent can be explained by the gradual reduction of areas covered by ice. Until the 
mid-1980s the number of wintering waterbirds was on an obviously lower level than during the last 15 years. The transition between these two stages took place during a time period (1988-2000) with mild winters. In contrast to the low (1971-1987) and high abundance period (2001-2015), respectively, the between year variation in multispecies index was not at all explained by the ice coverage during the transition period. This indicates that the abundance of waterbirds was at least partly limited by the availability of open water during the two periods when the wintering waterbird communities were relatively stable, but not when the wintering populations increased. Thus, it seems likely that mild winters promoted the increase of wintering birds. But this alone cannot explain the expansion of waterbirds. The number of birds has increased proportionally more than what can be explained if it was a linear relationship between bird abundance and area of open water (cf. Table 2 and Figure 29). However, the mild winters in the early seventies followed after a series of cold winters during the sixties Especially the winter of 1962/1963 was extremely cold in most parts of Europe with a high rate of mortality among waterbirds (Dobinson \& Richards 1964, Owen et al. 1986). Thus, it is likely that our study took its start when the waterfowl populations were reduced to very low numbers. If that is the case it might be that the increase of wintering waterbirds was not limited by ice coverage until a certain point, i.e. around year 2000, when the number of birds had increased to a level where they saturated most areas with open water with suitable foraging conditions. What is troublesome in this context is that our results indicate that the number of waterbirds was influence by the ice conditions also before they started to expand. With data currently available we cannot find any reasonable explanation for this.

It is highly probable that the changes seen in the wintering populations of waterbirds in Sweden with the large increase during the 1990s is an effect both of a real increase in the size of breeding populations (cf. similar trends in a number of species in Europe; Holt et.al. 2012, van Roomen et al. 2012) and changes in distribution due to the milder winters

The changes in the distribution of waterbirds in relation to the milder winters in the north can over time cause problems for the management of the waterbird populations as the localization of important concentrations might change making the present network of protected areas less accurate. Pavon-Jordan et al. (2015) analysed the interna- tional IWC data for the Smew in relation to the EU Natura 2000 network and came to the conclusion that regular national and international assessments of the network was urgent to site-safeguard networks for this and other species of waterbirds.

In this study we use large scale data of ice coverage and we bundle data from the original counting sectors before performing the analyses. One possible way to go to further increase the understanding of the dynamics of wintering waterbirds, might be to make use of small scale data, but also to include factors like water depth and various measures indicating the quality of potential feeding areas.

\section{Acknowledgements}

The International Waterfowl Counts in Sweden have over the years been supported with grants from the Swedish Environmental Protection Agency, being part of the national Swedish monitoring program. The field work has been undertaken by a large number of voluntary observers that have counted the waterbirds of their sites in many cases over decades. We sincerely thank all participants for their large efforts over the years without which the project could not have been undertaken.

\section{References}

Atkinson-Willes, G. L. 1963. Wildfowl in Great Britain. Monographs of the Nature Conservancy. 3. Her Majesty's Stationery Office, London.

Atkinson-Willes, G.L. 1969. The midwinter distribution of Wildfowl in Europe, northern Africa and southwest Asia, 1967 and 1968. Wildfowl 20: 98-111.

Dalby, L., Söderquist, P., Christensen, T.K., Clausen, P., Einarsson, A., Elmberg, J., Fox, D., Holmqvist, N., Langedoen, T., Lehikoinen, A., Lindström, Å., Lorentsen, S-H, Nilsson, L., Pöysä, H., Rintala, J., Sigfusson, A-P. \& Svenning, J-C. 2013. The status of the Nordic populations of the Mallard (Anas platyrhynchos) in a changing world. Ornis Fennica 90: 2-15.

Delany, S. \& Scott, D. 2006. Waterbird Population Estimates. Fourth Edition. Wetlands International. Wageningen, the Netherlands.

Dobinson, H.M. \& Richards, A.J. 1964. The effects of the severe winter of 1962/63 on birds in Britain. British Birds 57: 373-434.

Durinck, J., Skov, H., Jensen, F.P. \& Pihl, S. 1994. Important Marine Areas for Wintering Birds in the Baltic Sea. Ornis Consult, Copenhagen, Denmark.

Ekroos, J., Fox, A.D., Christensen, T.K., Petersen, I.K., Kilpi, M., Jonson, J.E., Green, M., Laursen, K., Cervencl, A., de Boer, P., Meissner, W., Garthe, S. \& Öst, M. 2012. Declines amongst breeding Eider Somateria mollissima numbers in the Baltic/Wadden Sea flyway. Ornis Fennica 89: 81-90.

Fox, A.D., Ebbinge, B.S, Mitchell, C., Heinicke, T., Aar- 
vak, T., Coulhoun, K., Clausen, P., Dereliev, S., Farago, S., Koffijberg, K., Kruckenberg, H., Loonen, M.J.J.E., Madsen, J., Mooij, J., Musil, P., Nilsson, L., Pihl, S., van der Jeugd, H. 2010. Current estimates of goose population sizes in western Europe, a gap analysis and assessment of trends. Ornis Svecica 20: 115-127.

Fox, A.D., Dalby, L., Christensen, T.K., Nagy, S., Balsny, T.J.S., Crowe, O., Clausen, P. Deceuninck, B., Devos, K., Holt, C.A-, Hornman, M., Keller, V., Langedoen, T., Lehikoinen, A., Lorentsen, S-H., Molina, B., Nilsson, L., Stipniece, A., Svenning, J-C. \& Wahl, J. 2016. Seeking explanations for recent changes in abundance of wintering Eurasian Wigeon (Anas penelope) in northwest Europe. Ornis Fennica 93: 12-25

Gilissen, N., Haanstra, L., Delany, S., Boere, G. \& Hagemeijer, W. 2002. Numbers and distribution of wintering waterbirds in the Western Palearctic and Southwest Asia in 1997, 1998 and 1999. Results from the International Watebird Census. Wetlands International Global Series 11. Wageningen, the Netherlands

Green, M. \& Nilsson, L. 2015. The importance of offshore areas in southern Öresnd, Sweden, for staging and wintering sea ducks. Ornis Svecica 25: 24-39.

Gregory, R.D., van Strien, A.J., Vorisek, P., Gmelig Meyling, A.W., Noble, D.G., Foppen, R.P.B. \& Gibbons, D.W. 2005. Developing indicators for European birds. Phil. Trans. R. Soc. Lond. B. 360: 269-288.

Holt, C.A., Austin, G.E., Calbrade, N.A., Mellan, H.J., Hearn, R.D., Stroud, D.A., Wotton, S.R. \& Musgrove, A.J. 2012. Waterbirds in the UK 2010/11. The Wetland Bird Survey. BTO/RSPB/JNCC, Thetford.

Joensen, A.H. 1968. Wildfowl Counts in Denmark in November 1967 and January 1968 - Methods and Results. Danish Review of Game Biology 5(5): 1-172.

Joensen, A.H. 1974.Waterfowl Populations in Denmark 1965 - 1973. A Survey of the Non-breeding Populations of Ducks, Swans and Coot and their Shooting Utilization. Danish Review of Game Biology 9(1): 1-206.

Laubek, B., Nilsson, L., Wieloch, M., Koffijberg, K., Sudfeldt, C. \& Follestad, A. 1999. Distribution, numbers and habitat choice of the NW European Whooper Swan Cygnus cygnus population: results of an international census in January 1995. Vogelwelt 120: 141-154.

Lehikoinen, A., Jaatinen, K., Vähätalo, A.V., Clausen. P., Crowe, O., Deceuninck, B., Hearn, R., Holt, C.A., Hornman, M., Kewller, V., Langedoen, T., Nilsson, L., Tomankova, I., Wahl, J. \&, Fox, A.D. Rapid climate driven shifts in wintering distributions of three common waterbird species. Global Change Biology 19: 2071-2081.

Nagy, S., Langedoen, T. \& Flink, A. 2015. A Pilot Wintering Waterbird Indicator for the European Union. A report by Wetlands International European Association.

Nilsson, L. 1968. Seasonal Fluctuations in Numbers of Swedish Winter Ducks. Vår Fågelvärld 27: 142-171.

Nilsson, L. 1972. Habitat Selection, Food Choice and Feeding Habits of Diving Ducks in Coastal Waters of South Sweden during the Non-breeding Season. Ornis Scandinavica 3: 55-78.

Nilsson, L. 1975. Midwinter distribution and numbers of Swedish Anatidae. Ornis Scandinavica 6: 83-107.

Nilsson, L. 1976. Monthly counts as a measure of population changes in some species of Anatidae in south Sweden. Ornis Scandinavica 7: 193-205.
Nilsson, L. 1980. De övervintrande alfåglarnas Clangula hyemalis antal och utbredning längs den svenska kusten. Vår Fågelvärld 39: 1-14.

Nilsson, L. 1997. Changes in numbers and habitat utilization of wintering Whooper Swans Cygnus cygnus in Sweden 1964 - 1997. Ornis Svecica 7: 133-142.

Nilsson, L. 2008. Changes of numbers and distribution of wintering waterfowl in Sweden during forty years, $1967-$ 2006. Ornis Svecica 18: 135-226.

Nilsson, L. 2012. Distribution and numbers of wintering sea ducks in Swedish offshore waters. Ornis Svecica 22: 39-60.

Nilsson, L. 2013. Censuses of autumn staging and wintering goose populations in Sweden 1977/1978 - 2011/2012. Ornis Svecica 23: 3-45.

Nilsson, L. 2014. Long-term trends in the number of Whooper Swans Cygnus cygnus breeding and wintering in Sweden. Wildfowl 64: 197-206.

Nilsson, L. 2016. Census of wintering Whooper Swans Cygnus cygnus in Sweden January 2015. Ornis Svecica 26: 55-60.

Nilsson, L. \& Haas, F. 2015. Inventering av sjöfåglar, gäss och sångsvanar i Sverige. Årsrapport för 2014/2015. Report, Lund University.

Owen, M., Atkinson-Willes, G.L., Salmon, D.G. 1986. Wildfowl in Great Britain. Second Edition. Cambridge University Press, Cambridge, UK

Pannekoek, J. \& van Strien, A.J. 2001. TRIM 3 Manual. Trends and Indices for Monitoring Data. Research Paper No. 0102. Statistics Netherlands, Voorburg, the Netherlands.

Pavon-Jordan, D., Fox,A.D., Clausen, P., Dagys, M. Deceuninck, B., Devos, K., Hearn, R.D., Holt, C.A., Hornman, M., Keller, V., Langedoen, T., Lawickii, L., Lorentsen, S.H., Luigujoe, L., Meissner, W., Musil, P., Nilsson, L., Paquet, J-Y., Stipniece, A., Stroud, D.A., Wahl, J., Zenaqtello, M. \& Lehikoinen, A. 2015. Climate-driven changes in winter abundance of a migratory waterbird in relation to EU protected areas. Diversity and Distributions 1-12.

Skov, H., Heinänen, S., Zydelis, R., Bellebaum, J., Bzoa, S., Dagys, M., Durinc, J., Garthe, S., Grishanov, G., Hario, M., Kieckbusch, J.J., Kube, J., Kuresoo, A., Larsson, K., Luigujoe, L. Meisner, W., Nehls, H.W., Nilsson, L., Petersen, I.K., Roos, M.M., Pihl, S., Sonntag, N., Stock, A. Stipniece, A. \& Wahl, J. 2011. Waterbird Populations and Pressures in the Baltic Sea. TemaNord 2011: 550.

SMHI 2015a. Is på sjöar och vattendrag. URL: http://www. smhi.se/klimatdata/hydrologi/is-pa-sjoar-och-vattendrag, visited 2015-12-15.

SMHI 2015b. Klimatindikatorer - havsis. URL: http://www. smhi.se/klimatdata/oceanografi/havsis/klimatindikatorhavsis-1.20049, visited 2015-12-15.

Van Roomen, M., Hornman, vM., Flink, S., Langedoen, T., van Vinden, E., Nagy, S. \& van Tumhot, C. 2012. Flyway trends for waterbird species important in Lakes Ijsselmeer and Markermeer. Sovon-rapport 2012/22. Sovon Dutch Centre for Field Ornithology, Nijmegen, the Netherlands.

Wetlands International 2015. "Waterbird Population Estimates”. Retrieved from http://wpe.wetlands.org on $7 \mathrm{Dec}$ 2015. 


\section{Svensk sammanfattning}

Samordnade sjöfågelinventeringar har förekommit i Europa sedan januari 1967, då de internationella midvinterinventeringarna av sjöfågel startade $\mathrm{i}$ ett antal länder inkl. Sverige (Atkinson-Willes 1969, Nilsson 1975, Nilsson 2008). Tidigare förekom nationella inventeringar $\mathrm{i}$ ett antal länder, även Sverige. I Sverige hade en midvinterinventering av sjöfåglar genomförts redan 1966. Syftet med inventeringarna var främst att få en uppfattning om de olika sjöfågelarternas bestånd regionalt och globalt samt att följa förändringar i bestånden av olika arter. Ett annat viktigt syfte var att studera arternas utbredning och förändringar i densamma samt att ge underlag för bedömning av skyddsbehov för sjöfåglarna och deras lokaler kopplat till internationella konventioner såsom Våtmarkskonventionen och AEWA (African-Eurasian Waterfowl Agreement).

De första årens inventeringar avsåg att åstadkomma så stor täckning som möjligt av de olika arternas utbredningsområde (Nilsson 1975). För att nå målet organiserades flyginventeringar efter de svenska kusterna under 1971-1973. Det stod emellertid tidigt klart att det inte var möjligt att nå en landsomfattande täckning och inventeringarna koncentrerades därför till att täcka ett representativt urval av lokaler varje år för att kunna beräkna beståndsindex för de olika arterna. En ny landsomfattande inventering av de inre farvattnen genomfördes 2004, medan heltäckande inventeringar av vissa regioner ägde rum 1987-1989 (Nilsson 2008). De yttre farvattnen täcktes fullständigt första gången under 2007-2011, men regionala inventeringar förekom också på 1970-talet (Nilsson 2012).

2015 organiserades åter en landsomfattande inventering av de inre farvattnen mellan den norska gränsen och norra delen av Stockholms skärgård. I denna uppsats analyserar vi resultaten från denna inventering i jämförelse med de båda tidigare storinventeringarna. Dessutom presenteras en serie beståndsindex på nationell och regional nivå för de viktigaste arterna för perioden 1966-2015.

\section{Material och Metodik}

Sjöfågelinventeringarna genomförs i huvudsak med hjälp av frivilliga inventeringarna. Inventeringarna organiseras vid den helg som ligger närmast den 15:e januari varje år med veckan före och efter som reservtid. Landets kuster delades tidigt in i ett stort antal räkningssektorer, vilka var så pass små att de kan täckas av en observatör under en och samma dag. Från och med 1980-talet organiserades inventeringarna kring ett antal referensområden (Figur 1, Tabell 1) inom vilka samma lokaler inventerades på samma sätt varje år för att ge underlag för indexberäkningar. Därutöver inventerades också ett antal mindre lokaler spridda över landet.

Vid den landsomfattande inventeringen 2015 inventerades skärgårdarna med flyg. Vi använde en tvåmotorig, högvingad CESSNA 337 för inventeringarna. Flyghöjden var normalt ca $70 \mathrm{~m}$ och hastigheten vid inventeringarna $150-180 \mathrm{~km} / \mathrm{tim}$. Två observatörer täckte var sin sida av flygplanet. Observationerna registrerades med tidsangivelse och positionen för varje observation fastställdes med GPS.

I Bohuslän samt Kalmarsund sökte vi igenom aktuella vattenområden genom att cirkla runt öar och vikar och spana av de grunda områdena. Denna metodik hade tidigare år också använts i ostkustens skärgårdsområden. Eftersom 2015 var en mild isfri vinter var de områden i skärgårdarna som skulle täckas omfattande, varför inventeringarna genomfördes som linjetaxeringar spridda över området. Inventeringslinjer lades ut med $4 \mathrm{~km}$ lucka över det aktuella området och navigering skedde med hjälp av GPS. Observatörerna täckte $200 \mathrm{~m}$ på vardera sidan av flygplanet. På grund av en död vinkel under planet kom täckningen vid denna typ av inventering att bli $320 \mathrm{~m}$ av totalt $4000 \mathrm{~m}$, varför det räknade antalet fåglar multiplicerades med en faktor 12,5 för att ge en uppskattning av beståndet inom olika större områden.

Inventeringarnas täckningsgrad vid de årliga inventeringarna framgår av Figur 2. Under de senaste tio åren inventerades mellan 644 och 944 lokaler vid de årliga landbaserade inventeringarna. För ytterligare information rörande täckningsgraden hänvisas till Tabell A1. Flyginventeringarnas täckning 2015 visas i Figur 3, medan Figur 4 visar läget för linjetaxeringarna i skärgårdarna.

\section{Indexberäkningar}

Vi beräknade populationstrender för 29 arter på nationell skala och för ett färre antal arter på regional skala. På såväl nationell som regional nivå beräknades en långtidstrend, som längst sträckte sig tillbaka till 1966. Nationellt skattades även en korttidstrend (2006-2015). Med hjälp av programvaran TRIM (TRends \& Indices for Monitoring data, www.ebcc.info ) beräknades årliga artindex, som i sin tur utgjorde basen för att räkna ut den årliga genomsnittliga förändringstakten. Den senare 

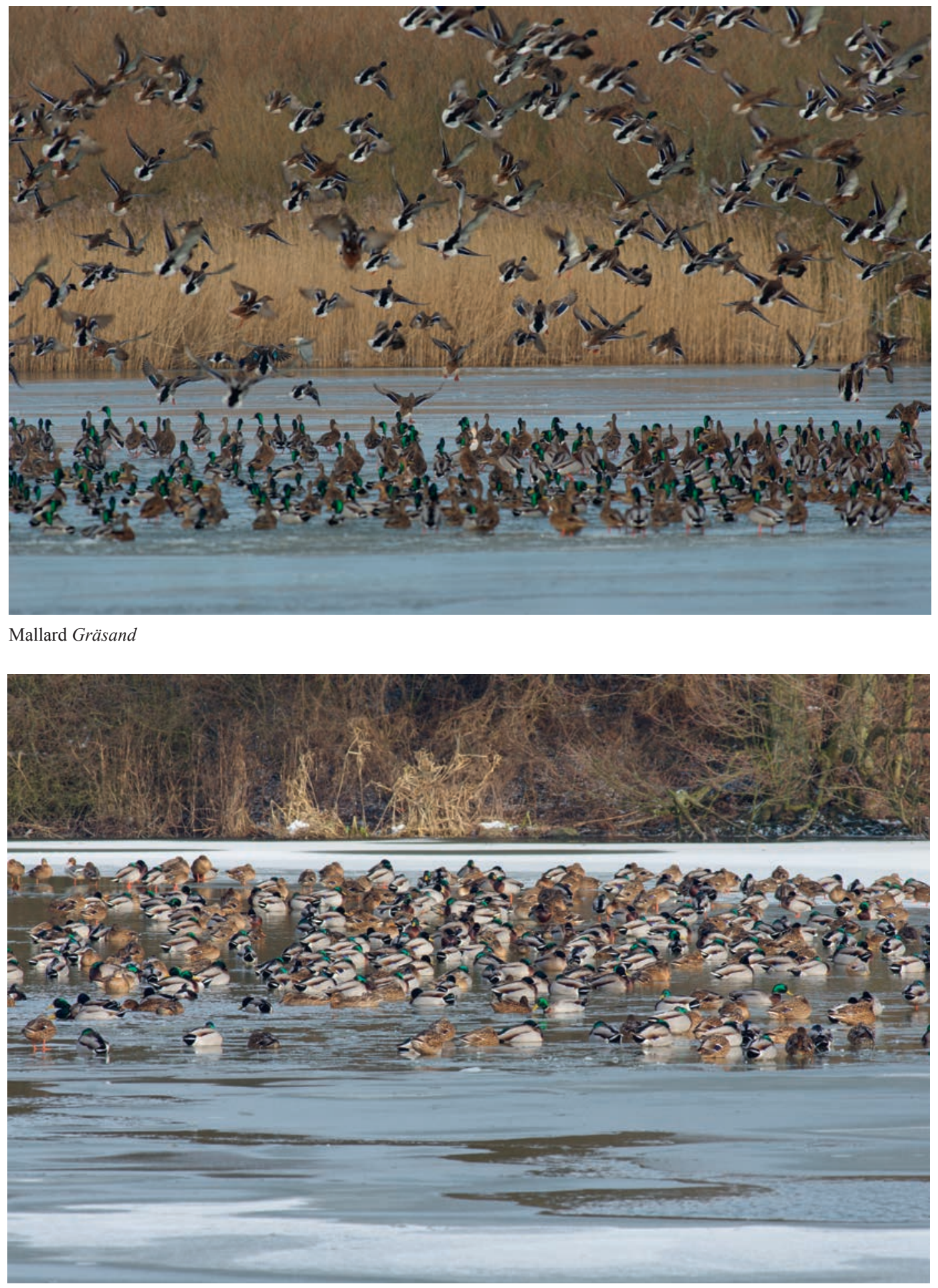
beräkningen antar att förändringen är linjär, vilket är ett antagande som inte stämmer för alla arter. TRIM-analyserna baseras på en loglinjär Possion regression som är särskilt utvecklad för att beräkna tidsserier från antalsdata. TRIM har den fördelen att klara av att hantera omständigheter som är vanligt förekommande i fågelövervakningssammanhang, exempelvis att alla inventeringsområden inte inventeras varje år (missing data). Utöver de artspecifika trendanalyserna räknade vi ut ett flerartsindex baserat på 27 arter. Detta gjordes genom att för vart och ett av åren mellan 1971 och 2015 beräkna det geometriska medelvärdet av de ingående arternas årliga index.

\section{Väderlek och isförhållanden}

Sjöfåglarna i de inre farvattnen är starkt beroende av förekomsten av öppet vatten. För att belysa vinterns olika hårdhet mellan åren har vi använt två olika mått, dels medeltemperaturen för januari beräknat för tio meterologiska stationer spridda över södra Sverige (Figur 5), dels omfattningen av den maximala isläggningen i Östersjön under olika vintrar (Figur 6).

Båda indikatorerna på vinterns hårdhet visar att vintrarna generellt har varit mildare under den senare delen av de 50 år inventeringarna pågått. Före 1987, som var den kallaste vintern under perioden noterades flera kalla vintrar, medan endast en riktigt kall vinter förekom under den senare delen av inventeringsperioden. Fram till och med 1987 noterades sex vintrar med ett maximalt istäcke $\mathrm{i}$ Östersjön på över $250000 \mathrm{~km} 2$, medan det endast förkom en sådan vinter senare.

\section{Antal och utbredning för övervintrande sjöfåglar 2015}

Vid inventeringen vintern 2015 beräknades antalet övervintrande sjöfåglar i de inre svenska kustvattnen till 616000 . I detta antal ingår inte de tre havslevande arterna alfågel, svärta och sjöorre, vilka har sin huvudsakliga utbredning till havs. Ejdern ingår däremot i detta antal eftersom merparten av ejdrarna finns i de områden som täcks av inventeringen. Det övervintrande beståndet för de olika arterna framgår av Tabell 2, som också redovisar antalet sjöfåglar vid de två tidigare landsomfattande inventeringarna 1971-1973 och 2004. Inventeringen 2015 torde ha underskattat några arter såsom knipa och storskrake eftersom täckningen var densamma som på 1970-talet och 2004, då områdena längs norrlandskusten var isbelagda. 2015 fanns det mycket öppet vatten och förmodligen också en del fågel här.

Skillnaden i totalantal sjöfåglar 2015 och 2014 var inte särskilt stor, ca 50000 färre 2004. Däremot förekom betydande skillnader för några arter, särskilt markant var detta för berganden, där nästan tio gånger så många bergänder fanns i landet 2015 jämfört med 2004, de allra flesta på Gotland. Både knipan och storskraken var också mer vanligt förekommande 2015 än 2004, medan förhållandet var det motsatta för viggen. Vid inventeringarna 1971-1973 var det övervintrande antalet sjöfåglar efter kusterna (i de inre farvattnen) betydligt lägre än 2004 och 2015, endast 174000.

Antalet övervintrare inom tre grupperingar av regioner redovisas i Tabellerna 3-5 (jämför också Figur 1 för regionindelning). Inom alla tre grupperingarna var antalet övervintrare mycket högre 2004 och 2015 än under 1971-1973. I Bohuslän var antalet ca 5 gånger högre vid den senaste inventeringen, däremot var skillnaderna inte så stora mellan 2004 och 2015. I de inre farvattnen i södra Sverige var förändringarna i antalet övervintrande sjöfåglar mellan 1971-1973 och slutet av 1980-talet ganska måttliga, men sedan skedde en markant ökning. Ökningen av antalet övervintrare var särskilt markant i ostkustens skärgårdar, där det fanns mellan fyra och sex gånger så många övervintrare jämfört med 1970-talet.

Regionala summor från inventeringen 2015 återfinns i Appendix 2 och Appendix 3. Motsvarande summor från tidigare inventeringar har publicerats i Nilsson (2008).

\section{De olika arterna}

För de vanligaste sjöfågelarterna redovisas utbredningen under vintern $2015 \mathrm{i}$ en serie kartor Figur 7-28). Jämförbara kartor från de landsomfattande inventeringarna 1971-1973 och 2004 återfinns i Nilsson (2008). För vissa skärgårdsarter visas också detaljutbredningen inom tre skärgårdsregioner i speciella kartor (Mellersta Bohuslän, Kalmar-Östgöta läns skärgård samt Stockholms skärgård).

Förändringar i utbredningen för några viktiga arter framgår förutom genom att jämföra de publicerade kartorna i denna uppsats med tidigare publicerade kartor (Nilsson 2015) i en serie diagram som visar det totala sjöfågelbeståndets fördelning på fyra storregioner (Väst, Syd, Skärgård och de Stora öarna; se Figur 1). Diagrammen återfinns i anslutning till respektive arts kartredovisning. 


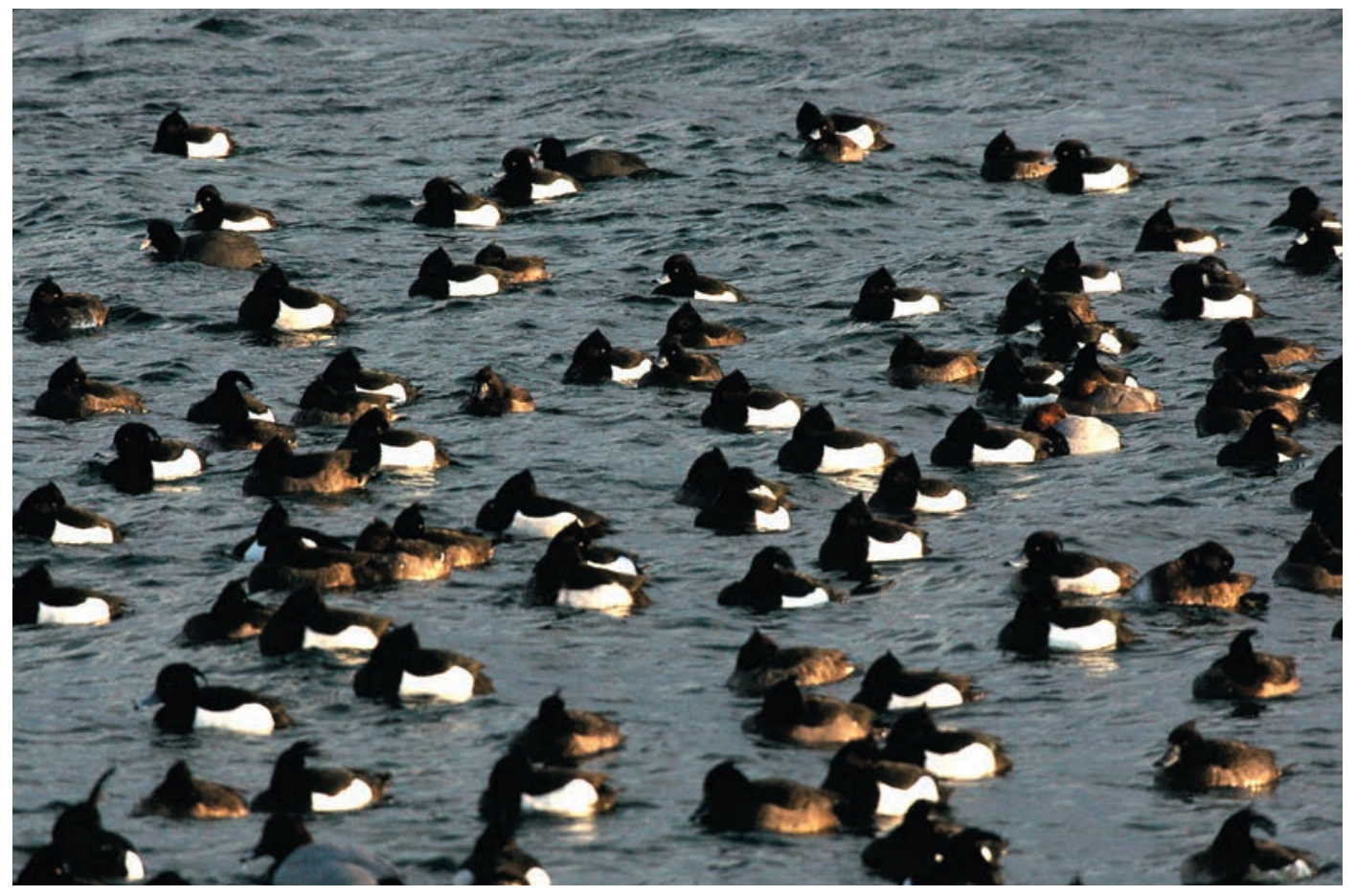

Tufted Duck Vigg

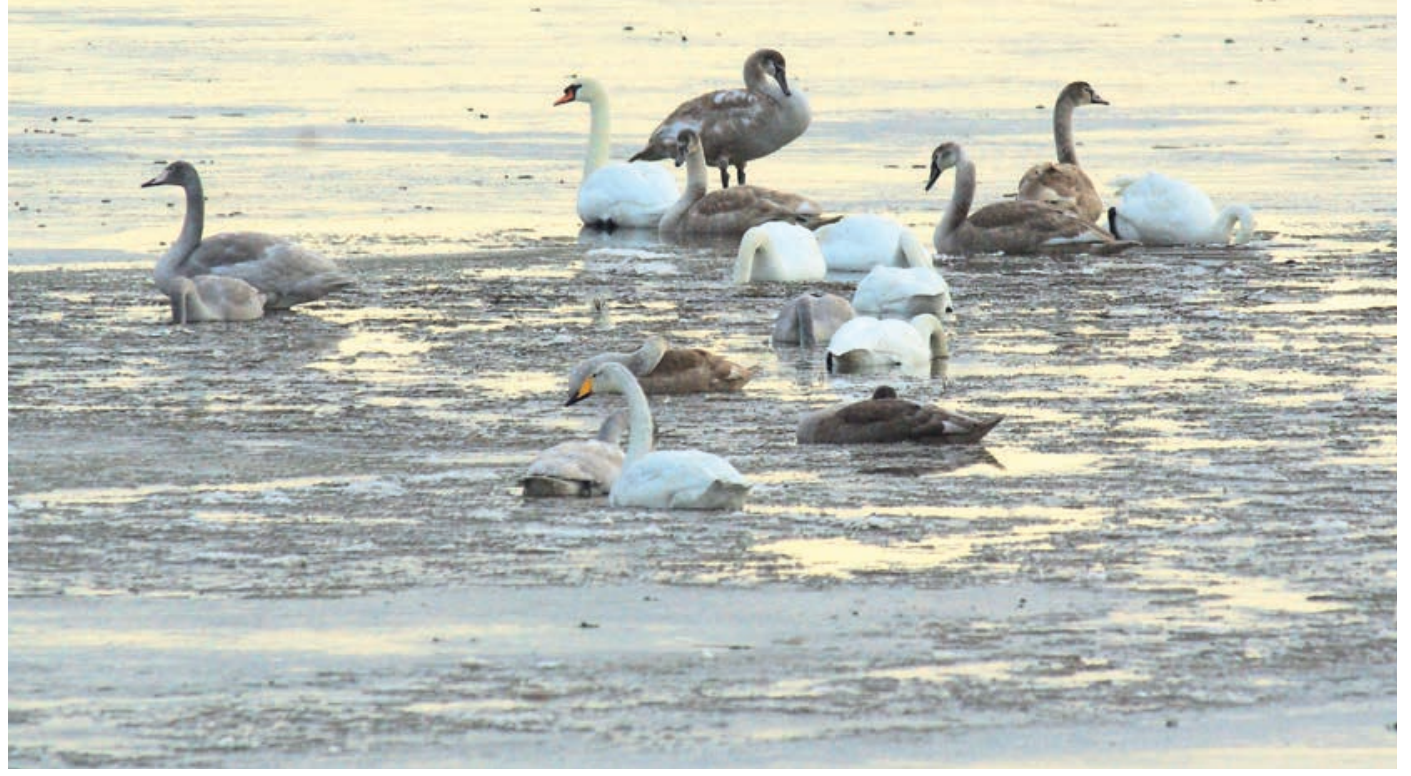

Whooper and Mute Swan Sång- och knölsvan 
Trender hos de övervintrande sjöfågelbestånden 1966-2015.

Långtidstrenderna för 25 av de 29 arterna som analyserats på nationell nivå är signifikant positiva, vilket kontrasterar mot korttidstrenderna där 15 av arterna uppvisar negativ utveckling (Tabell 6). Endast en art, alfågeln, har minskat både i det korta och långa perspektivet. De enskilda arternas trendkurvor visas i Appendix 5.

Flerartsindexet (Figur 29) understryker skillnaden mellan lång- och korttidsutvecklingen. Mellan 1971 och 2015 är flerartstrenden starkt positivt ( $\mathrm{r} 2=0,69, \mathrm{~F} 1,43=97,7, \mathrm{p}<0,001)$, vilket inte är fallet för perioden $2006-2015$ ( $2=0,01, \mathrm{~F} 1,8=0,08$, $\mathrm{p}>0,05)$. I Figur 29 visas även den minsta arealen öppet vatten under respektive vinter i Kattegatt och Östersjön. Från början av 1990-talet och framåt är det uppenbart att flerartsindexet påverkas av issituationen, det mönstret är inte lika tydligt dessförinnan.

Trenderna mellan 1971 och 2015 analyserades för sju arter på regional nivå i kustområdena och för fem i inlandet (Tabell 7, Tabell A4). Dessa trender är i stor grad samstämmiga med de nationella, men med några undantag. Vigg och småskrake har minskat signifikant i Kattegatt och Öresund. Likaså minskar knölsvanen i Bohuslän och sothönan i Kattegatt. I Östersjön och inlandet visar samtliga arter antingen ökande eller stabila trender.

\section{Diskussion}

Sverige som ett övervintringsområde för sjöfåglar

För att belysa Sveriges betydelse som övervintringsområde för sjöfåglar ur ett europeiskt perspektiv har vi jämfört skattningarna från 2015 års inventering med publicerade skattningar för den nordvästeuropeiska regionen (Wetlands International 2015). Eftersom inventeringen endast omfattar de inre farvattnen har vi kompletterat dessa data med resultaten från den senaste inventeringen av de yttre farvattnen (2009-2011) i bedömningen (Nilsson 2012). Resultaten från jämförelserna sammanfattas i Tabell 8.

För alfågeln anger vi två skattningar för de svenska farvattnen: 440000 för den milda vintern 2009 och ca 700000 för de kalla vintrarna 2010 och 2011. Dessa båda vintrar var Rigabukten och den baltiska kusten i stort sett isbelagda och alfåglarna därifrån var tvungna att söka sig till andra områden. När det gäller svärta och särskilt sjöorre var antalet övervintrare i de svenska farvattnen ovanligt högt (Nilsson 2012) och vi använder därför skattningarna från 2010 och 2011 i jämförelserna. Ejdern är också att anse som en havslevande dykand, men för denna art täckte inventeringarna de viktigaste områdena på västkusten, men kanske 10000 övervintrare från Falsterbo området saknades.

Sammantaget för både kustnära och yttre farvatten så var alfågeln den vanligaste arten i de svenska farvattnen. För de inre farvattnen var viggen vanligast med 190000 vintern 2015 och inte mindre än 2250002004.

Mellan 27\% och $44 \%$ av Östersjöns alfåglar återfanns i de svenska farvattnen vid inventeringarna 2009-2011 (jfr. Skov et al. 2011). Andra arter där Sverige hyste en betydande andel av det nordvästeuropeiska beståndet var vigg, storskrake, salskrake, knölsvan och sångsvan. Enligt våtmarkskonventionen klassas ett område som regelbundet utnyttjas av minst $1 \%$ av den regionala populationen som ett internationellt betydelsefullt område. För de flesta övervintrande sjöfåglar är sådana områden sparsamt förekommande efter de svenska kusterna eftersom det sker en hel del rörelser beroende på isförhållandena. Några sådana koncentrationer har dock påträffats för arter som vigg, storskrake och salskrake. För en art som alfågeln är Midsjöbankarna och Hoburgs Bank utanför Gotland helt klart att betrakta som internationellt viktiga med upp till $27 \%$ resp. $13 \%$ av hela beståndet för Östersjön.

Utvecklingen i sjöfågelbestånden de senaste 50 åren

Långtidstrenderna för de övervintrande sjöfågelbestånden i Sverige har i princip varit signifikant ökande för alla arter utom alfågeln, som visat en signifikant nedåtgående trend samt tre andra arter (gravand, svärta och smålom) som inte visar någon klar trend. Indexvärdena föralfågel baseras på inventeringar från land, men inventeringarna av de yttre havsområdena visar samma mycket negativa utveckling.

En internationell analys av trenderna i de övervintrande sjöfågelbestånden inom EU (Nagy et al 2015) visar generellt en uppåtgående trend för flertalet arter med undantag för de havslevande dykänderna där den totala trenden är starkt nedåtgående. En annan art som visar en nedåtgående trend för hela EU är brunanden. 
Sjöfåglarnas utbredning i de svenska farvattnen i relation till klimatförändringar

Internationella analyser för vigg, knipa och storskrake (Lehikoinen et al. 2013) samt salskrake (Pavon-Jordan et al. 2015) visar klart att det skett stora förändringar i utbredningen av de övervintrande bestånden, markanta minskningar har konstaterats i den södra delen av det gamla vinterområdet samtidigt som ökningar i bestånden registrerats i norr.

En förskjutning av vinterutbredningen norrut kan också konstateras i det svenska materialet med mycket markanta ökningar av den andel som övervintrar i skärgårdarna. Antalet övervintrare av de olika arterna i de sydligare delarna av landet har varit konstant eller ökat något, medan flertalet arter ökat mycket markant i Östersjöns skärgårdar, där ökningen varit mycket större än den ökning som noterats för de nationella resultaten.

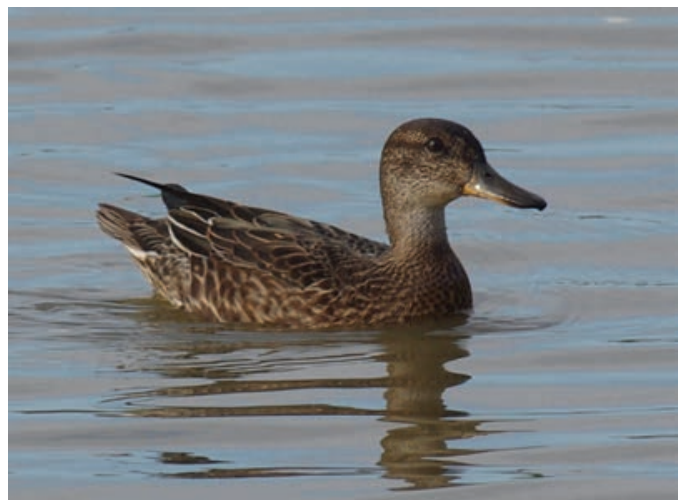

Teal

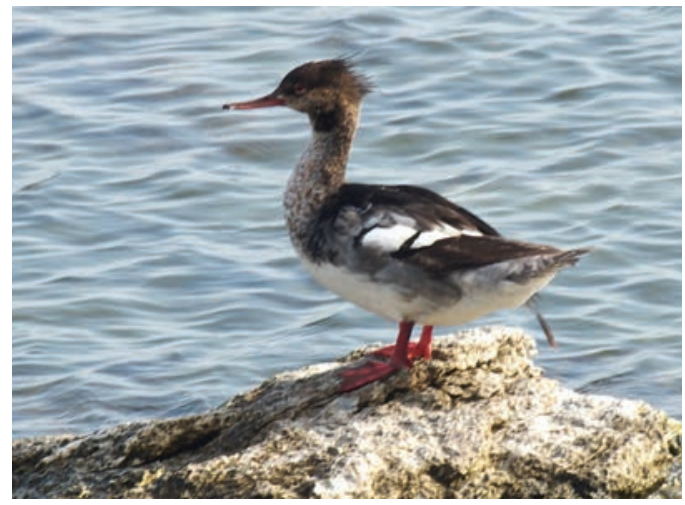

Red-breasted Merganser
Förutom de förskjutningar som skett $\mathrm{i}$ vinterutbredningen för flera sjöfågelarter har också nya övervintringstraditioner etablerats i landet. När inventeringarna startade sågs endast enstaka krickor och bläsänder, men nu har en övervintringstradition utbildats och båda arterna har övervintrande bestånd i sydligaste Sverige.

De pågående förändringarna i de övervintrande sjöfåglarnas utbredning som ett svar på de mildare vintrarna kan medföra problem för skötseln av andfågelpopulationerna. Den ändrade utbredningen kan medföra att fåglarnas vinterutbredning inte längre sammanfaller med fördelningen av skyddade områden. Pavon-Jordan et al. (2015) har uppmärksammat detta problem $i$ en analys av salskrakens vinterutbredning och funnit att det är viktigt att snarast se över nätverket av Natura-2000 områden så att det bättre överensstämmer med fåglarnas utbredning.

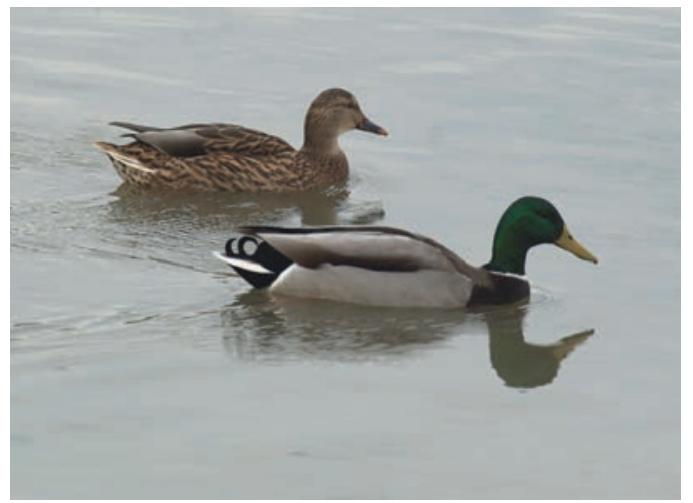

Mallard

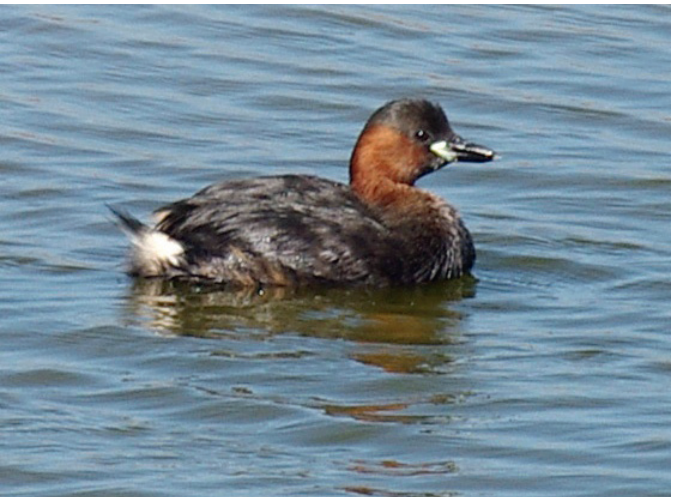

Little Grebe 
Appendix 1.

Total number of sites covered at the ground-based midwinter counts in Sweden in different years split on coastal and inland sites.

Antalet lokaler täckta vid de landbaserade midvinterinventeringarna i Sverige olika år uppdelat på kust och inlandslokaler.

\begin{tabular}{|c|c|c|c|c|c|c|c|}
\hline $\begin{array}{l}\text { Year } \\
\text { Ar }\end{array}$ & $\begin{array}{l}\text { Coast } \\
\text { Kust }\end{array}$ & $\begin{array}{l}\text { Inland } \\
\text { Inland }\end{array}$ & $\begin{array}{l}\text { Total } \\
\text { Summa }\end{array}$ & $\begin{array}{l}\text { Year } \\
\text { Ar }\end{array}$ & $\begin{array}{l}\text { Coast } \\
\text { Kust }\end{array}$ & $\begin{array}{l}\text { Inland } \\
\text { Inland }\end{array}$ & $\begin{array}{l}\text { Total } \\
\text { Summa }\end{array}$ \\
\hline 1966 & 109 & 19 & 128 & 1991 & 459 & 168 & 627 \\
\hline 1967 & 234 & 121 & 355 & 1992 & 392 & 173 & 565 \\
\hline 1968 & 215 & 179 & 394 & 1993 & 476 & 183 & 659 \\
\hline 1969 & 475 & 218 & 693 & 1994 & 458 & 187 & 645 \\
\hline 1970 & 402 & 264 & 666 & 1995 & 486 & 190 & 676 \\
\hline 1971 & 1318 & 309 & 1627 & 1996 & 486 & 157 & 643 \\
\hline 1972 & 1311 & 401 & 1712 & 1997 & 491 & 165 & 656 \\
\hline 1973 & 1240 & 447 & 1687 & 1998 & 520 & 151 & 671 \\
\hline 1974 & 891 & 283 & 1174 & 1999 & 466 & 145 & 611 \\
\hline 1975 & 818 & 307 & 1125 & 2000 & 476 & 161 & 637 \\
\hline 1976 & 840 & 293 & 1133 & 2001 & 460 & 161 & 621 \\
\hline 1977 & 827 & 206 & 1033 & 2002 & 477 & 152 & 629 \\
\hline 1978 & 773 & 212 & 985 & 2003 & 486 & 141 & 627 \\
\hline 1979 & 439 & 192 & 631 & 2004 & 687 & 331 & 1018 \\
\hline 1980 & 393 & 175 & 568 & 2005 & 532 & 153 & 685 \\
\hline 1981 & 407 & 131 & 538 & 2006 & 547 & 170 & 717 \\
\hline 1982 & 433 & 120 & 553 & 2007 & 722 & 222 & 944 \\
\hline 1983 & 397 & 109 & 506 & 2008 & 568 & 217 & 785 \\
\hline 1984 & 317 & 92 & 409 & 2009 & 550 & 193 & 743 \\
\hline 1985 & 336 & 79 & 415 & 2010 & 502 & 197 & 699 \\
\hline 1986 & 359 & 76 & 435 & 2011 & 417 & 211 & 628 \\
\hline 1987 & 1694 & 223 & 1917 & 2012 & 538 & 191 & 729 \\
\hline 1988 & 787 & 456 & 1243 & 2013 & 580 & 187 & 767 \\
\hline 1989 & 832 & 405 & 1237 & 2014 & 530 & 168 & 698 \\
\hline 1990 & 464 & 219 & 683 & 2015 & 486 & 158 & 644 \\
\hline
\end{tabular}

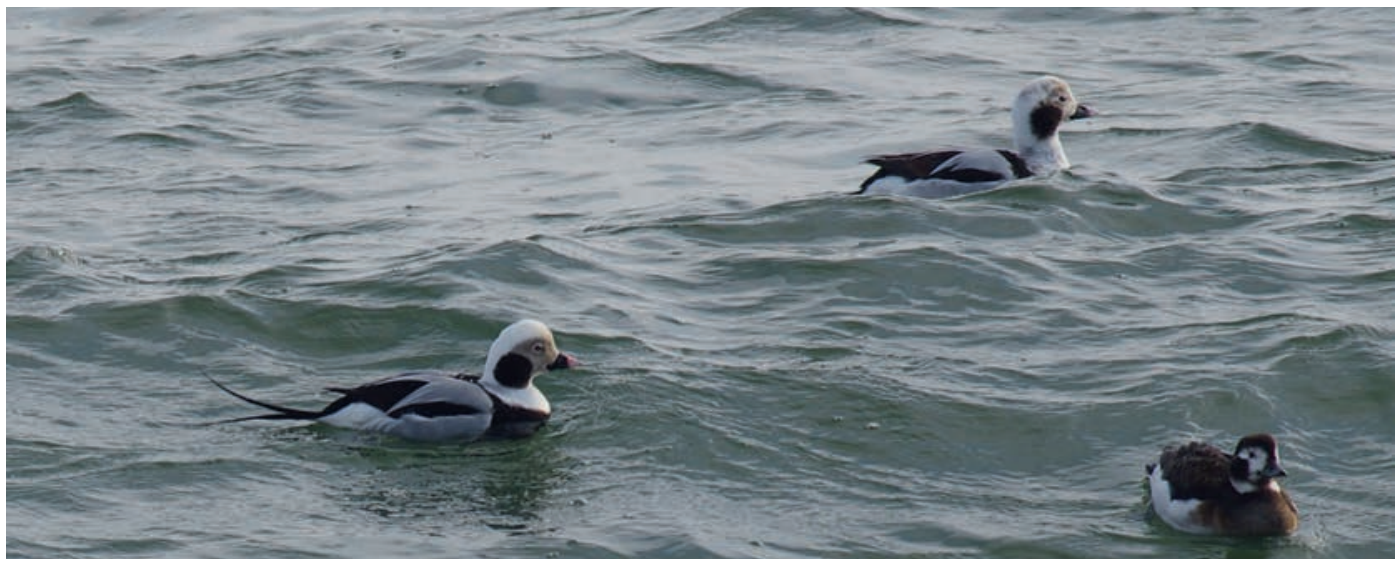

Long-tailed Duck 


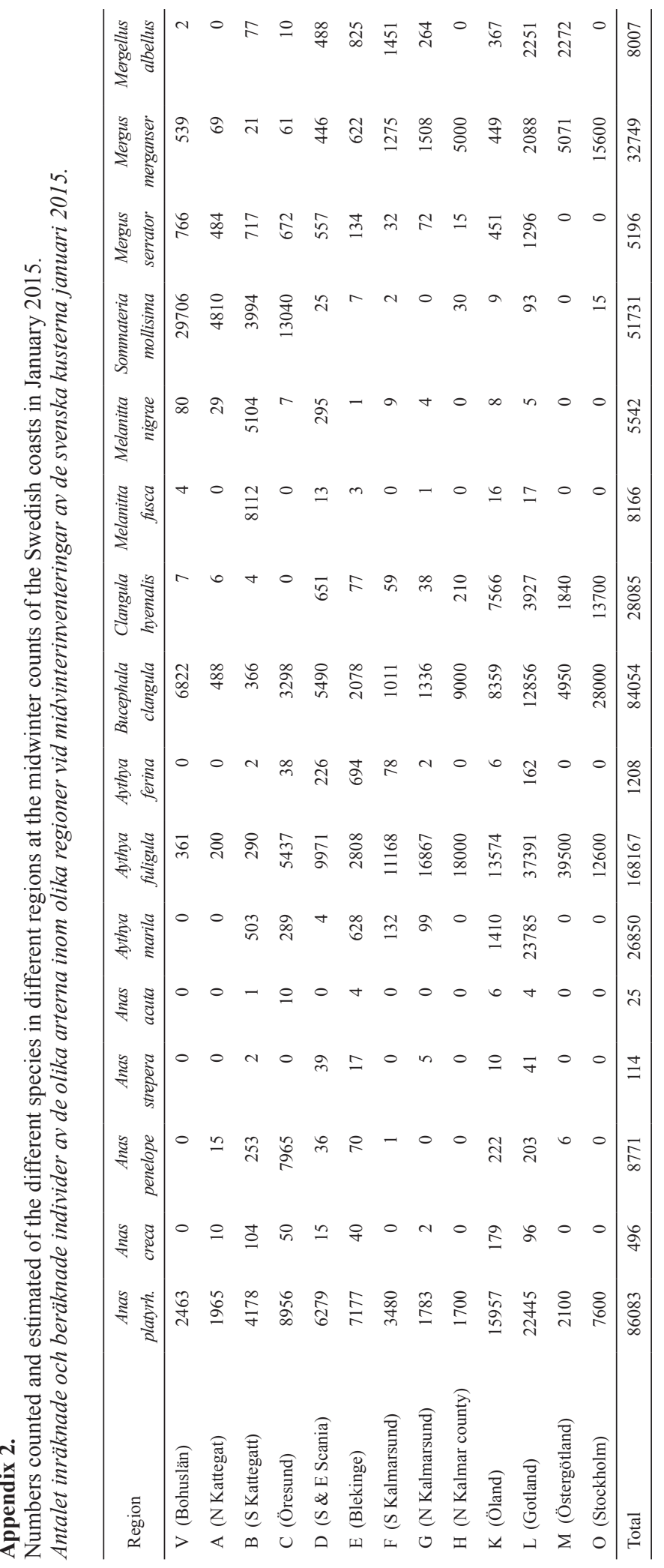




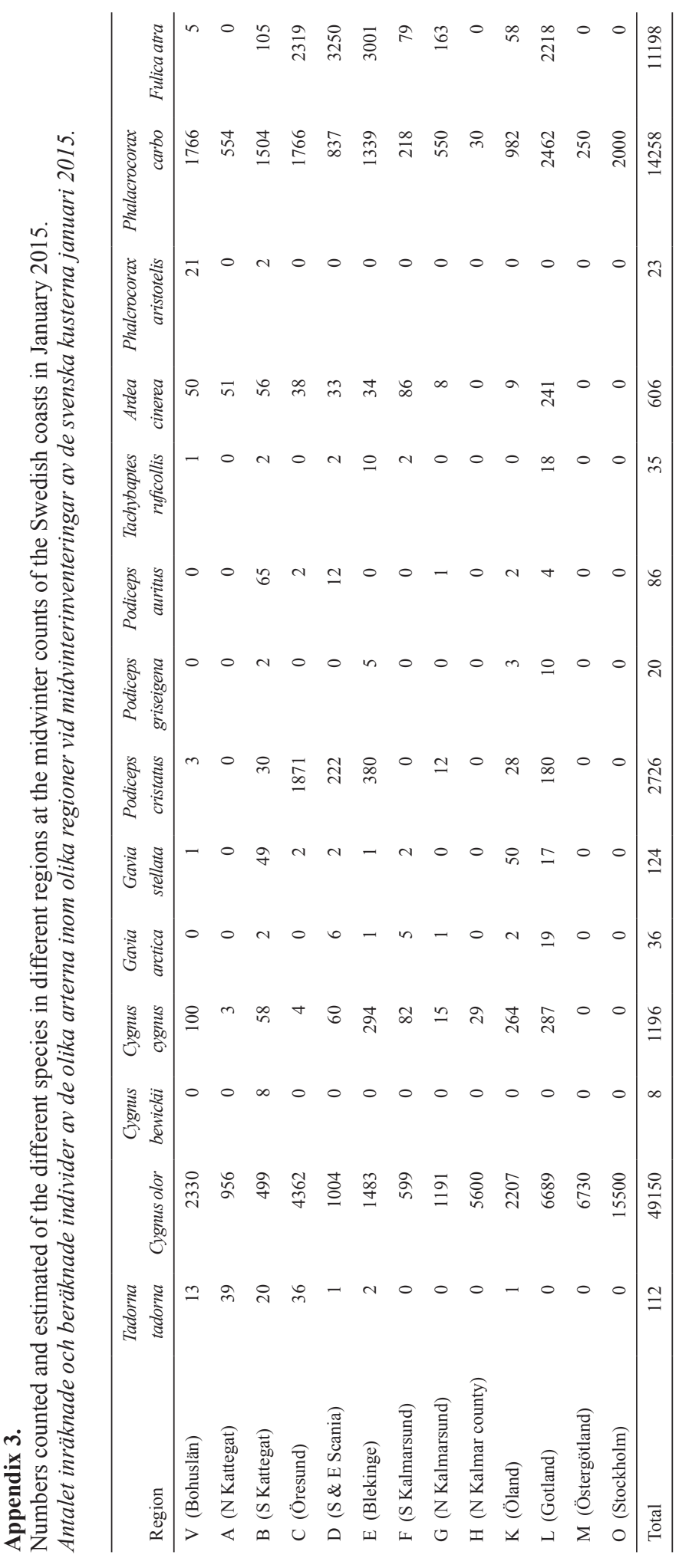


Appendix 4.

Regional trends for 1971-2015 based on the midwinter counts for seven species, all widespread in coastal areas and five also inland. See Figure 1 for Region. For definition of inland waters (Inland, north and south, respectively, see method). Population changes are represented with the slope of the trend line, the corresponding standard error (se) and significance level $(*=\mathrm{p}<0.05, * *=\mathrm{p}<0.01, * * *=\mathrm{p}<0.001, \mathrm{~ns}=$ non-significant). Empty cells denote missing data.

Regionala trender, baserat på data från midvinterräkningarna 1971-2015, för sju vanliga sjöfågelarter, varav fem är vanliga även i inlandet. Se Figur 1 för Region. För förklaring till uppdelningen av inlandsvatten (Inland, south och north, se metod). Populationtrenderna presenteras enligt följande: slope = trendlinjens lutning, se $=$ standardfel och Sign $=$ statistisk signifikans $(*=p<0.05, * *=p<0.01, * * *=p<0.001, n s=$ non-significant $)$. Tomma celler visar att data saknas.

\begin{tabular}{|c|c|c|c|c|c|c|c|c|}
\hline Region & & $\begin{array}{c}\text { Anas } \\
\text { plathyrh. }\end{array}$ & $\begin{array}{l}\text { Aythya } \\
\text { fuligula }\end{array}$ & $\begin{array}{c}\text { Bucephala } \\
\text { clangula. }\end{array}$ & $\begin{array}{l}\text { Mergus } \\
\text { serrator }\end{array}$ & $\begin{array}{c}\text { Mergus } \\
\text { merganser }\end{array}$ & $\begin{array}{l}\text { Cygnus } \\
\text { olor }\end{array}$ & $\begin{array}{c}\text { Fulica } \\
\text { atra }\end{array}$ \\
\hline $\mathrm{V}$ & Slope & 0.996 & 1.106 & 1.033 & 1.006 & 1.022 & 0.983 & 1.078 \\
\hline \multirow[t]{2}{*}{ Bohuslän } & se & 0.008 & 0.066 & 0.005 & 0.005 & 0.008 & 0.005 & 0.061 \\
\hline & Sign & ns & ns & $* * *$ & ns & $* *$ & $* * *$ & ns \\
\hline $\mathrm{AB}$ & Slope & 1.018 & 0.969 & 0.993 & 1.015 & 0.961 & 1.006 & 0.948 \\
\hline \multirow[t]{2}{*}{ Kattegatt } & se & 0.003 & 0.007 & 0.003 & 0.003 & 0.011 & 0.003 & 0.011 \\
\hline & Sign & $* * *$ & $* * *$ & $*$ & $* * *$ & $* * *$ & ns & $* * *$ \\
\hline $\mathrm{C}$ & Slope & 1.019 & 0.989 & 1.019 & 1.064 & 0.982 & 1.028 & 1.010 \\
\hline \multirow[t]{2}{*}{ Öresund } & se & 0.002 & 0.004 & 0.003 & 0.006 & 0.006 & 0.003 & 0.004 \\
\hline & Sign & $* * *$ & $* *$ & $* * *$ & $* * *$ & $* *$ & $* * *$ & $* *$ \\
\hline $\mathrm{D}$ & Slope & 1.044 & 1.008 & 1.014 & 1.031 & 1.002 & 1.025 & 1.031 \\
\hline$S \& E$ & se & 0.003 & 0.004 & 0.002 & 0.003 & 0.004 & 0.003 & 0.006 \\
\hline Scania & Sign & $* * *$ & $*$ & $* * *$ & $* * *$ & ns & $* * *$ & $* * *$ \\
\hline $\mathrm{E}$ & Slope & 1.045 & 1.028 & 1.026 & 1.061 & 1.006 & 1.024 & 1.035 \\
\hline \multirow[t]{2}{*}{ Blekinge } & se & 0.004 & 0.004 & 0.003 & 0.008 & 0.003 & 0.003 & 0.005 \\
\hline & Sign & $* * *$ & $* * *$ & $* * *$ & $* * *$ & ns & $* * *$ & $* * *$ \\
\hline FG & Slope & 1.026 & 1.040 & 1.020 & 1.026 & 1.027 & 1.035 & 1.021 \\
\hline \multirow{2}{*}{$\begin{array}{l}\text { Kalmar- } \\
\text { sund }\end{array}$} & se & 0.003 & 0.007 & 0.004 & 0.007 & 0.004 & 0.003 & 0.014 \\
\hline & Sign & $* * *$ & $* * *$ & $* * *$ & $* * *$ & $* * *$ & $* * *$ & ns \\
\hline HMNO & Slope & 1.013 & 1.023 & 1.067 & 0.986 & 1.021 & 1.014 & 1.005 \\
\hline \multirow{2}{*}{$\begin{array}{l}\text { Part of } \\
\text { east coast }\end{array}$} & se & 0.002 & 0.004 & 0.004 & 0.014 & 0.002 & 0.002 & 0.005 \\
\hline & Sign & $* * *$ & $* * *$ & $* * *$ & ns & $* * *$ & $* * *$ & ns \\
\hline $\mathrm{K}$ & Slope & 1.048 & 1.033 & 1.043 & 1.038 & 1.038 & 1.041 & 1.036 \\
\hline \multirow[t]{2}{*}{ Öland } & se & 0.005 & 0.010 & 0.005 & 0.005 & 0.005 & 0.004 & 0.035 \\
\hline & Sign & $* * *$ & $* * *$ & $* * *$ & $* * *$ & $* * *$ & $* * *$ & ns \\
\hline $\mathrm{L}$ & Slope & 1.037 & 1.033 & 1.037 & 1.002 & 1.030 & 1.055 & 1.021 \\
\hline \multirow[t]{2}{*}{ Gotland } & se & 0.004 & 0.004 & 0.003 & 0.004 & 0.005 & 0.003 & 0.004 \\
\hline & Sign & $* * *$ & $* * *$ & $* * *$ & $\mathrm{~ns}$ & $* * *$ & $* * *$ & $* * *$ \\
\hline \multirow[t]{3}{*}{$\begin{array}{l}\text { I n l a n d, } \\
\text { north }\end{array}$} & Slope & 1.011 & & 1.012 & & 1.005 & 1.005 & 0.998 \\
\hline & se & 0.001 & & 0.002 & & 0.003 & 0.005 & 0.006 \\
\hline & Sign & $* * *$ & & $* * *$ & & ns & ns & ns \\
\hline \multirow[t]{3}{*}{$\begin{array}{l}\text { I n } 1 \text { a n d, } \\
\text { south }\end{array}$} & Slope & 1.004 & & 1.008 & & 0.984 & 1.010 & 1.014 \\
\hline & se & 0.003 & & 0.010 & & 0.010 & 0.009 & 0.016 \\
\hline & Sign & $\mathrm{ns}$ & & $\mathrm{ns}$ & & $\mathrm{ns}$ & ns & ns \\
\hline
\end{tabular}


Appendix 5.
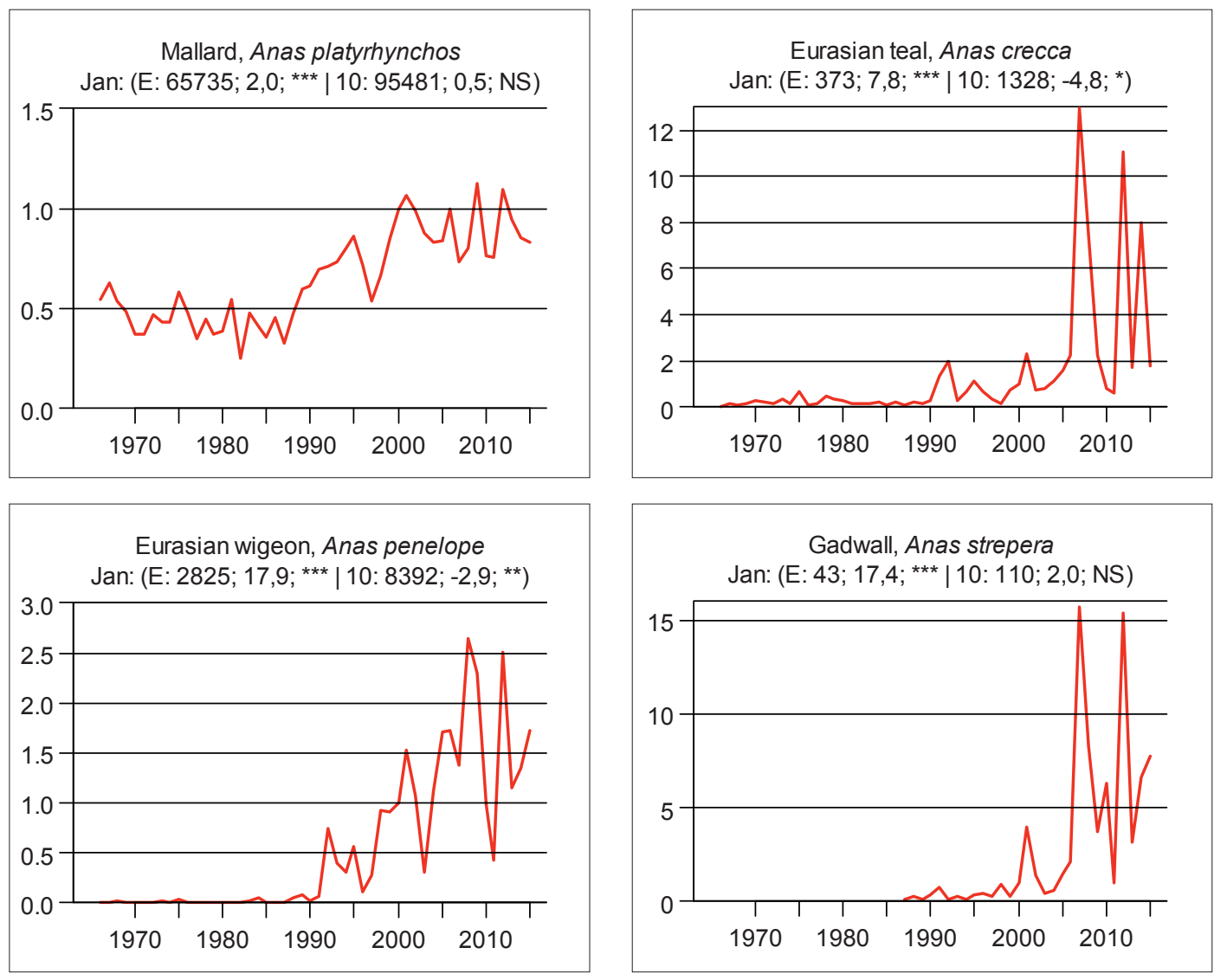

Northern pintail, Anas acuta Jan: (E: 39; 10,5; ** |10: 132; -13,4; ***)

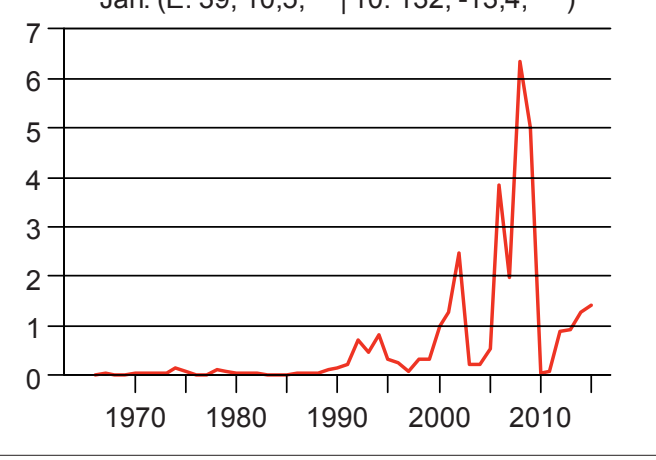

Greater scaup, Aythya marila Jan: (E: 4020; 7,0; *** | 10: 12440; 6,3; ${ }^{* * *}$ )

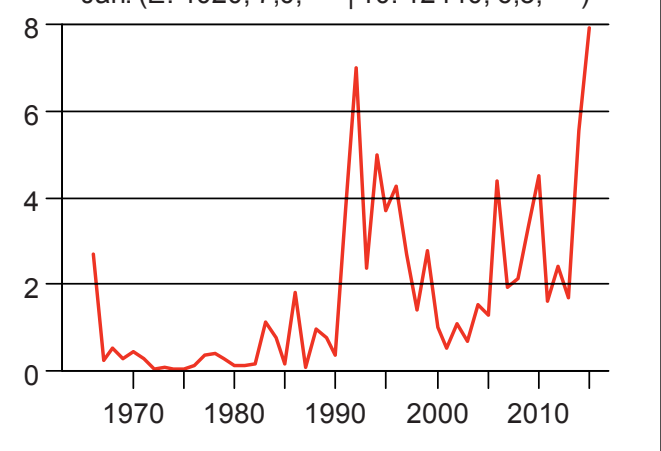


Tufted duck, Aythya fuligula

Jan: (E: 78488; 1,9; *** |10: 111154; -1,6; *)

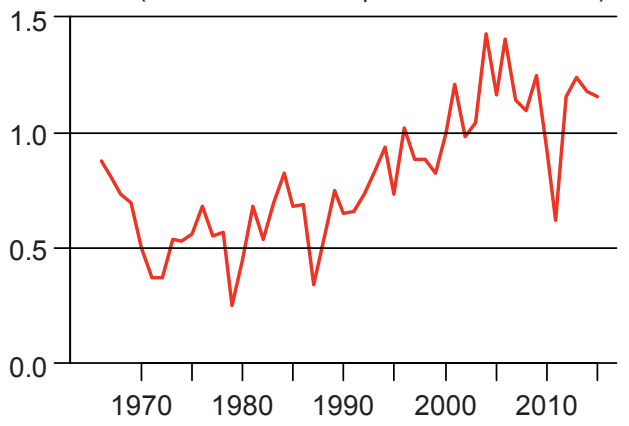

Goldeneye, Bucephala clangula Jan: (E: 20489; 2,2; ***|10: 31878; 1,0; *)

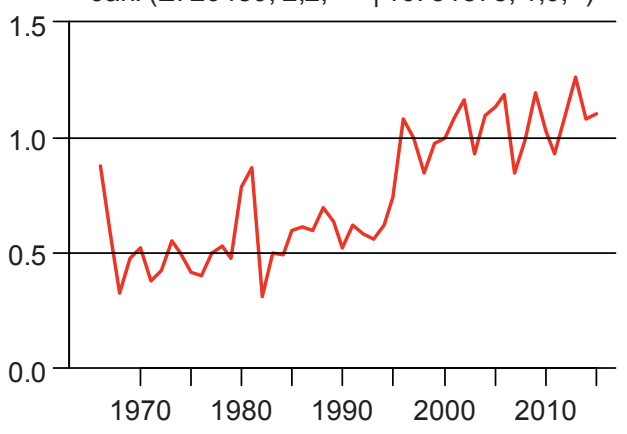

Velvet scoter, Melanitta fusca Jan: (E: 1261; -0,4; NS | 10: 2673; 35,5; $\left.{ }^{* \star *}\right)$

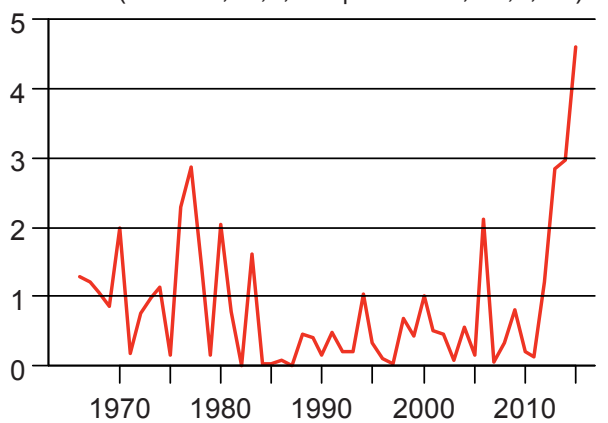

Common pochard, Aythya ferina Jan: (E: 1438; 5,3; *** |10: 2019; -6,7; ***)

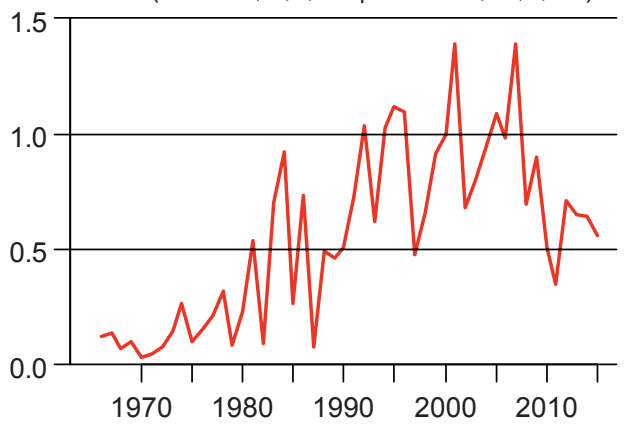

Long-tailed duck, Clangula hyemalis Jan: (E: 18692; -2,0; *** |10: 11085; -2,7; **)

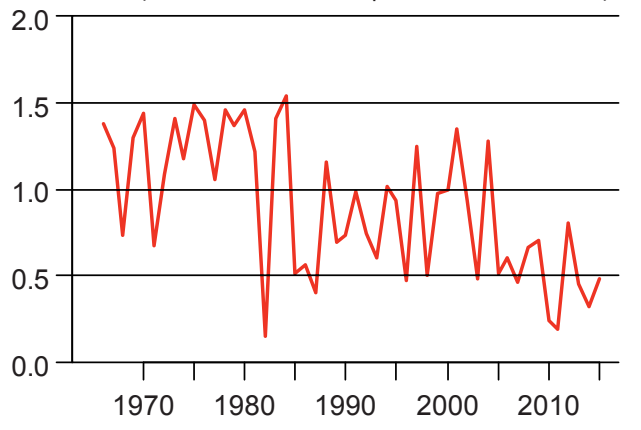

Common scoter, Melanitta nigra Jan: (E: 1020; 6,4; ${ }^{* * *}$ | 10: 2873; 12,5; $\left.{ }^{* * *}\right)$

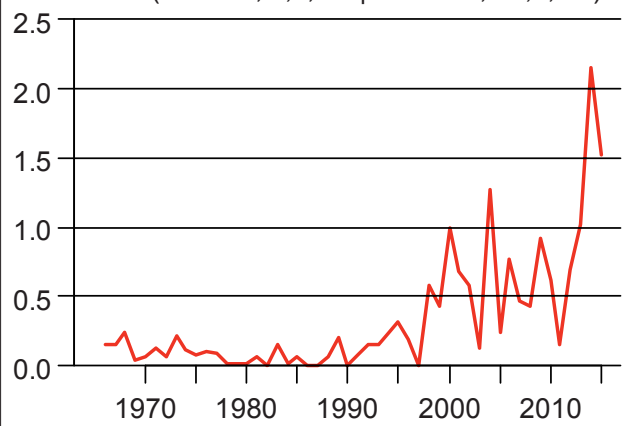



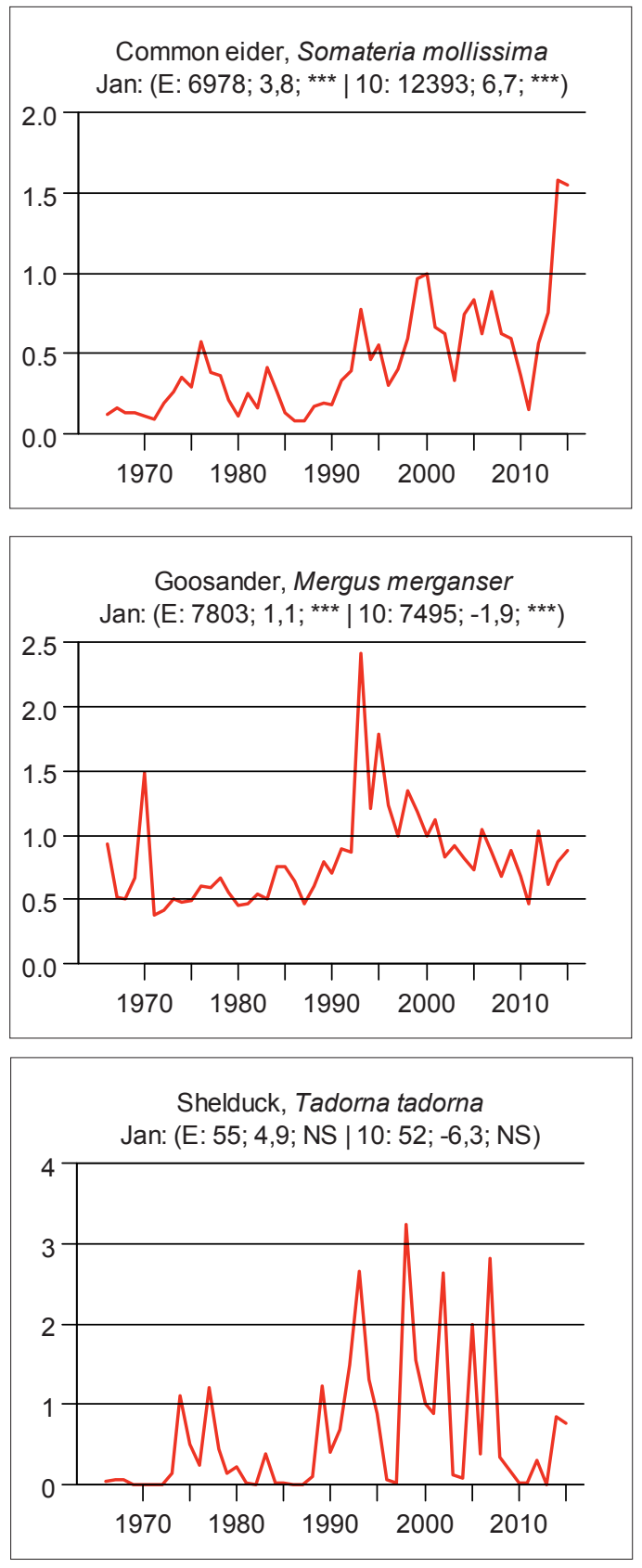

Red-breasted merganser, Mergus serrator Jan: (E: 2771; 2,8; *** | 10: 4577; -3,0; ***)

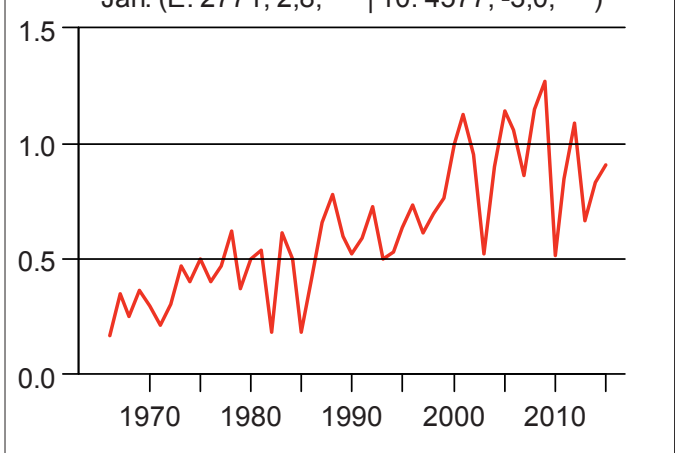

Smew, Mergellus albellus Jan: (E: 1384; 7,2; ** |10: 3706; 2,3; *)

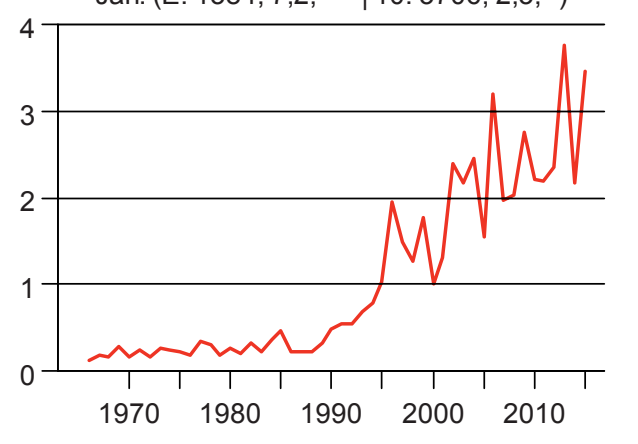

Whooper swan, Cygnus cygnus Jan: (E: 1985; 0,9; *** |10: 2875; -1,7; NS)

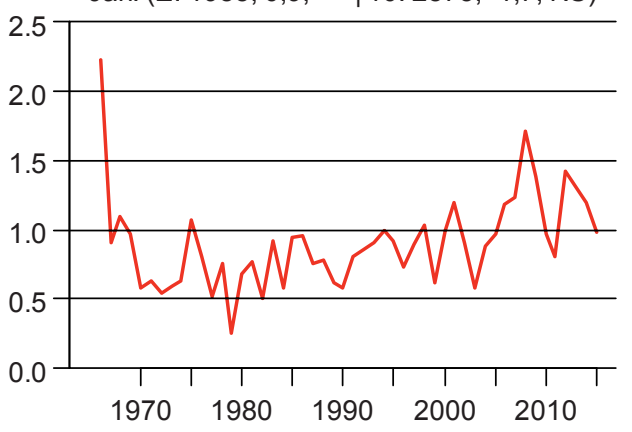



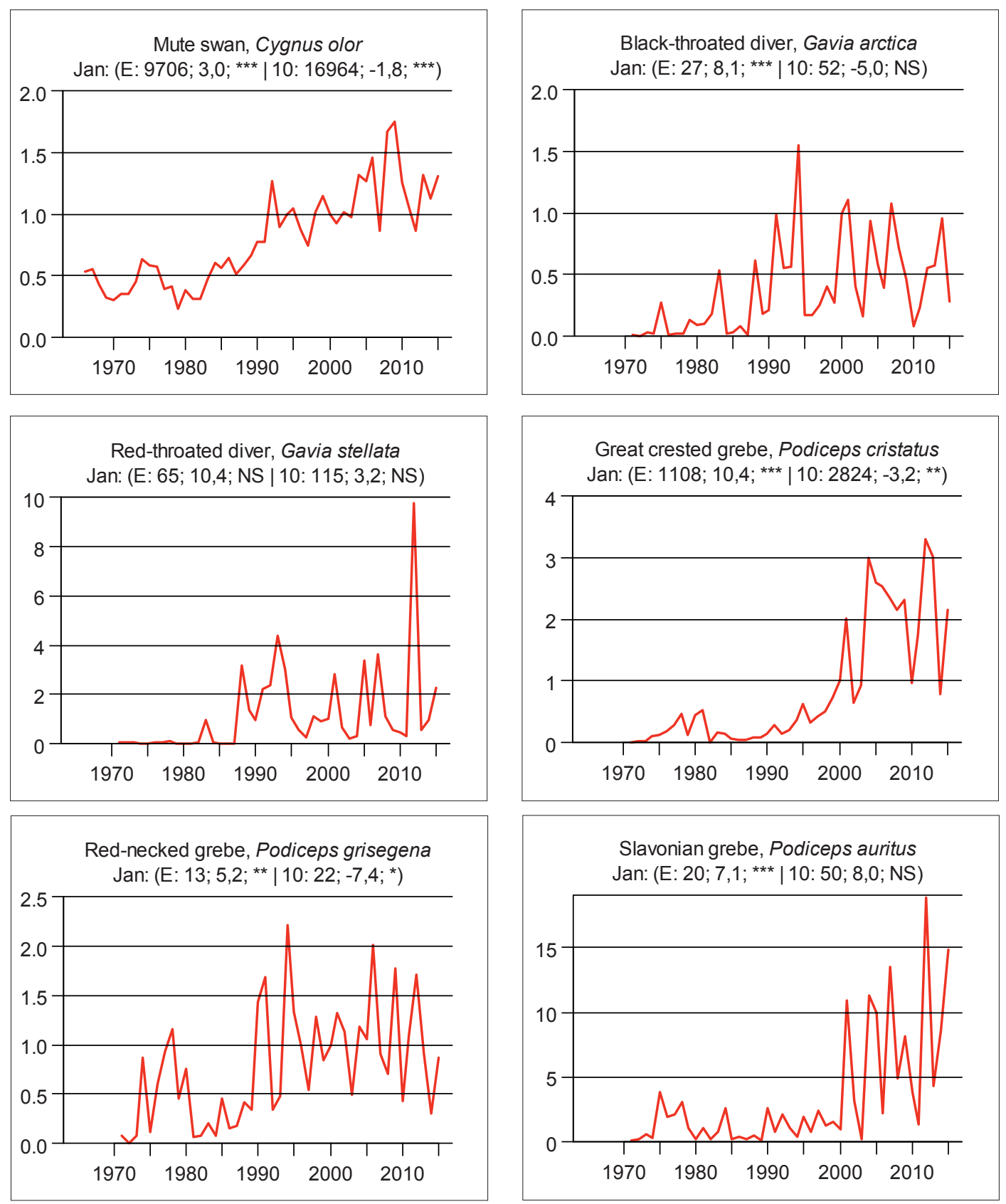

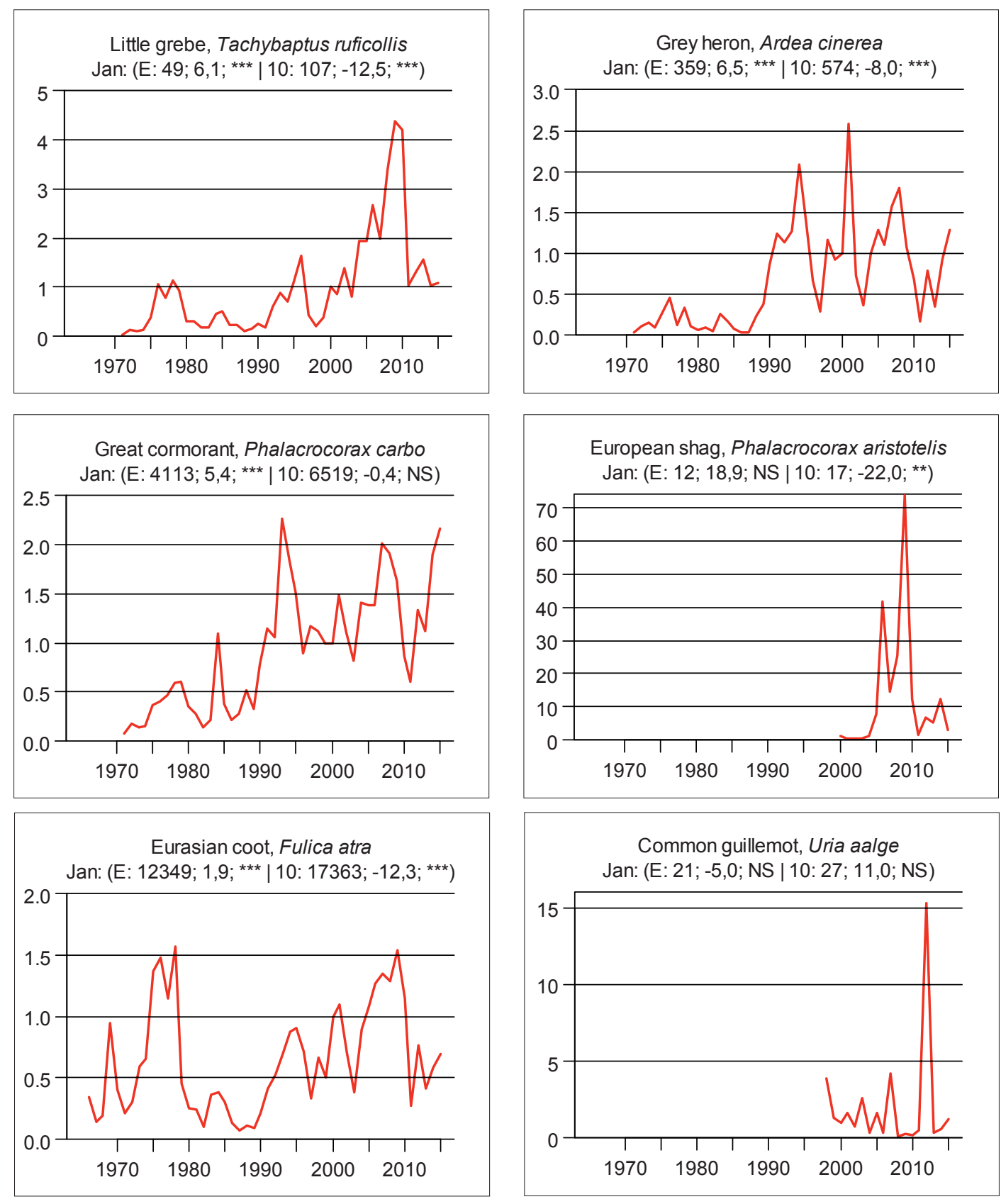

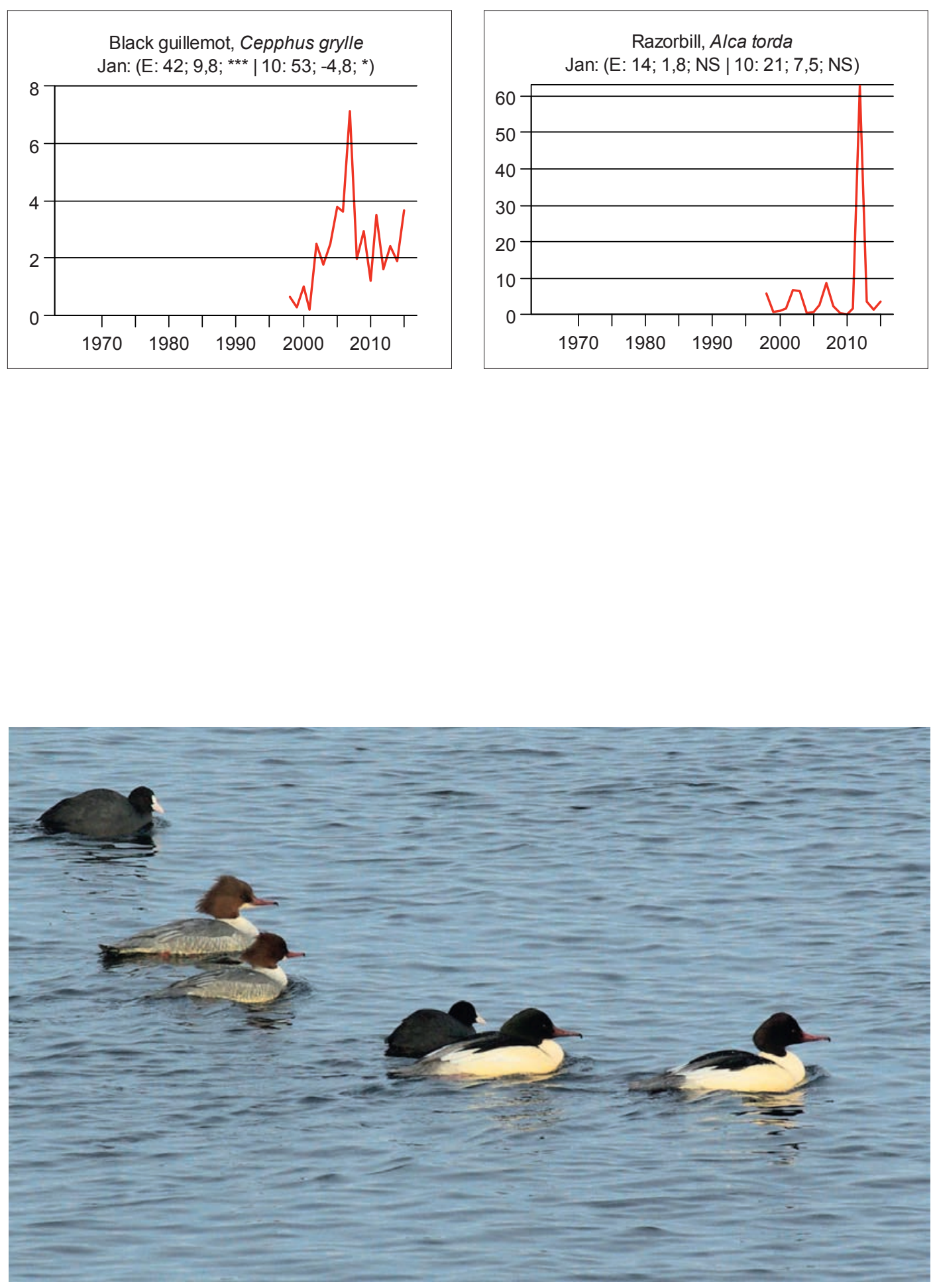

Goosander 